\title{
Decay Heat Calculations for PWR and BWR Assemblies Fueled with Uranium and Plutonium Mixed Oxide Fuel Using Scale
}

September 2011

Prepared by

Brian J. Ade and lan C. Gauld Oak Ridge National Laboratory

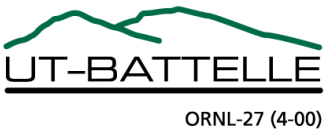




\section{DOCUMENT AVAILABILITY}

Reports produced after January 1, 1996, are generally available free via the U.S. Department of Energy (DOE) Information Bridge.

Web site $\mathrm{http}: / /$ www.osti.gov/bridge

Reports produced before January 1,1996 , may be purchased by members of the public from the following source.

National Technical Information Service

5285 Port Royal Road

Springfield, VA 22161

Telephone 703-605-6000 (1-800-553-6847)

TDD 703-487-4639

Fax 703-605-6900

E-mailinfo@ntis.gov

Web site http://www.ntis.gov/support/ordernowabout.htm

Reports are available to DOE employees, DOE contractors, Energy Technology Data Exchange (ETDE) representatives, and International Nuclear Information System (INIS) representatives from the following source.

Office of Scientific and Technical Information

P.O. Box 62

Oak Ridge, TN 37831

Telephone 865-576-8401

Fax 865-576-5728

E-mail reports@osti.gov

Web site http://www.osti.gov/contact.html

This report was prepared as an account of work sponsored by an agency of the United States Government. Neither the United States Government nor any agency thereof, nor any of their employees, makes any warranty, express or implied, or assumes any legal liability or responsibility for the accuracy, completeness, or usefulness of any information, apparatus, product, or process disclosed, or represents that its use would not infringe privately owned rights. Reference herein to any specific commercial product, process, or service by trade name, trademark, manufacturer, or otherwise, does not necessarily constitute or imply its endorsement, recommendation, or favoring by the United States Government or any agency thereof. The views and opinions of authors expressed herein do not necessarily state or reflect those of the United States Government or any agency thereof. 


\title{
DECAY HEAT CALCULATIONS FOR PWR AND BWR ASSEMBLIES FUELED WITH URANIUM AND PLUTONIUM MIXED OXIDE FUEL USING SCALE
}

\author{
Brian J. Ade \\ Ian C. Gauld
}

Date Published: September 2011

\author{
Prepared by \\ OAK RIDGE NATIONAL LABORATORY \\ Oak Ridge, Tennessee 37831-6283 \\ managed by \\ UT-BATTELLE, LLC \\ for the \\ U.S. DEPARTMENT OF ENERGY \\ under contract DE-AC05-00OR22725
}





\section{CONTENTS}

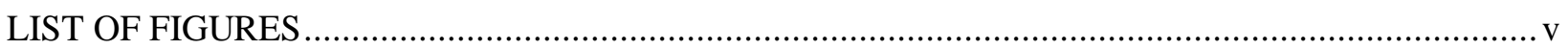

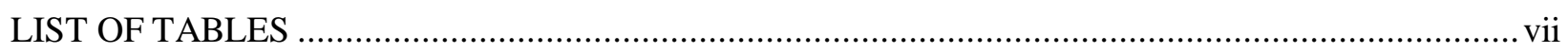

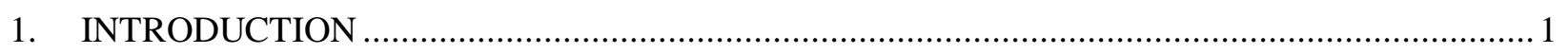

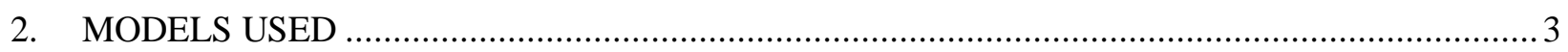

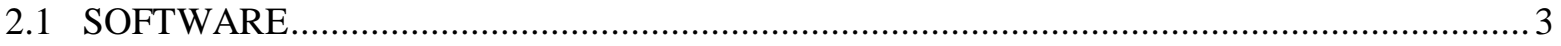

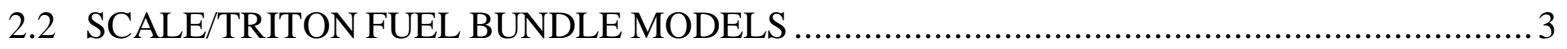

2.2.1 PWR Fuel Bundle Model.......................................................................... 4

2.2.2 BWR Fuel Bundle Model ................................................................................ 5

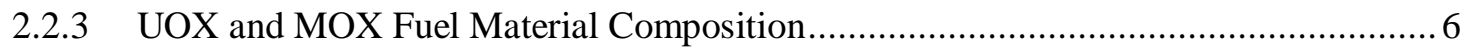

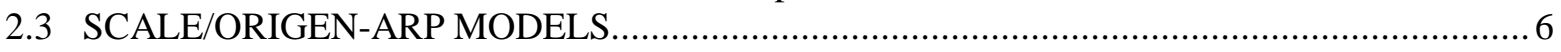

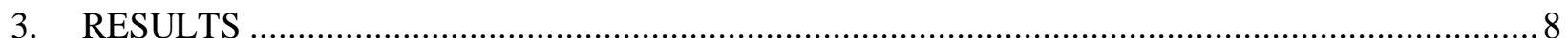

3.1 CALCULATION OF EQUIVALENT PLUTONIUM CONTENT …............................

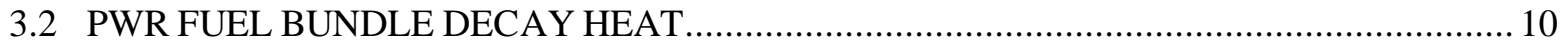

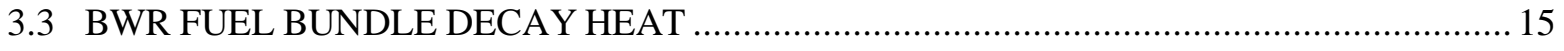

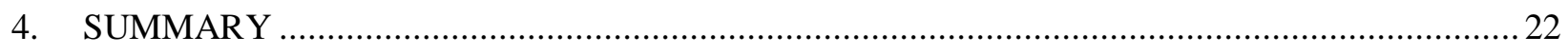

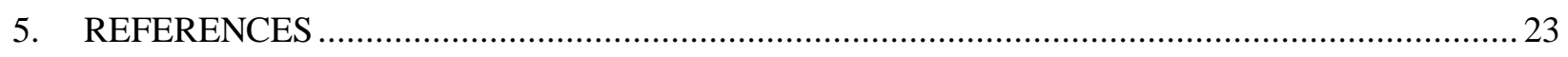

APPENDIX A DETAILED DATA REGARDING THE STORAGE OF WG-MOX FUEL ................ A-1

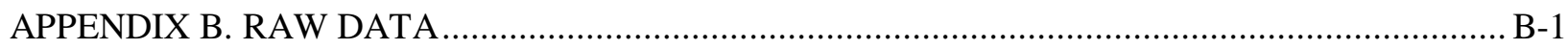





\section{LIST OF FIGURES}

Figure

Page

1 SCALE/NEWT $1 / 4$ assembly model of the PWR $17 \times 17$ fuel bundle. …............................... 4

SCALE/NEWT model of the BWR $7 \times 7$ fuel bundle.

Interpolated $\mathrm{k}_{\mathrm{eff}}$ as a function of burnup for $4.25 \%$ enriched $\mathrm{UO}_{2}$ and equivalent $\mathrm{RG}-\mathrm{Pu}$ and WG-Pu for the PWR fuel bundle.

Interpolated $\mathrm{k}_{\mathrm{eff}}$ as a function of burnup for $4.25 \%$ enriched $\mathrm{UO}_{2}$ and equivalent $\mathrm{RG}-\mathrm{Pu}$

and WG-Pu for the BWR fuel bundle...................................................................... 9

PWR fuel bundle decay heat as a function of time after discharge at $35 \mathrm{GWd} / \mathrm{MTHM} \ldots \ldots . . . .11$

PWR fuel bundle decay heat as a function of time after discharge at $40 \mathrm{GWd} / \mathrm{MTHM}$......... 11

PWR fuel bundle decay heat as a function of time after discharge at $45 \mathrm{GWd} / \mathrm{MTHM}$......... 12

PWR fuel bundle decay heat as a function of time after discharge at 50 GWd/MTHM........ 12

Decay heat ratio as a function of time for RG-MOX for the first 10 days after

discharge (PWR).

10 Decay heat ratio as a function of time for WG-MOX for the first 10 days after

discharge (PWR).

11 Decay heat ratio as a function of time for RG-MOX for the first 15,000 days after

discharge (PWR).

12 Decay heat ratio as a function of time for WG-MOX for the first 15,000 days after

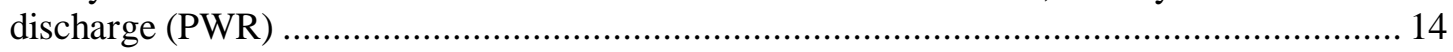

13 BWR fuel bundle decay heat as a function of time after discharge at $35 \mathrm{GWd}$ /MTHM. ...... 16

14 BWR fuel bundle decay heat as a function of time after discharge at $40 \mathrm{GWd}$ /MTHM....... 17

15 BWR fuel bundle decay heat as a function of time after discharge at $45 \mathrm{GWd} / \mathrm{MTHM}$........ 17

16 BWR fuel bundle decay heat as a function of time after discharge at $50 \mathrm{GWd} / \mathrm{MTHM}$........ 18

17 Decay heat ratio as a function of time for RG-MOX for the first 10 days after discharge

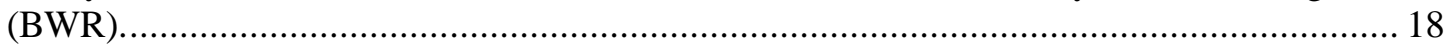

18 Decay heat ratio as a function of time for WG-MOX for the first 10 days after discharge (BWR).

19 Decay heat ratio as a function of time for RG-MOX for the first 15,000 days after discharge (BWR).

20 Decay heat ratio as a function of time for WG-MOX for the first 15,000 days after discharge (BWR). 



\section{LIST OF TABLES}

Table

Page

$1 \quad$ PWR $17 \times 17$ fuel bundle dimensions (centimeters) ................................................... 4

$2 \quad$ BWR $7 \times 7$ fuel bundle dimensions (centimeters) .................................................. 5

3 Isotopic fractions of uranium and plutonium in typical WG- and RG-MOX fuel

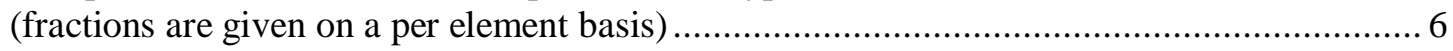

$4 \quad$ Decay heat ratios for the PWR fuel bundle at selected cooling time................................. 15

5 RG-MOX and WG-MOX crossover points for different discharge burnup for the PWR ...... 15

6 Decay heat ratios for the BWR fuel bundle at selected points ........................................20

7 RG-MOX and WG-MOX crossover points for different discharge burnup for the BWR ...... 21 



\section{INTRODUCTION}

In currently operating commercial nuclear power plants (NPP), there are two main types of nuclear fuel, low enriched uranium (LEU) fuel, and mixed-oxide uranium-plutonium (MOX) fuel. The LEU fuel is made of pure uranium dioxide $\left(\mathrm{UO}_{2}\right.$ or $\left.\mathrm{UOX}\right)$ and has been the fuel of choice in commercial light water reactors (LWRs) for a number of years. Naturally occurring uranium contains a mixture of different uranium isotopes, primarily, ${ }^{235} \mathrm{U}$ and ${ }^{238} \mathrm{U}$. ${ }^{235} \mathrm{U}$ is a fissile isotope, and will readily undergo a fission reaction upon interaction with a thermal neutron. ${ }^{235} \mathrm{U}$ has an isotopic concentration of $0.71 \%$ in naturally occurring uranium. For most reactors to maintain a fission chain reaction, the natural isotopic concentration of ${ }^{235} \mathrm{U}$ must be increased (enriched) to a level greater than $0.71 \%$. Modern nuclear reactor fuel assemblies contain a number of fuel pins potentially having different ${ }^{235} \mathrm{U}$ enrichments varying from $\sim 2.0 \%$ to $\sim 5 \%$ enriched in ${ }^{235}$ U. Currently in the United States (US), all commercial nuclear power plants use $\mathrm{UO}_{2}$ fuel.

In the rest of the world, $\mathrm{UO}_{2}$ fuel is still commonly used, but MOX fuel is also used in a number of reactors. MOX fuel contains a mixture of both $\mathrm{UO}_{2}$ and $\mathrm{PuO}_{2}$. Because the plutonium provides the fissile content of the fuel, the uranium used in MOX is either natural or depleted uranium. $\mathrm{PuO}_{2}$ is added to effectively replace the fissile content of ${ }^{235} \mathrm{U}$ so that the level of fissile content is sufficiently high to maintain the chain reaction in an LWR. Both reactor-grade and weapons-grade plutonium contains a number of fissile and non-fissile plutonium isotopes, with the fraction of fissile and non-fissile plutonium isotopes being dependent on the source of the plutonium. While only RG plutonium is currently used in MOX, there is the possibility that WG plutonium from dismantled weapons will be used to make MOX for use in US reactors.

Reactor-grade plutonium in MOX fuel is generally obtained from reprocessed irradiated nuclear fuel, whereas weapons-grade plutonium is obtained from decommissioned nuclear weapons material and thus has a different plutonium (and other actinides) concentration. Using MOX fuel instead of UOX fuel has potential impacts on the neutronic performance of the nuclear fuel and the design of the nuclear fuel must take these differences into account. Each of the plutonium sources (RG and WG) has different implications on the neutronic behavior of the fuel because each contains a different blend of plutonium nuclides. The amount of heat and the number of neutrons produced from fission of plutonium nuclides is different from fission of ${ }^{235} \mathrm{U}$. These differences in UOX and MOX do not end at discharge of the fuel from the reactor core - the short- and long-term storage of MOX fuel may have different requirements than UOX fuel because of the different discharged fuel decay heat characteristics.

The research documented in this report compares MOX and UOX fuel during storage and disposal of the fuel by comparing decay heat rates for typical pressurized water reactor (PWR) and boiling water reactor (BWR) fuel assemblies with and without weapons-grade (WG) and reactor-grade (RG) MOX fuel. 


\section{MODELS USED}

\subsection{SOFTWARE}

In order complete this research, the SCALE code system was applied. Specifically, the SCALE/TRITON sequence (DeHart \& Bowman, 2011) was used for depletion calculations and SCALE/ORIGEN-ARP (Gauld, Radulescu, Ilas, Murphy, Williams, \& Wiarda, 2011) was used for calculation of decay heat rates at specific initial fuel composition and discharge burnup level.

SCALE/TRITON is a code sequence developed within the framework of the SCALE code system that automates 1-D resonance self-shielding of problem-dependent cross sections (Williams, 2011), 2-D and 3-D generalized transport calculations, and isotopic depletion in order to perform 2-D and 3-D depletion calculations.

TRITON was originally built around SCALE/NEWT, an arbitrary-geometry deterministic neutron transport solver, which provides the capability to perform rigorous deterministic transport analysis for a wide variety of problem types; however, the modular nature of SCALE/TRITON has enabled extension of depletion capabilities to use 3-D stochastic Monte Carlo solutions via SCALE/KENO V.a and SCALE/KENO-VI. Used in conjunction with SCALE/NEWT, SCALE/TRITON is able to perform 2-D lattice calculations for nontraditional lattice designs, including hexagonal arrays and non-lattice configurations. Both SCALE/KENO codes offer powerful 3-D geometric representations for depletion calculations. The treatment of neutron transport available within SCALE/NEWT and SCALE/KENO, coupled with the accuracy of SCALE/ORIGEN-S depletion capabilities and SCALE resonance selfshielding calculations within SCALE/TRITON-driven lattice physics analyses, provides a rigorous approach for calculation of cross sections and isotopic depletion source terms for fuel designs.

SCALE/ORIGEN-ARP is a SCALE depletion analysis tool used to perform point-depletion calculations with the SCALE/ORIGEN-S code using problem-dependent cross sections. Problem-dependent cross section libraries are generated using the ARP (Automatic Rapid Processing) module using an interpolation algorithm that operates on pre-generated libraries created for a range of fuel properties and operating conditions. Methods are provided in SCALE to generate these libraries using 1-, 2-, and 3-D transport codes. The interpolation of cross sections for UOX and MOX fuels may be performed for the variables burnup, enrichment, and moderator density. Interpolation may also be performed for flux-based calculations using neutron fluence as the interpolation parameter. The Windows graphical user interface for SCALE/ ORIGEN-ARP, written in Visual C++, greatly facilitates the creation of input files for the ARP and ORIGEN-S codes. SCALE/ ORIGEN-ARP interacts directly with the SCALE code system to execute the input files in the required sequence and executes a post-processor to extract desired quantities.

Instead of using the cross section libraries that are distributed with ORIGEN-ARP, new libraries were generated in order to maintain consistency between the fuel isotopic composition for the PWR and BWR models using SCALE/TRITON. The two models chosen for this analysis were a $17 \times 17$ PWR fuel bundle and a $7 \times 7$ BWR fuel bundle.

\subsection{SCALE/TRITON FUEL BUNDLE MODELS}

The two fuel bundle models were chosen to represent common fuel bundles used in commercial nuclear power reactors. For the PWR, the ORIGEN-ARP template for a Westinghouse $17 \times 17$ fuel bundle was chosen from the SCALE distribution. For the BWR, a previously developed $7 \times 7$ BWR fuel assembly model for analysis of Peach Bottom Unit 2 was modified to suit the specific needs of this research (Larsen, 1978). The $7 \times 7$ BWR fuel bundle is an older design. More modern BWR bundles are 10×10, but 
the model does capture the different spectral effects that are common to BWR fuel bundles due to boiling coolant.

For both the PWR and BWR fuel bundles, SCALE/CENTRM was used for cross section processing. The fuel material composition of these models was varied, as outlined in Sect. 2.2.3, in order to obtain ORIGEN-ARP cross section libraries at varied ${ }^{235} \mathrm{U}$ enrichment in UOX fuel and varied plutonium content in MOX fuel.

\subsubsection{PWR Fuel Bundle Model}

As previously stated, the Westinghouse $17 \times 17$ PWR fuel assembly model was taken from the ORIGENARP model templates, which can be found under data/arplibs/templates in the SCALE installation directory (Gauld, 2003). The major modeling dimensions for this lattice are shown in Table 1.

Table 1. PWR 17×17 fuel bundle dimensions (centimeters)

\begin{tabular}{lr} 
Assembly pitch & 21.40300 \\
\hline Fuel rod pitch & 1.25900 \\
Fuel pellet radius & 0.40250 \\
Fuel gap radius & 0.41100 \\
Fuel clad radius & 0.47500 \\
Guide tube inner radius & 0.57175 \\
Guide tube outer radius & 0.61210 \\
\hline
\end{tabular}

In this model, the instrument tube is assumed to have the same dimensions as the guide tube. No intraassembly gap has been modeled, and no burnable absorbers have been used in the model. The PWR model uses a nominal moderator density of $0.72 \mathrm{~g} / \mathrm{cm}^{3}$ with a soluble boron concentration of $600 \mathrm{ppm}$ by weight. Detailed fuel material definition is given in Sect. 2.2.3. The clad, guide tube, and instrument tube material is Zircalloy-4. A SCALE/NEWT figure of the PWR model is shown in Fig. 1.

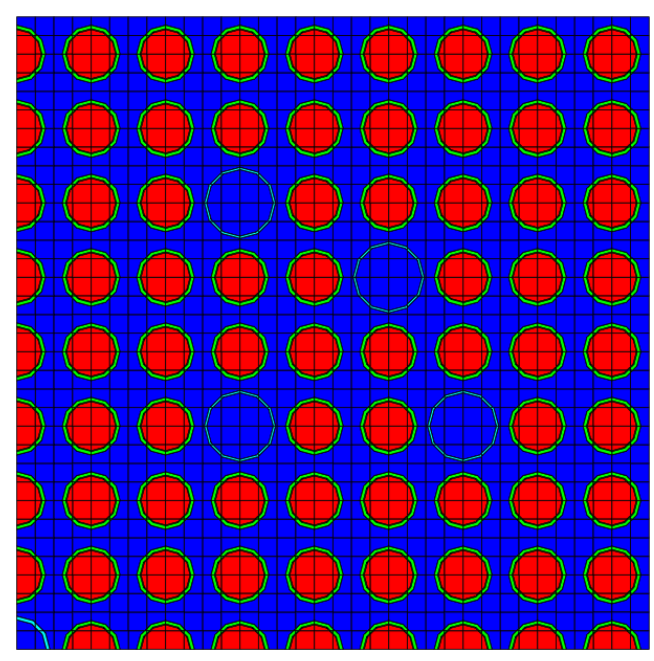

Fig. 1. SCALE/NEWT $1 / 4$ assembly model of the PWR 17×17 fuel bundle. 


\subsubsection{BWR Fuel Bundle Model}

The BWR model was modified from a previously developed model for analysis of Peach Bottom Unit 2. This model is of a General Electric design $7 \times 7$ fuel assembly. The major model dimensions and parameters are shown in Table 2.

Table 2. BWR $7 \times 7$ fuel bundle dimensions (centimeters)

\begin{tabular}{lc} 
Assembly pitch & 15.24000 \\
\hline Fuel rod pitch & 1.87452 \\
\hline Fuel pellet radius & 0.06185 \\
Fuel gap radius & 0.06337 \\
\hline Fuel clad radius & 0.07150 \\
\hline Water rod inner diameter & N/A \\
\hline Water rod outer diameter & N/A \\
Channel box outer dimension & 1.38125 \\
\hline Channel box thickness & 0.02032 \\
Channel box corner inner radius & 0.09652 \\
\hline Lattice offset & 0.02375 \\
\hline
\end{tabular}

No burnable absorbers have been used in the model. The BWR model uses an in-channel moderator density of $0.457211 \mathrm{~g} / \mathrm{cm}^{3}$ (40\% void) and an out-channel moderator density of $0.738079 \mathrm{~g} / \mathrm{cm}^{3}(0 \%$ void). Detailed fuel material definition is given in Sect. 2.2.3. The clad material is Zircalloy-2, and the channel box material is Zircalloy-4. There are seven spacer grids per fuel bundle composed of a mixture of Zircalloy-4 and Inconel whose material has been mixed with the cladding material to conserve the mass of the spacer grids. The channel box has rounded corners with an inner radius of $0.9652 \mathrm{~cm}$. The lattice offset in Table 2 describes the distance that the center of the fuel bundle is offset from the center of the model; the lattice office is common in BWR fuel bundle models to ensure sufficient clearance for control blade insertion. The SCALE/NEWT fuel assembly diagram of the BWR model is shown in Fig. 2.

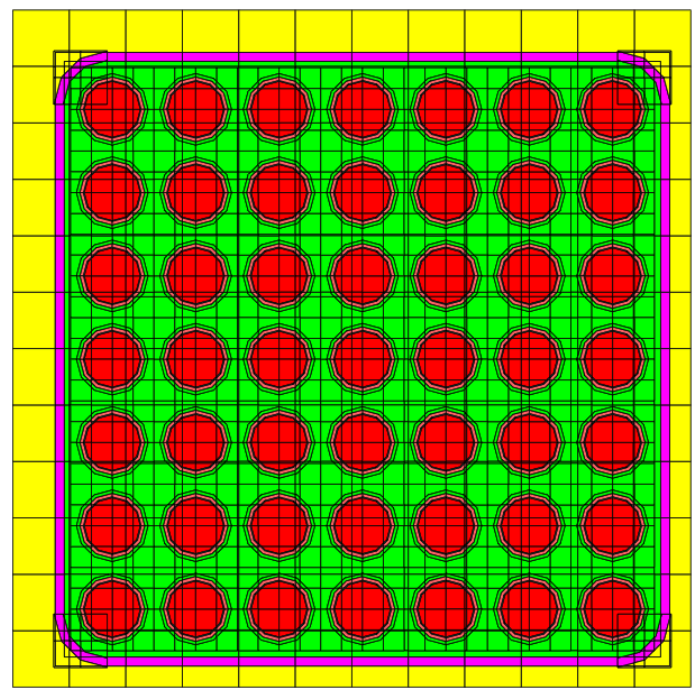

Fig. 2. SCALE/NEWT model of the BWR $7 \times 7$ fuel bundle. 


\subsubsection{UOX and MOX Fuel Material Composition}

The initial UOX fuel was assumed to be composed of only ${ }^{235} U$ and ${ }^{238} U$. Although trace amounts of ${ }^{234} U$ and ${ }^{236} \mathrm{U}$ are typically present in fresh reactor fuel, these isotopes are ignored for this analysis, as their influence on the decay will be negligible compared to ${ }^{235} \mathrm{U}$ and ${ }^{238} \mathrm{U}$ and their associated irradiation products. ORIGEN-ARP libraries were generated for ${ }^{235} \mathrm{U}$ enrichments of 2.0, 3.0, 4.0, and 5.0\%.

MOX fuel compositions for both RG and WG were obtained from the MOX Fuel Design Report by Framatome ANP, Inc., to the US NRC (Framatome ANP, Inc., 2003). The isotopic fractions of uranium and plutonium in RG-MOX and WG-MOX are given in Table 3. In the report, isotopic compositions of plutonium are given only for ${ }^{239} \mathrm{Pu},{ }^{240} \mathrm{Pu},{ }^{241} \mathrm{Pu}$, and ${ }^{241} \mathrm{Pu}$ with a balance of ${ }^{238} \mathrm{Pu}$; the ${ }^{238} \mathrm{Pu}$ isotopic fraction has been added to Table 3. As shown in Table 3, the major difference between RG-MOX and WG-MOX is that the former has a significant fraction of ${ }^{240} \mathrm{Pu}$ and ${ }^{241} \mathrm{Pu}$ that is replaced by ${ }^{239} \mathrm{Pu}$ in WGMOX.

Table 3. Isotopic fractions of uranium and plutonium in typical WG- and RG-MOX fuel (fractions are given on a per element basis) ${ }^{a}$

\begin{tabular}{crr}
\hline & \multicolumn{2}{c}{ Isotopic fraction } \\
\cline { 2 - 3 } Isotope & RG-MOX & \multicolumn{1}{c}{ WG-MOX } \\
\hline${ }^{235} \mathrm{U}$ & $0.25 \%$ & $0.25 \%$ \\
${ }^{238} \mathrm{U}$ & $99.75 \%$ & $99.75 \%$ \\
\hline${ }^{238} \mathrm{Pu}$ & $0.90 \%$ & $0.05 \%$ \\
${ }^{239} \mathrm{Pu}$ & $67.40 \%$ & $92.50 \%$ \\
${ }^{240} \mathrm{Pu}$ & $21.10 \%$ & $6.90 \%$ \\
${ }^{241} \mathrm{Pu}$ & $7.60 \%$ & $0.50 \%$ \\
${ }^{242} \mathrm{Pu}$ & $3.00 \%$ & $0.05 \%$ \\
\hline
\end{tabular}

${ }^{a}$ Source: Framatome ANP, Inc, 2003.

A user may input an exact fuel composition in ORIGEN-ARP, but in order to calculate cross sections for a specified fuel composition, ORIGEN-ARP requires bounding points to perform an interpolation to the exact fuel composition. In order to cover a range of different ${ }^{235} \mathrm{U}$ enrichments in UOX fuel and a range of different plutonium content in MOX fuel, a number of separate SCALE/TRITON transport calculations are needed to generate the required cross section libraries for ORIGEN-ARP. As previously stated, for the UOX fuel, ORIGEN-ARP libraries were created using ${ }^{235} \mathrm{U}$ enrichments of 2.0, 3.0, 4.0, and 5.0\%. For the MOX fuel libraries, the ${ }^{235} \mathrm{U}$ enrichment was held constant at $0.25 \%$ while the ratio of uranium to plutonium in the MOX was varied between 2.0 and 10.0\%. For all MOX fuel calculations, ORIGEN-ARP cross sections libraries were generated at 2.0, 3.0, 4.0, 5.0, 6.0, 7.0, 8.0, 9.0, and 10.0\% by weight plutonium in the fuel.

Using the cross section libraries generated, it is possible to perform an ORIGEN-ARP calculation for UOX at any enrichment between $2.0 \%$ and $5.0 \%$, and at and plutonium content between $2.0 \%$ and $10.0 \%$.

\subsection{SCALE/ORIGEN-ARP MODELS}

All SCALE/ORIGEN-ARP models are identical, with the exception of the fuel composition and the cross section library used. In order to make a valid comparison of decay heat between UOX, RG-MOX, and WG-MOX, a roughly "equivalent" composition is needed. Given a certain bundle-average enrichment for 
UOX fuel, an equivalent composition of MOX should be chosen such that fuel bundle performs similarly to a UOX fuel bundle in the reactor. In practice, a MOX fuel bundle performs differently from a UOX fuel bundle in a reactor due mainly to the increased thermal fission cross section of ${ }^{239} \mathrm{Pu}$. For this study, a procedure to determine the "equivalent" RG or WG plutonium content in the fuel was performed and is outlined in the results section. The results of this study were used to determine the initial $\mathrm{PuO}_{2}$ content in the MOX fuel for each of the ORIGEN-ARP input files for UOX, RG-MOX, and WG-MOX fuel.

Each ORIGEN-ARP input file simulates three cycles of reactor operation with 30 days of downtime between cycles. Each irradiation cycle is 540 days (18 months) using a constant specific power during each irradiation. For each fuel assembly, the specific power is held constant during the calculation but varies between calculations, resulting in discharge burnup points of 35, 40, 45, and $50 \mathrm{GWd} / \mathrm{MTHM}$. During the final decay step, the thermal power is calculated at 70 discrete points after discharge up to 52.9 years. During the final decay, the length of each decay step is varied so that fine time steps are taken at the start of the decay and longer time steps are taken toward the end of the decay. 


\section{RESULTS}

The results herein outline the overall decay heat generated from a BWR or PWR fuel assembly fueled with UOX, RG-MOX, or WG-MOX. The data presented only give the overall decay heat generated and the ratio of the decay heat compared to and equivalent UOX fuel assembly. Detailed isotopic contributors to the decay heat have been omitted from this document.

\subsection{CALCULATION OF EQUIVALENT PLUTONIUM CONTENT}

In order to accurately compare decay heat between UOX and MOX fuel, the approximate "equivalent" plutonium content should be calculated. For this study, the equivalent plutonium content is defined as the content of $\mathrm{RG}$ or $\mathrm{WG} \mathrm{PuO}_{2}$ that will result in equivalent bundle reactivity integrated over burnup when compared to a certain assembly average ${ }^{235} \mathrm{U}$ enrichment in UOX fuel. The first step is to assume a typical assembly average ${ }^{235} \mathrm{U}$ enrichment. For this study, a fuel bundle average enrichment of $4.25 \%$ was assumed for UOX fuel. An average discharge burnup of $40 \mathrm{GWd} / \mathrm{MTHM}$ and a linear trend in $\mathrm{k}_{\text {inf }}$ as a function of burnup were also assumed (a reasonable approximation for assemblies that do not contain burnable absorbers). Given the aforementioned assumptions, the RG-MOX and WG-MOX $\mathrm{k}_{\text {inf }}$ trajectory should cross the UOX $\mathrm{k}_{\text {inf }}$ trajectory at $20 \mathrm{GWd} / \mathrm{MTHM}$.

SCALE/TRITON calculations were run for $2.0-5.0 \%{ }^{235} \mathrm{U}$ enrichment for UOX fuel and $2.0-10.0 \%$ plutonium content for RG-MOX and WG-MOX; rather than running additional SCALE/TRITON calculations, an interpolation procedure was undertaken. The $4.25 \%$ enrichment $\mathrm{k}_{\text {inf }}$ trajectory was approximated by interpolating between the $4.0 \%$ and $5.0 \% \mathrm{k}_{\text {inf }}$ trajectories. Using this procedure, the infinite multiplication factor at $20 \mathrm{GWd} / \mathrm{MTHM}$ for $4.25 \%{ }^{235} \mathrm{U}$ enrichment was calculated: $\mathrm{k}_{\text {inf }(20}$ $\mathrm{GWd} / \mathrm{MTHM})=1.08835$ for the PWR, and $\mathrm{k}_{\mathrm{inf}(20 \mathrm{GWd} / \mathrm{MTHM})}=1.15471$ for the BWR. Using the calculated infinite multiplication factors at $20 \mathrm{GWd} / \mathrm{MTHM}$, the equivalent RG-MOX and $\mathrm{WG}-\mathrm{PuO}_{2}$ in $\mathrm{MOX}$ is calculated for the both the PWR and the BWR by interpolating between the $\mathrm{k}_{\text {inf }}$ trajectories for RG-MOX and WG-MOX at $20 \mathrm{GWd} / \mathrm{MTHM}$ to give an equivalent eigenvalue to the UOX fuel. Using this procedure, the $\mathrm{RG}-\mathrm{PuO}_{2}$ or $\mathrm{WG}-\mathrm{PuO}_{2}$ content in $\mathrm{MOX}$ can be estimated.

For the PWR, the equivalent plutonium content is $7.914 \%$ for RG-Pu and $4.890 \%$ for WG-Pu. The interpolated eigenvalue trajectories for UOX, RG-MOX, and WG-MOX are shown in Fig. 3. For the BWR, the equivalent plutonium content is $8.701 \%$ for RG-Pu and $5.239 \%$ for WG-Pu. The interpolated eigenvalue trajectories for UOX, RG-MOX, and WG-MOX can be found in Fig. 4. The equivalent plutonium content values were used in the ORIGEN-ARP to calculate the post-irradiation decay heat. 


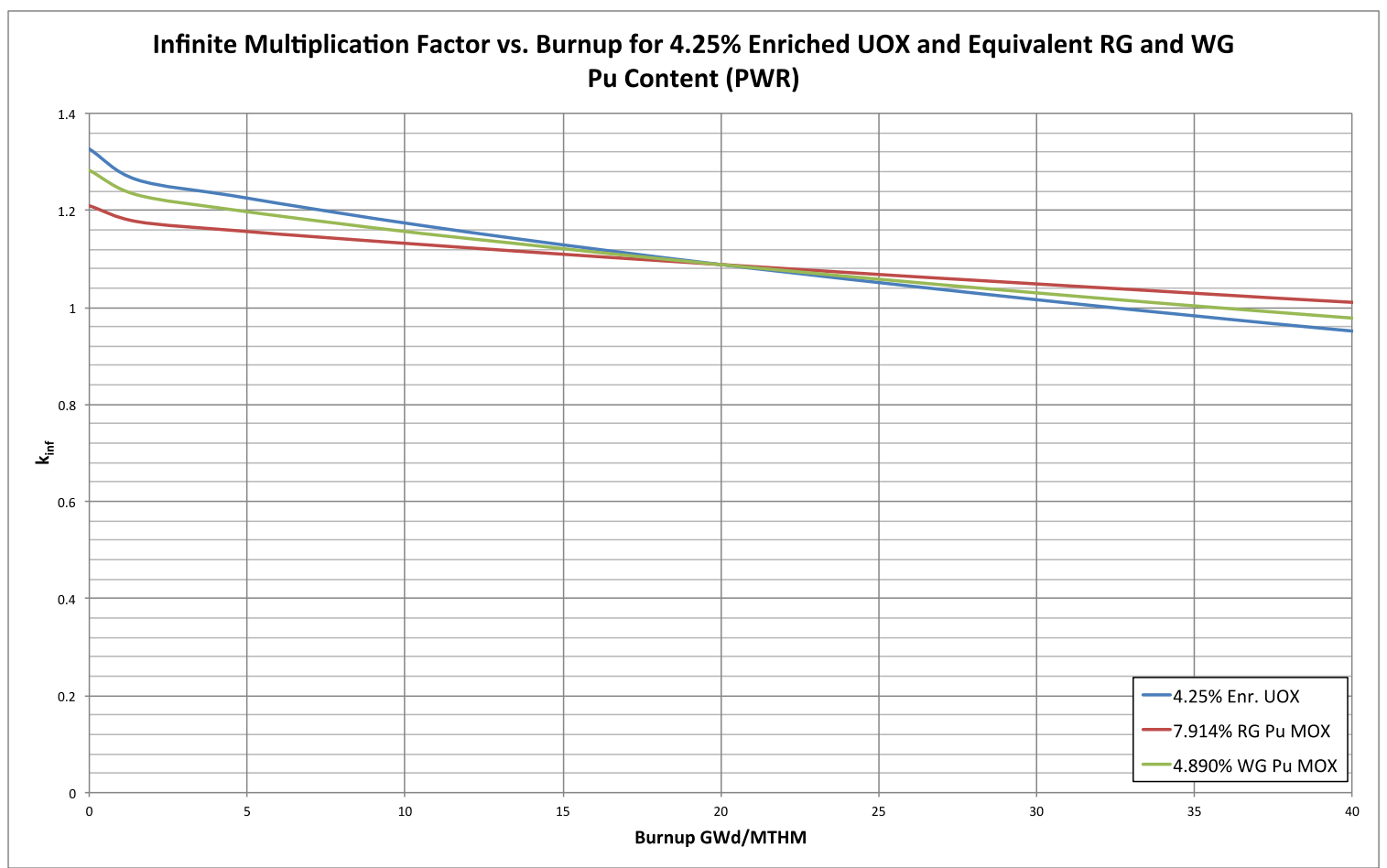

Fig. 3. Interpolated $\mathrm{k}_{\text {eff }}$ as a function of burnup for $4.25 \%$ enriched $\mathrm{UO}_{2}$ and equivalent $\mathrm{RG}-\mathrm{Pu}$ and WG-Pu for the PWR fuel bundle.

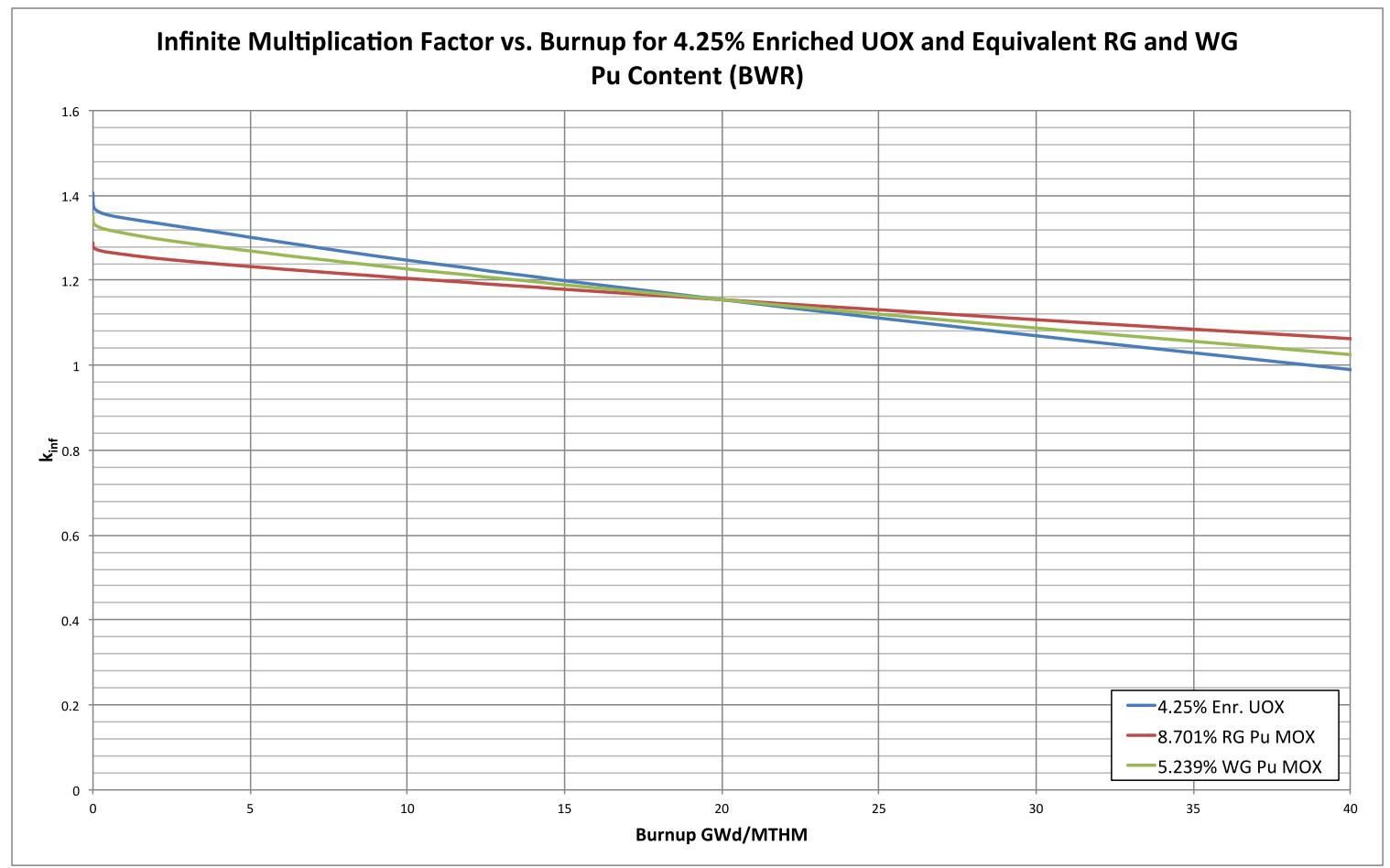

Fig. 4. Interpolated $\mathrm{k}_{\mathrm{eff}}$ as a function of burnup for $4.25 \%$ enriched $\mathrm{UO}_{2}$ and equivalent $\mathrm{RG}-\mathrm{Pu}$ and WG-Pu for the BWR fuel bundle. 


\subsection{PWR FUEL BUNDLE DECAY HEAT}

In this study, reported decay heat is normalized to a basis of 1 metric ton of initial heavy metal. A typical PWR fuel bundle contains approximately $460 \mathrm{~kg}$ of heavy metal, while a BWR fuel bundle typically contains approximately $200 \mathrm{~kg}$ of heavy metal. Decay heat curves for the PWR have been generated for four different discharge burnup points: $35,40,45$, and $50 \mathrm{GWd} / \mathrm{MTHM}$. As previously stated, the decay calculations range from 0 to over 19,000 days after discharge from the reactor. The decay heat data as a function of time for each discharge burnup are plotted in Figs. 5-8, A logarithmic scale is used on both the $\mathrm{x}$ - and $\mathrm{y}$-axes for convenient viewing of the data. As would be expected, the decay heat data for each discharge burnup shows a common trend. The difference in decay heat between UOX, RG-MOX, and WG-MOX through the first 10 days is relatively small but increases with time through 10,000 days. With UOX and MOX, the decay heat increases as a function of increasing discharge burnup. The increasing decay heat as a function of discharge burnup is expected due to the higher concentration of fission products and actinides in the fuel. The RG-MOX fuel consistently shows higher decay heat than the UOX or WG-MOX fuel due to the higher concentration of nuclides with reasonable probabilities of transmutation rather than fission (i.e., plutonium isotopes other than ${ }^{239} \mathrm{Pu}$ ), except for very early times after discharge. At times less than approximately 1 day after shutdown, the WG-MOX has decay heat values that are less than those of UOX for the same discharge burnup. The same is true for RG-MOX for approximately a 4 hour period after shutdown.

Another parameter of interest is the decay heat ratio of MOX to UOX. The decay heat ratio provides a simple way to compare the MOX decay heat relative to the decay heat of UOX fuel. The decay heat ratio as a function of time for the first 10 days after discharge is shown in Figs. 9-10 for RG-MOX and WGMOX, respectively. Likewise, in Fig. 11, the decay heat ratio as a function of time has been plotted from 0 to 15,000 days for RG-MOX and WG-MOX, respectively. In Fig. 12 the decay heat ratios are plotted using the same scale on the y-axes to facilitate comparison of the decay heat ratio between RG-MOX and WG-MOX. The decay heat ratio for RG-MOX is significantly higher than that for WG-MOX almost immediately after discharge. The decay heat ratios for the PWR are summarized in Table 4.

Another parameter of interest is the "crossover point," that is, the time after discharge at which the MOX fuel generates more decay heat than UOX. The crossover points for RG-MOX and WG-MOX in the PWR fuel bundle can be found in Table 5. The crossover point for the PWR fuel bundle is generally insensitive for different discharge burnup - the crossover point for RG-MOX and WG-MOX is less than 1 day. 


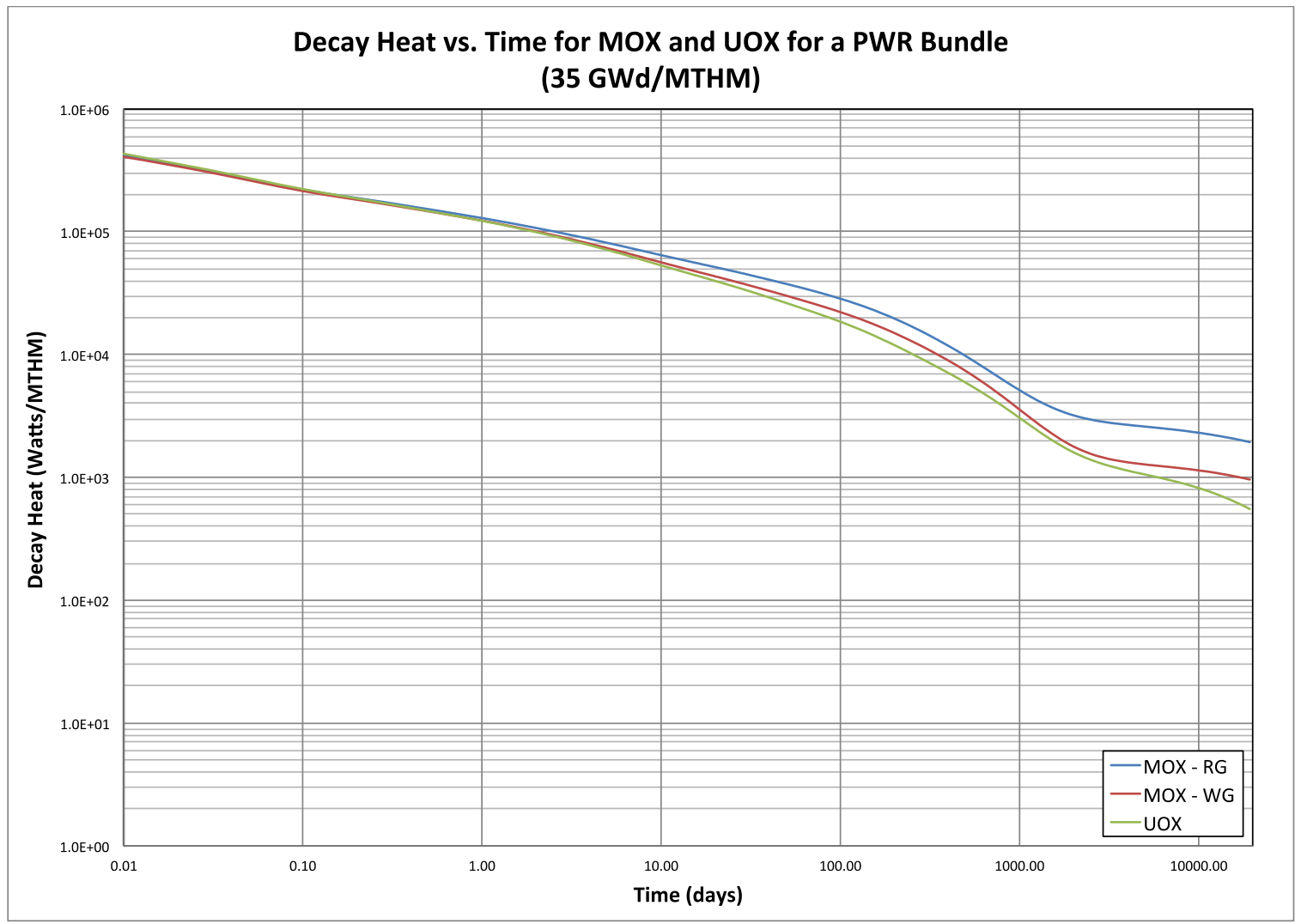

Fig. 5. PWR fuel bundle decay heat as a function of time after discharge at $35 \mathrm{GWd} / \mathrm{MTHM}$.

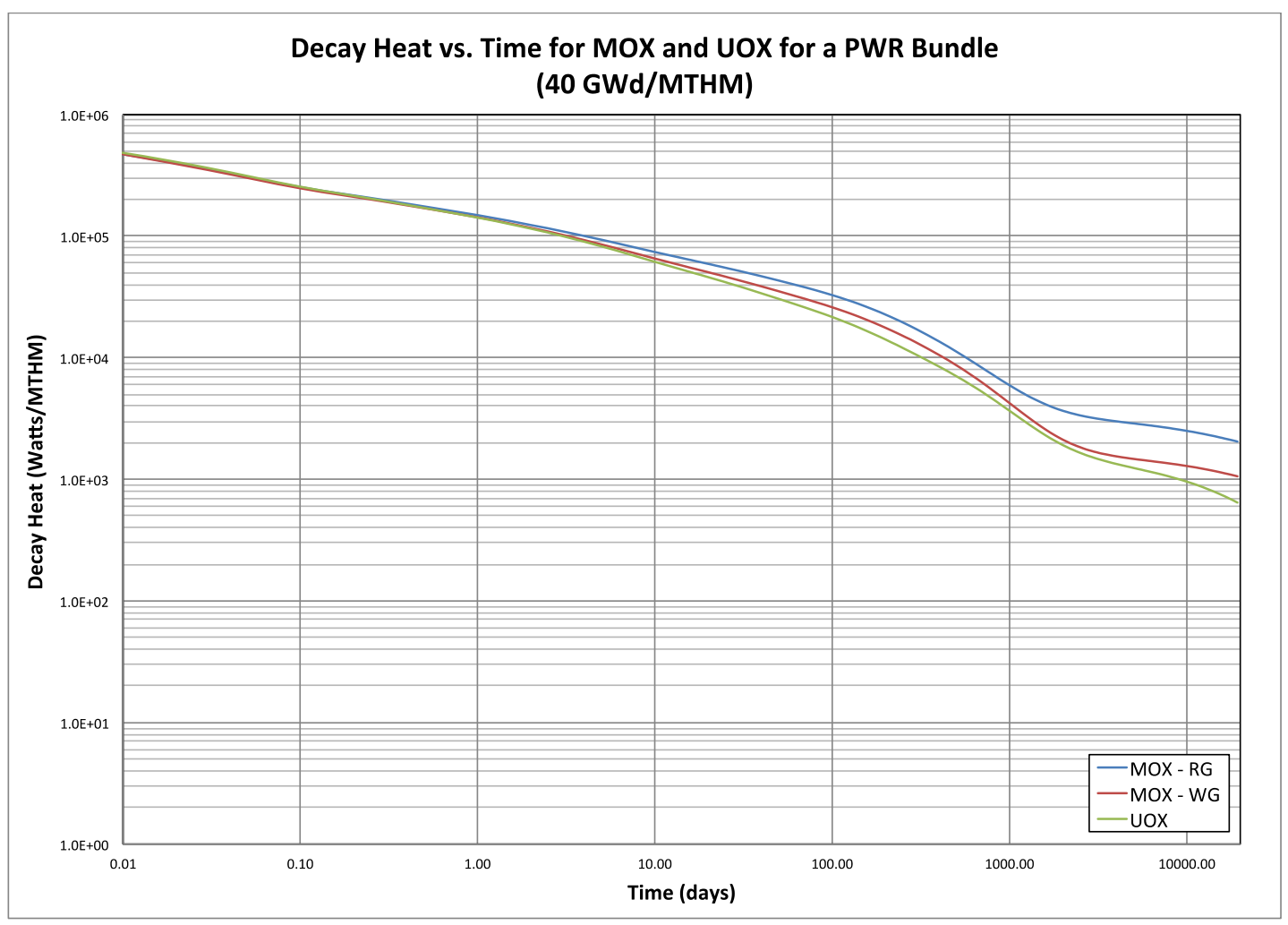

Fig. 6. PWR fuel bundle decay heat as a function of time after discharge at $40 \mathrm{GWd} / \mathrm{MTHM}$. 


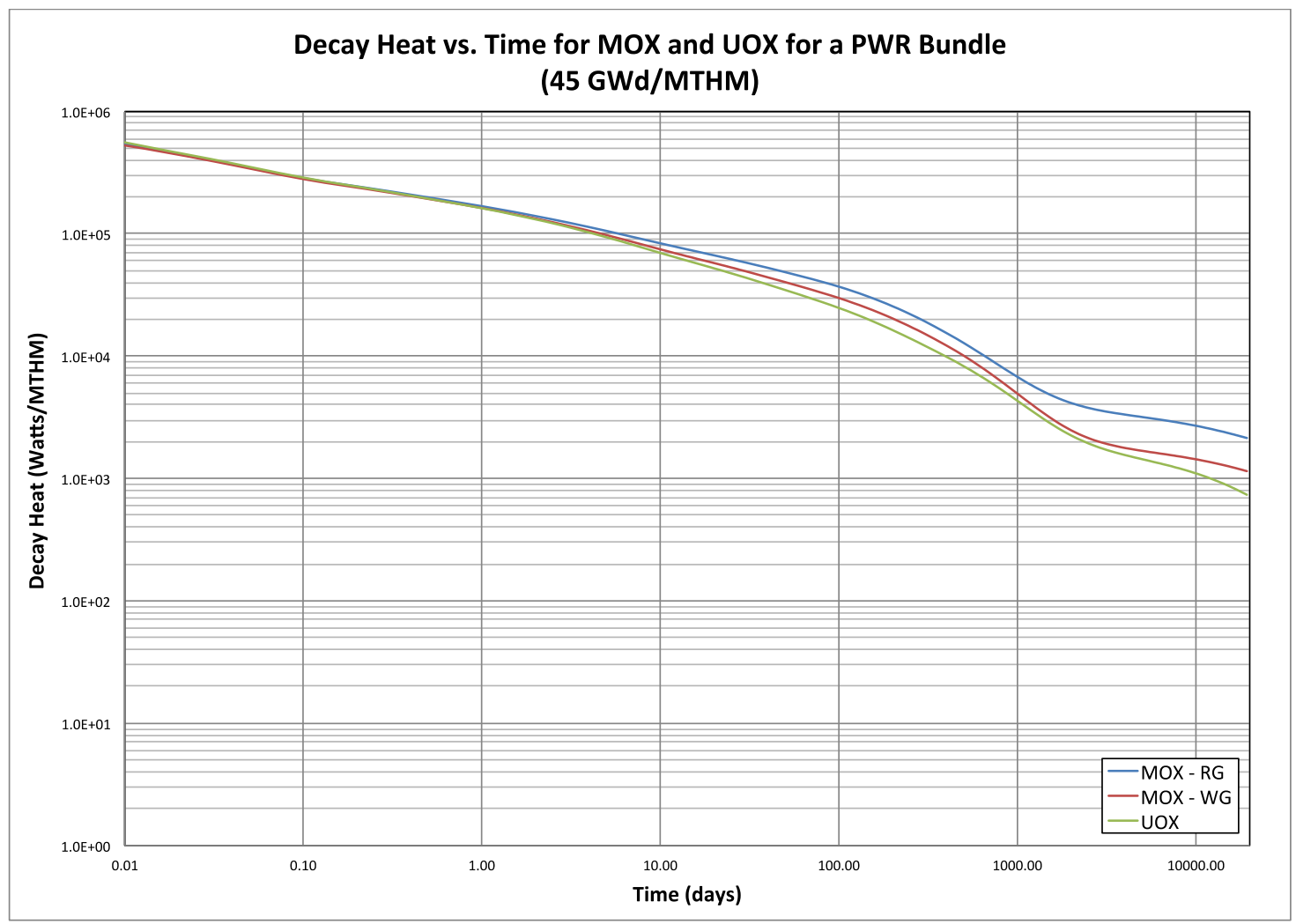

Fig. 7. PWR fuel bundle decay heat as a function of time after discharge at $45 \mathrm{GWd} / \mathrm{MTHM}$.

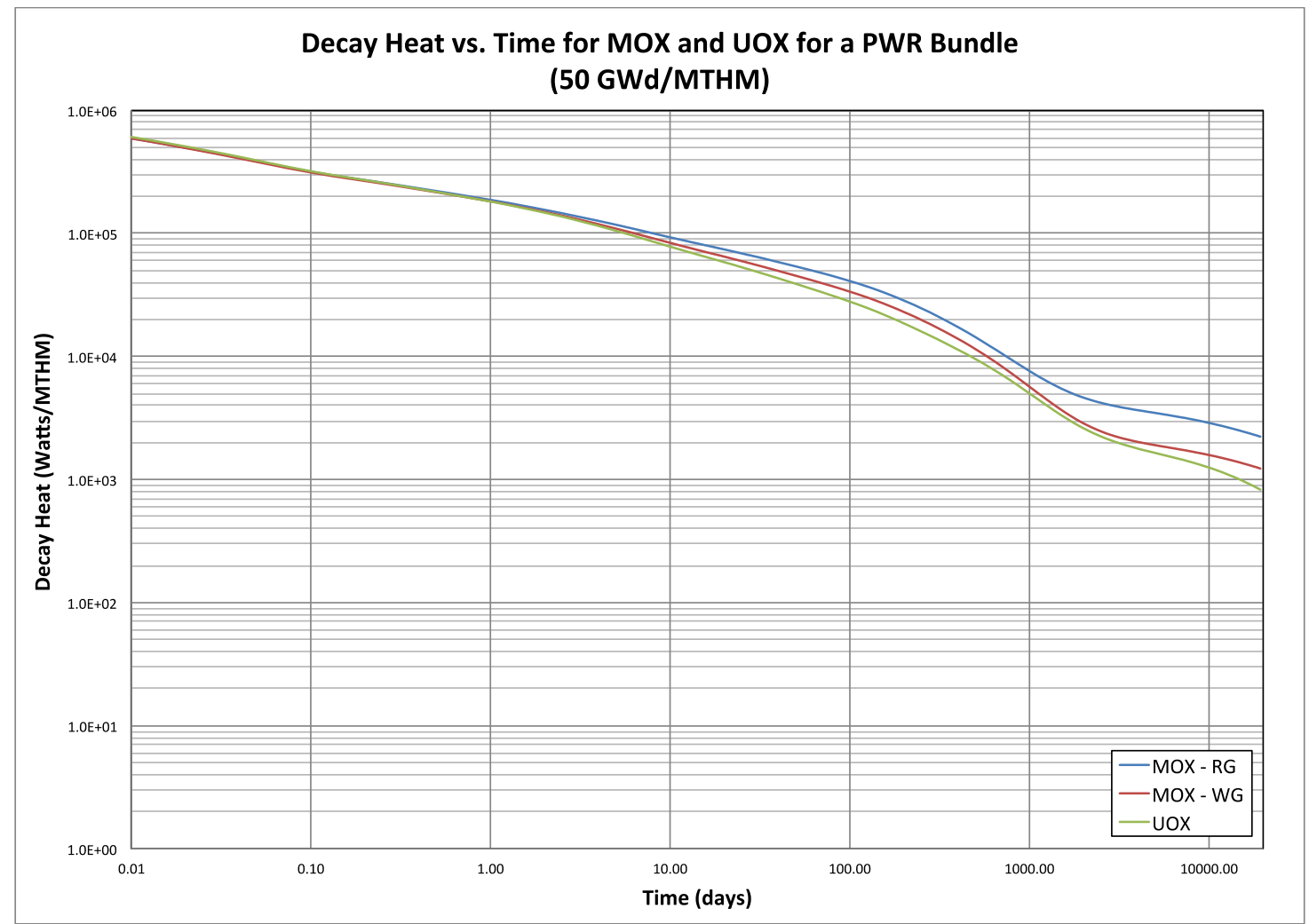

Fig. 8. PWR fuel bundle decay heat as a function of time after discharge at $50 \mathrm{GWd} / \mathrm{MTHM}$. 


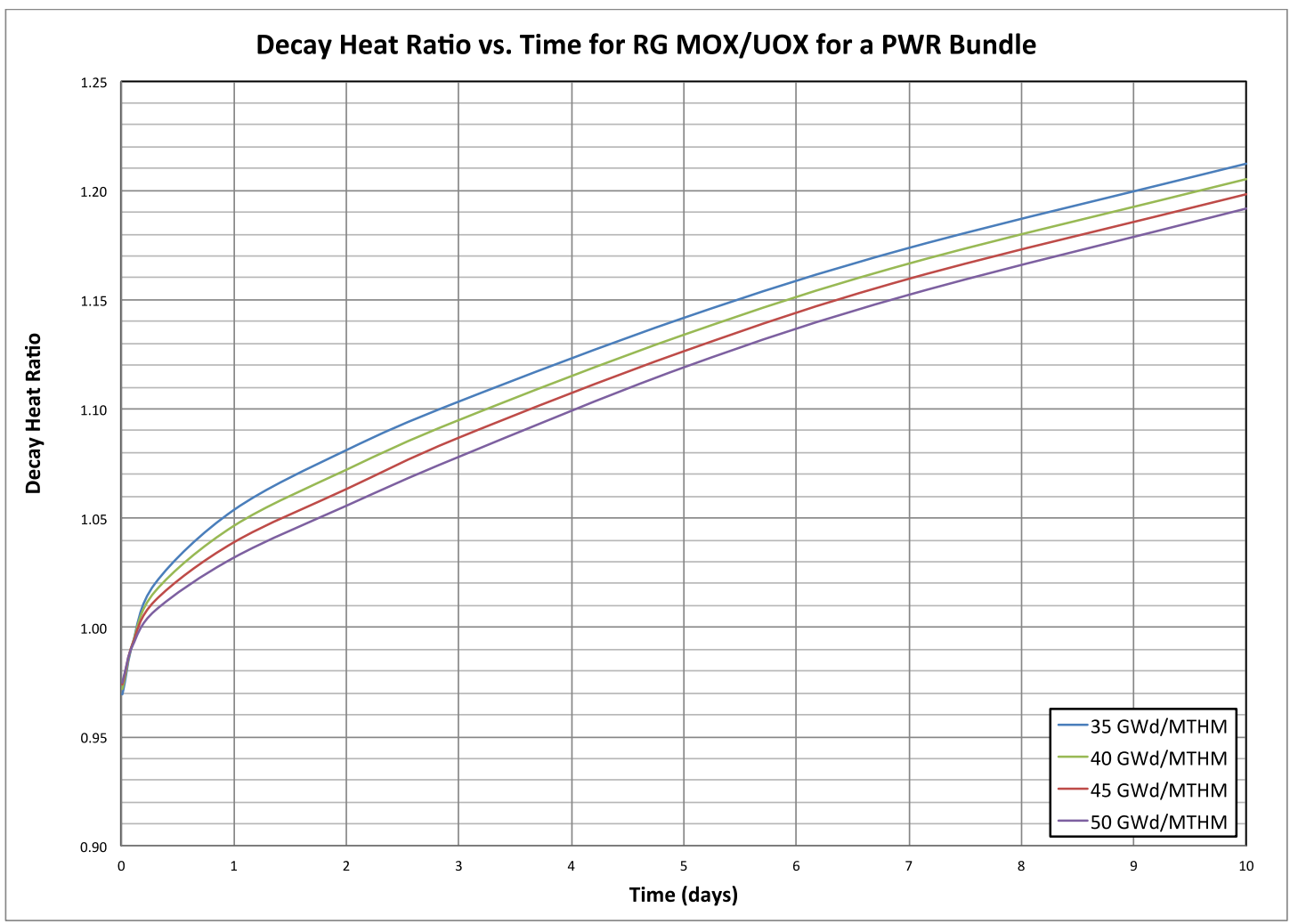

Fig. 9. Decay heat ratio as a function of time for RG-MOX for the first 10 days after discharge (PWR).

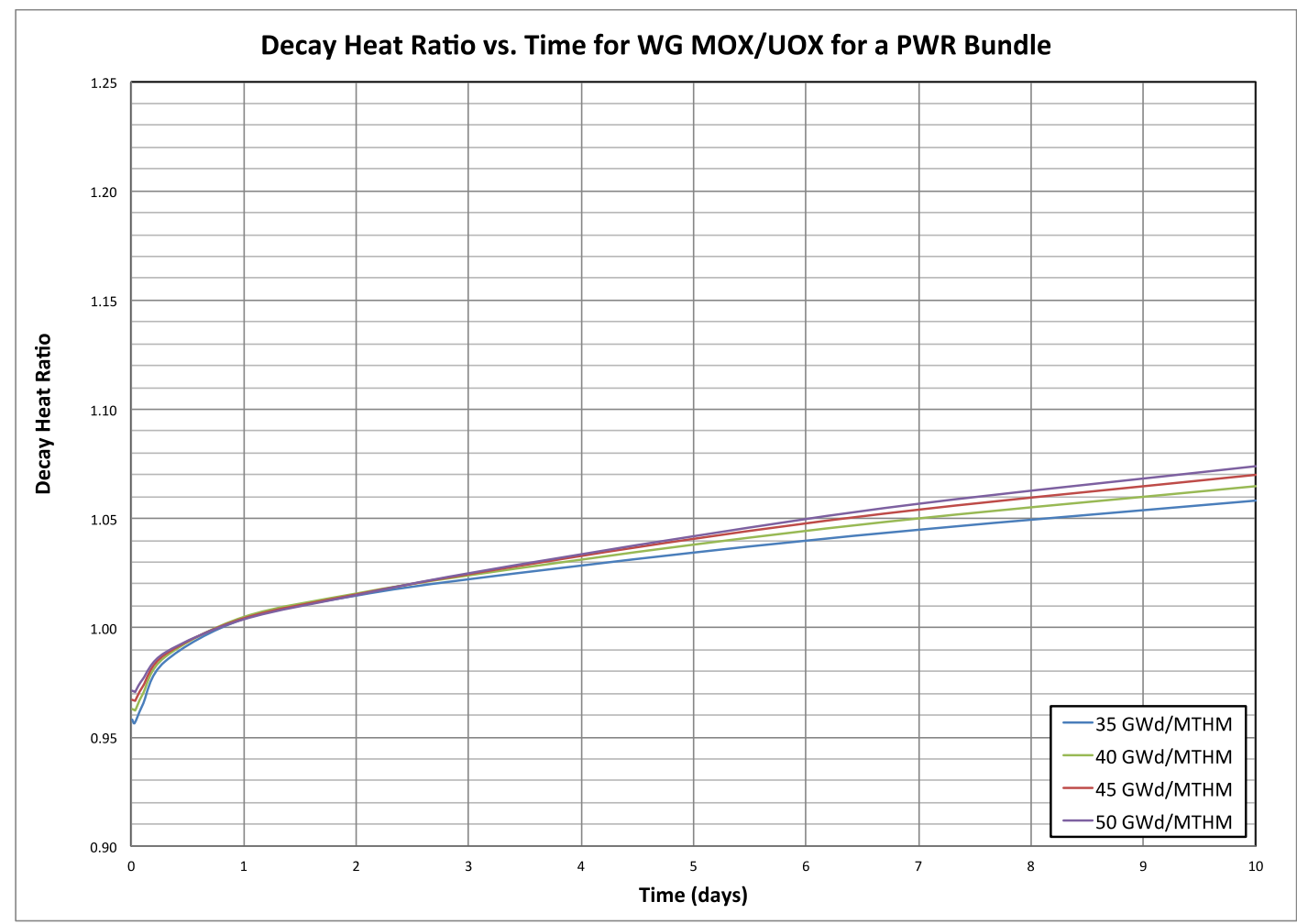

Fig. 10. Decay heat ratio as a function of time for WG-MOX for the first 10 days after discharge (PWR). 


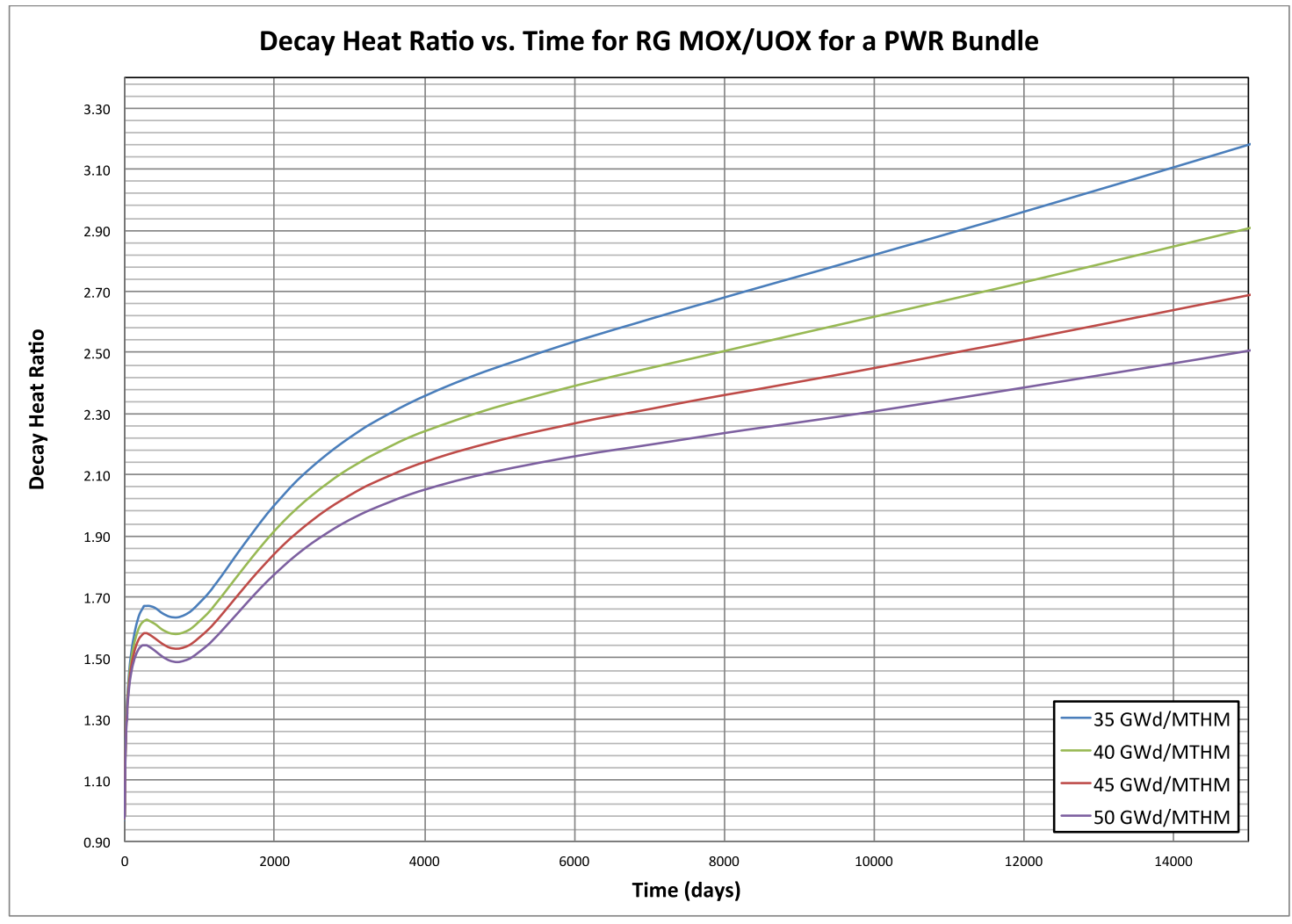

Fig. 11. Decay heat ratio as a function of time for RG-MOX for the first 15,000 days after discharge (PWR).

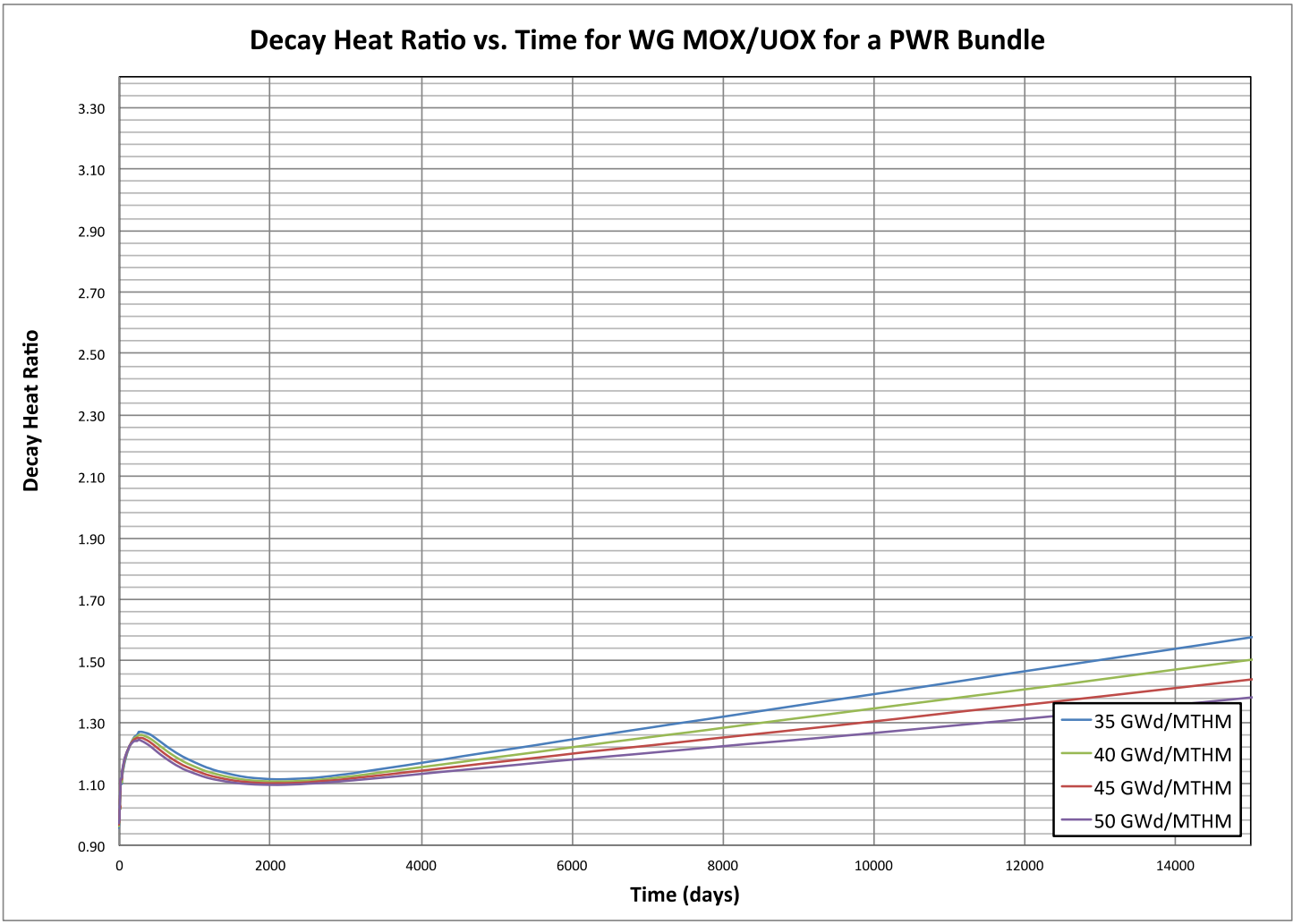

Fig. 12. Decay heat ratio as a function of time for WG-MOX for the first $\mathbf{1 5 , 0 0 0}$ days after discharge (PWR) 
Table 4. Decay heat ratios for the PWR fuel bundle at selected cooling time

\begin{tabular}{rcccccccc}
\hline \multirow{2}{*}{$\begin{array}{r}\text { Time } \\
\text { days) }\end{array}$} & \multicolumn{2}{c}{$\mathbf{3 5} \mathbf{G W d}$ /MTU } & \multicolumn{2}{c}{$\mathbf{4 0} \mathbf{G W d}$ /MTU } & \multicolumn{2}{c}{ 45 GWd/MTU } & \multicolumn{2}{c}{$\mathbf{5 0}$ GWd/MTU } \\
\cline { 2 - 9 } & RG-MOX & WG-MOX & RG-MOX & WG-MOX & RG-MOX & WG-MOX & RG-MOX & WG-MOX \\
\hline $\mathbf{0 . 1}$ & 0.99 & 0.96 & 0.99 & 0.97 & 0.99 & 0.97 & 0.99 & 0.98 \\
$\mathbf{0 . 5}$ & 1.03 & 0.99 & 1.03 & 0.99 & 1.02 & 0.99 & 1.01 & 0.99 \\
$\mathbf{1}$ & 1.05 & 1.00 & 1.05 & 1.00 & 1.04 & 1.00 & 1.03 & 1.00 \\
$\mathbf{5}$ & 1.14 & 1.03 & 1.13 & 1.04 & 1.13 & 1.04 & 1.12 & 1.04 \\
$\mathbf{1 0}$ & 1.21 & 1.06 & 1.21 & 1.06 & 1.20 & 1.07 & 1.19 & 1.07 \\
$\mathbf{1 0 0}$ & 1.54 & 1.20 & 1.52 & 1.20 & 1.49 & 1.20 & 1.47 & 1.20 \\
$\mathbf{5 0 0}$ & 1.65 & 1.25 & 1.59 & 1.23 & 1.55 & 1.22 & 1.50 & 1.20 \\
$\mathbf{1 0 0 0}$ & 1.68 & 1.17 & 1.62 & 1.16 & 1.57 & 1.14 & 1.52 & 1.13 \\
$\mathbf{5 0 0 0}$ & 2.45 & 1.21 & 2.32 & 1.19 & 2.21 & 1.17 & 2.11 & 1.16 \\
$\mathbf{1 0 0 0 0}$ & 2.82 & 1.39 & 2.62 & 1.35 & 2.45 & 1.30 & 2.31 & 1.27 \\
\hline $\mathbf{1 5 0 0 0}$ & 3.18 & 1.58 & 2.91 & 1.50 & 2.69 & 1.44 & 2.51 & 1.38 \\
\hline
\end{tabular}

Table 5. RG-MOX and WG-MOX crossover points for different discharge burnup for the PWR

\begin{tabular}{ccc}
\hline \multirow{2}{*}{$\begin{array}{c}\text { Burnup } \\
\text { (GWd/MTHM) }\end{array}$} & \multicolumn{2}{c}{$\begin{array}{c}\text { Crossover point } \\
\text { (days) }\end{array}$} \\
\cline { 2 - 3 } & RG-MOX & WG-MOX \\
\hline $\mathbf{3 5}$ & 0.155 & 0.854 \\
$\mathbf{4 0}$ & 0.162 & 0.812 \\
$\mathbf{4 5}$ & 0.177 & 0.817 \\
$\mathbf{5 0}$ & 0.204 & 0.823 \\
\hline
\end{tabular}

\subsection{BWR FUEL BUNDLE DECAY HEAT}

Like the PWR fuel bundle, the decay heat curves for the BWR were generated for four different discharge burnup points: 35, 40, 45, and $50 \mathrm{GWd} / \mathrm{MTHM}$. As before, the decay calculations range from 0 to over 19,000 days after discharge from the reactor. The decay heat data as a function of time for each discharge burnup have been plotted in Figs. 13-16. As would be expected, the decay heat data for each discharge burnup shows a common trend. The difference in decay heat between UOX, RG-MOX, and WG-MOX through the first ten days is relatively small, and increases with time through 10,000 days. With UOX and MOX, the decay heat increases as a function of increasing discharge burnup. The increasing decay heat as a function of discharge burnup is expected due to the higher concentration of fission products and actinides in the fuel. The reactor-grade MOX fuel consistently shows higher decay heat than the UOX or weapons-grade MOX fuel due to the higher concentration of nuclides with reasonable probabilities of transmutation rather than fission (plutonium isotopes other than ${ }^{239} \mathrm{Pu}$ ).

The decay heat ratio as a function of time for the first 10 days after discharge can be found in Figs. 17-18 for RG-MOX and WG-MOX, respectively. Likewise, in Fig. 19, the decay heat ratio as a function of time has been plotted from 0 to 15000 days for RG-MOX and WG-MOX, respectively. In Figs. 17-20, the decay heat ratios are plotted using the same scale on the y-axes to facilitate comparison of the decay heat 
ratio between RG-MOX and WG-MOX. The decay heat ratio for RG-MOX is significantly higher than for WG-MOX almost immediately after discharge. The decay heat ratios for the BWR have been summarized in Table 6.

The crossover points for RG-MOX and WG-MOX in the BWR fuel bundle can be found in Table 7. The crossover point for the BWR fuel bundle is more sensitive to discharge burnup than the PWR, especially for RG-MOX. All the BWR RG-MOX crossover points are less than 1 day but have a larger span of $\sim 0.4$ days from low burnup to high burnup. The BWR WG-MOX crossover point is greater than for the PWR. The BWR crossover point is $\sim 2$ days for all discharge burnup points.

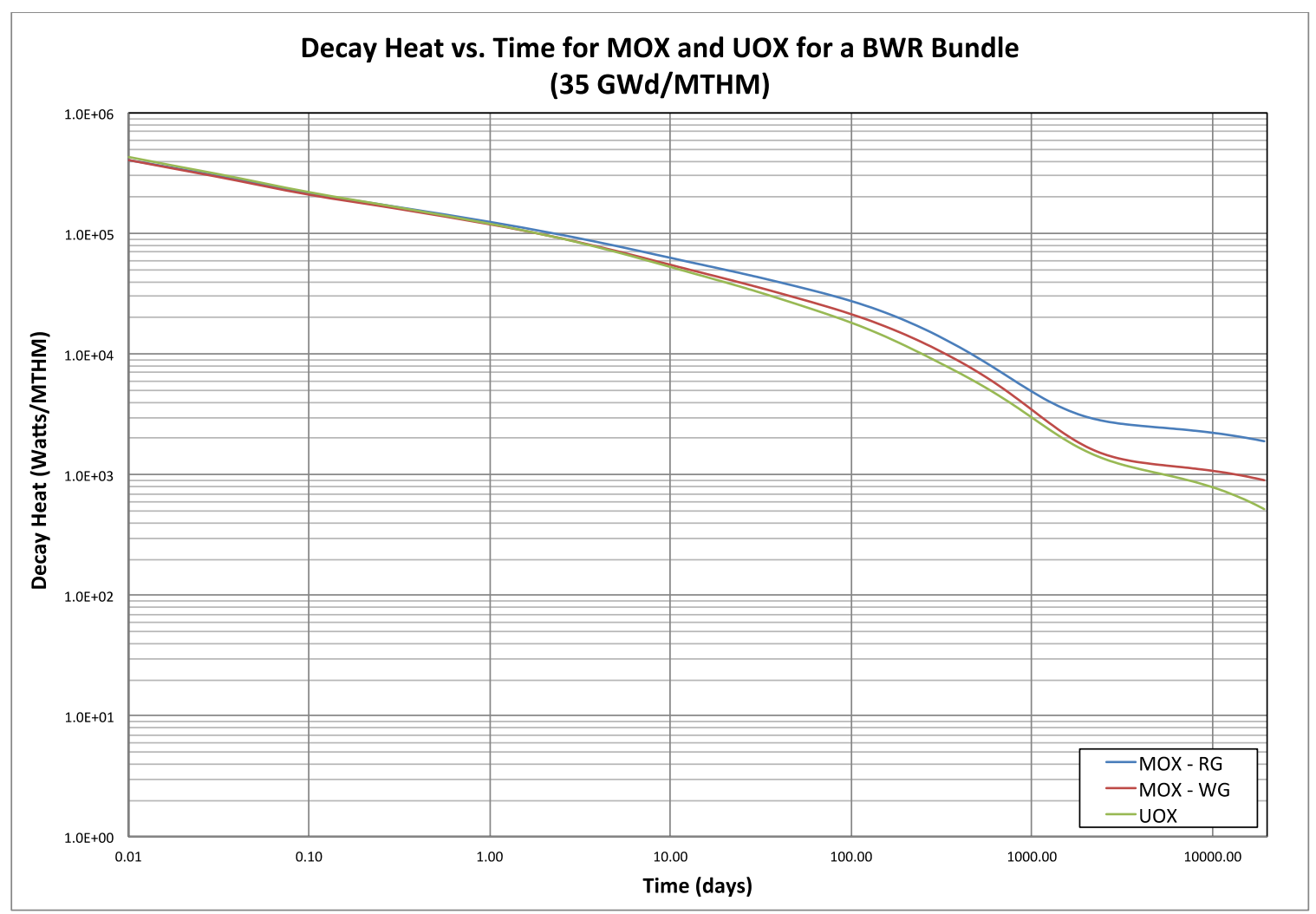

Fig. 13. BWR fuel bundle decay heat as a function of time after discharge at $35 \mathrm{GWd} / \mathrm{MTHM}$. 


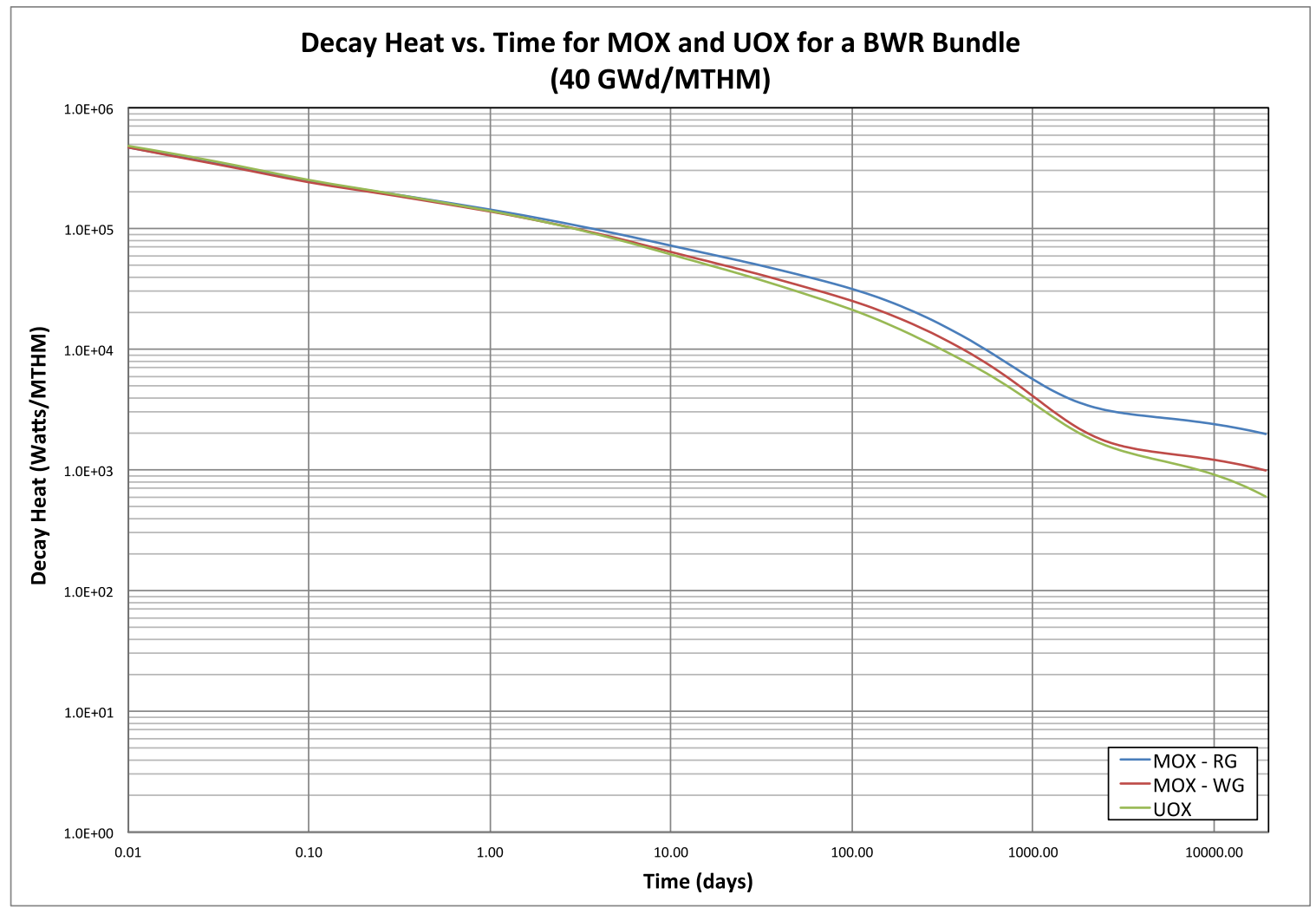

Fig. 14. BWR fuel bundle decay heat as a function of time after discharge at $40 \mathrm{GWd} / \mathrm{MTHM}$.

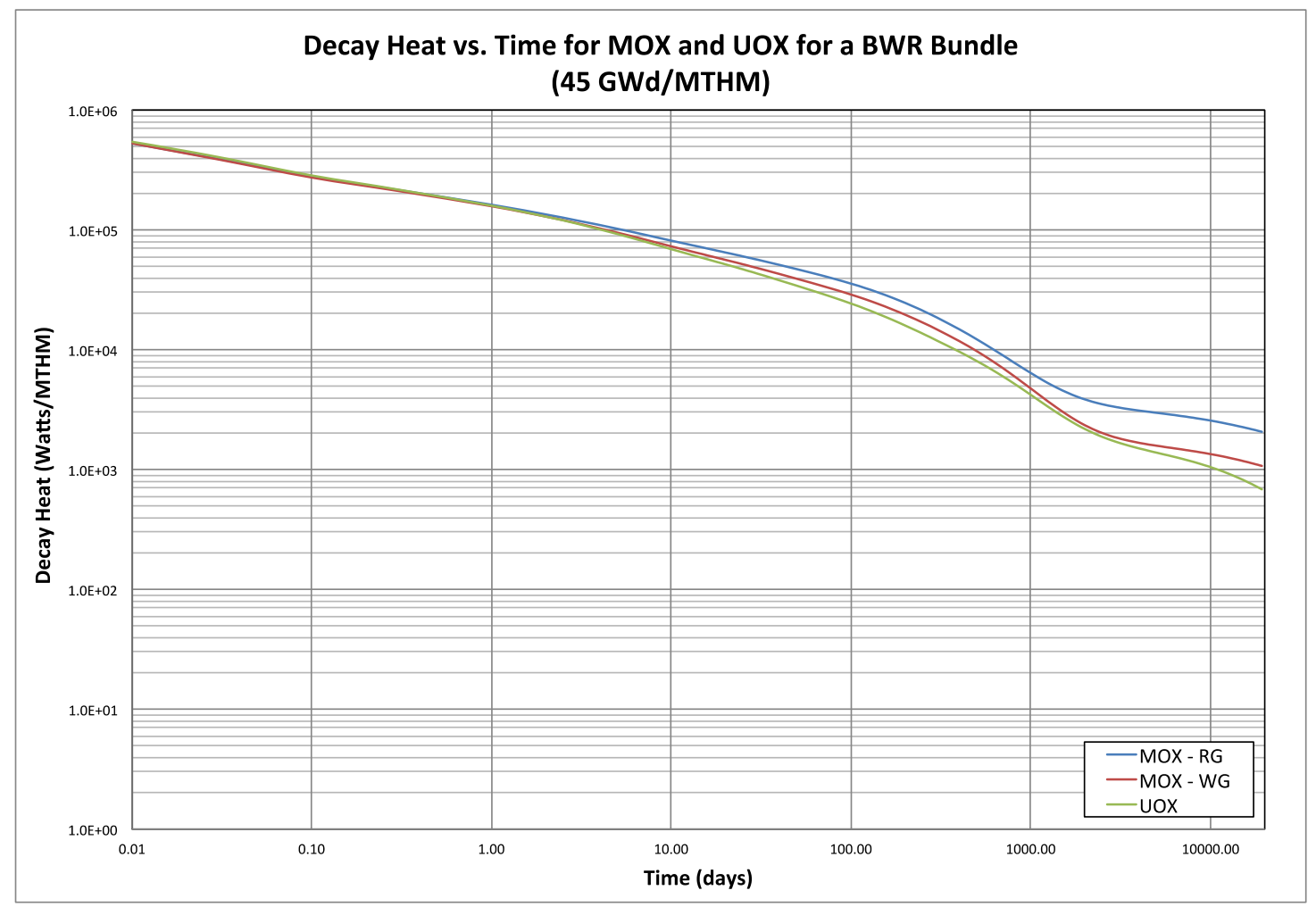

Fig. 15. BWR fuel bundle decay heat as a function of time after discharge at $45 \mathrm{GWd} / \mathrm{MTHM}$. 


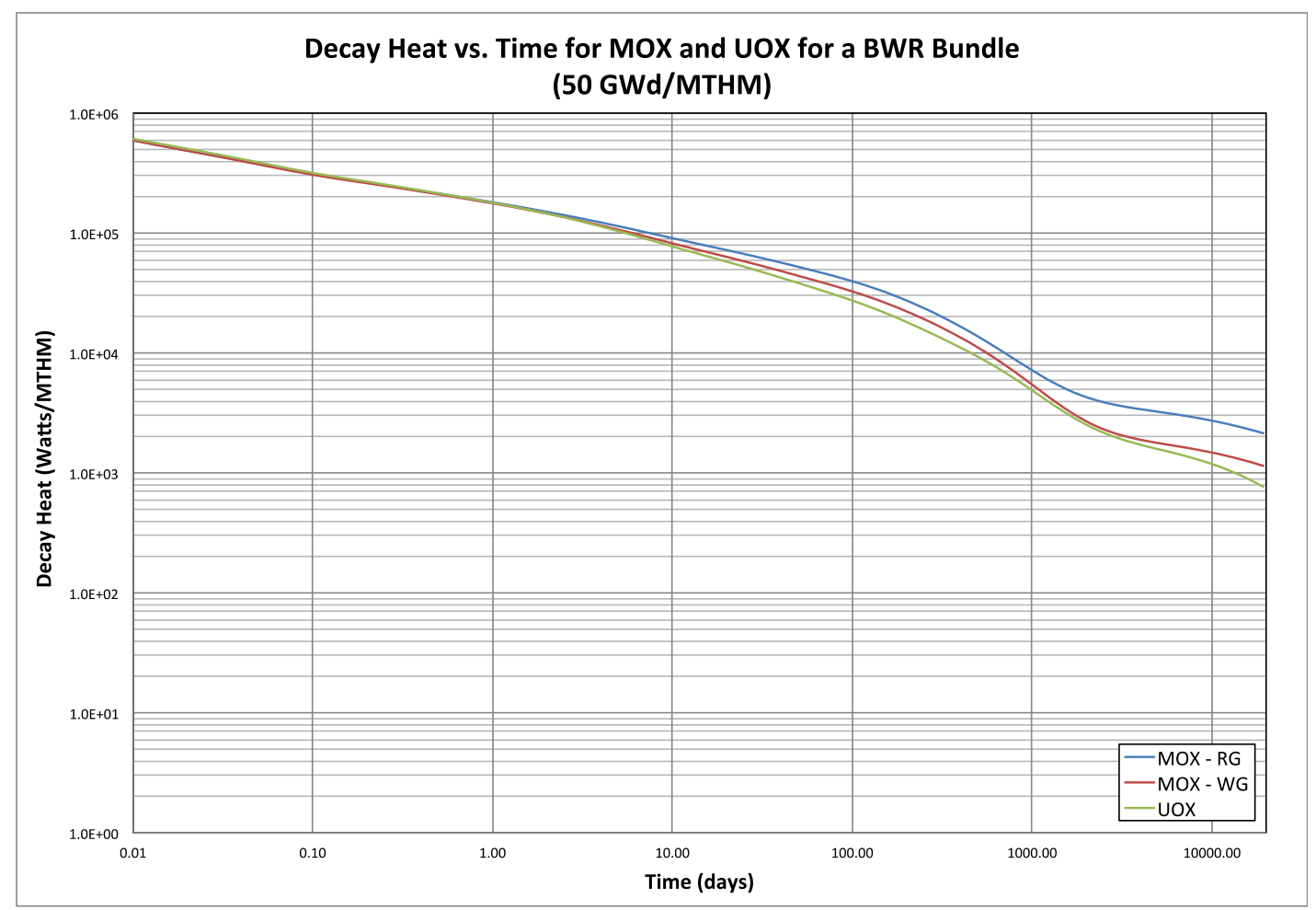

Fig. 16. BWR fuel bundle decay heat as a function of time after discharge at $50 \mathrm{GWd} / \mathrm{MTHM}$.

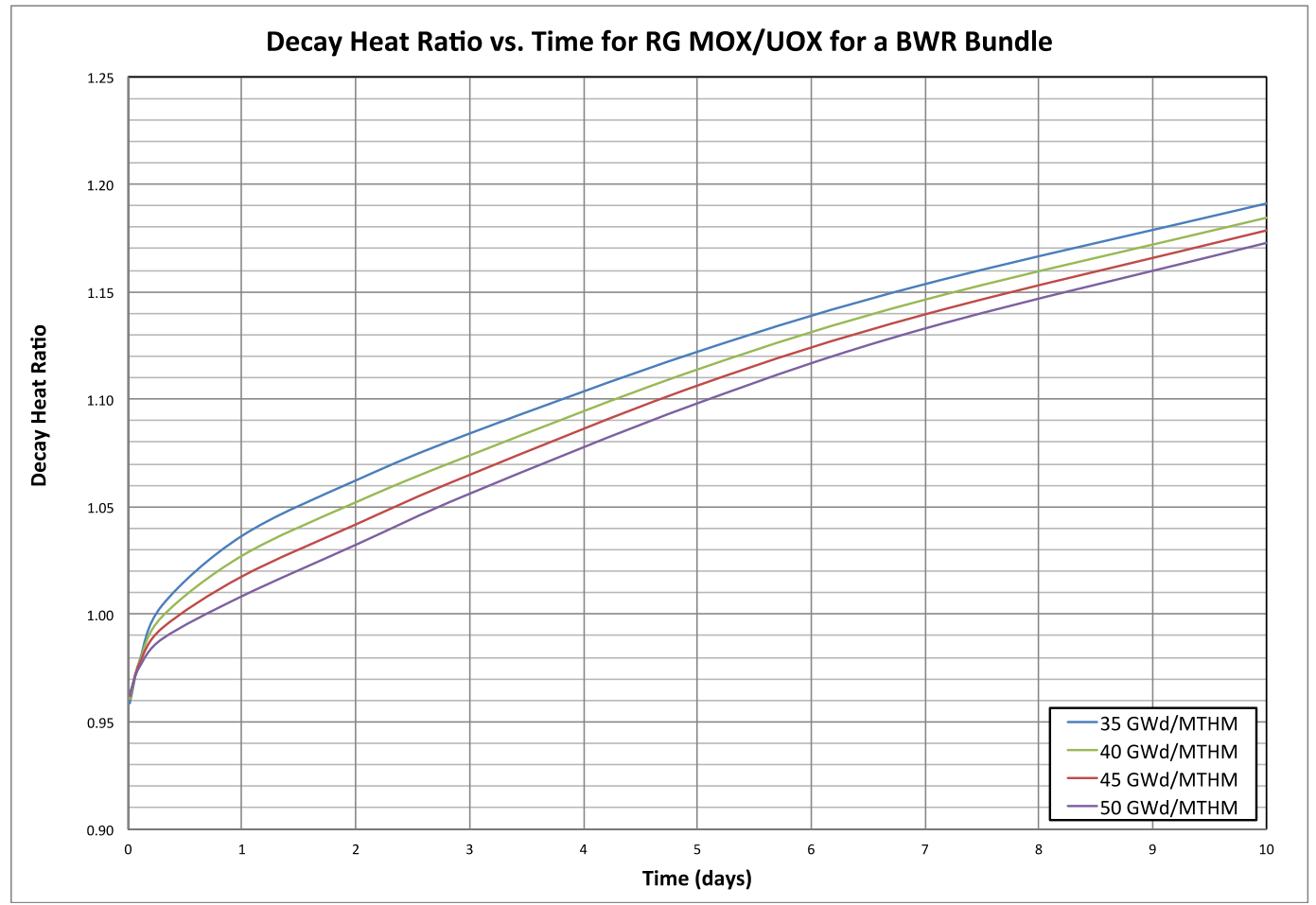

Fig. 17. Decay heat ratio as a function of time for RG-MOX for the first 10 days after discharge (BWR). 


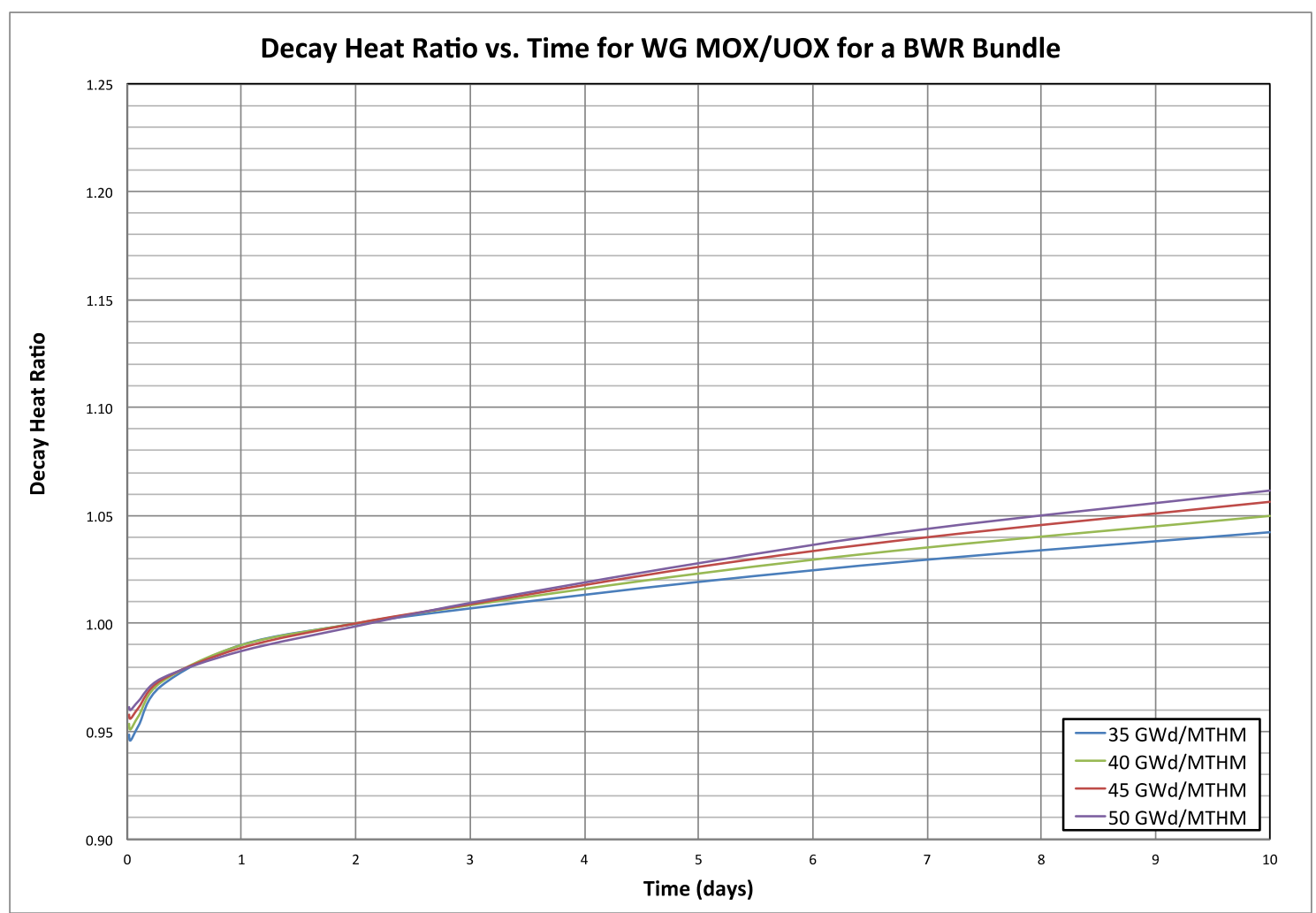

Fig. 18. Decay heat ratio as a function of time for WG-MOX for the first 10 days after discharge (BWR).

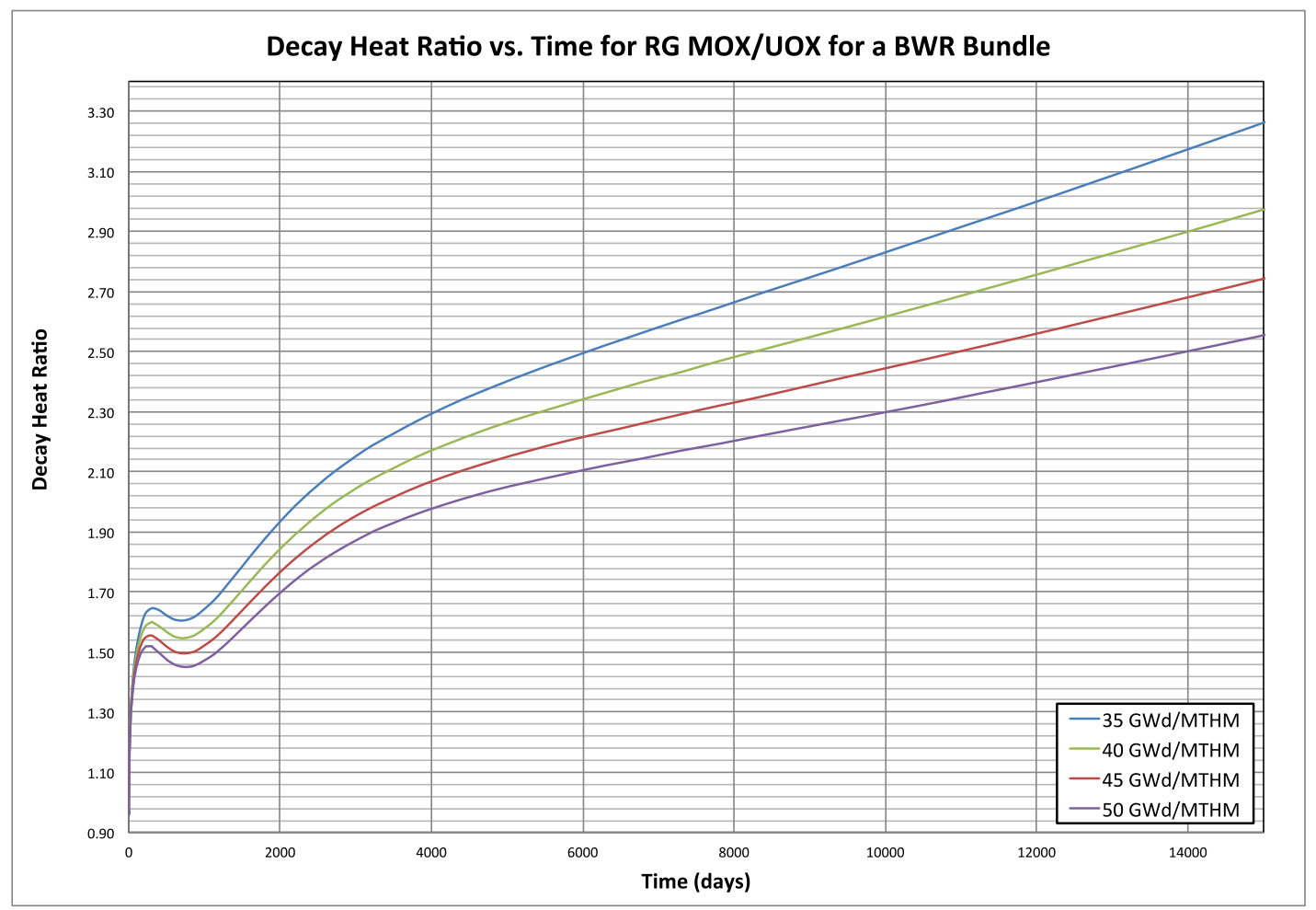

Fig. 19. Decay heat ratio as a function of time for RG-MOX for the first 15,000 days after discharge (BWR). 


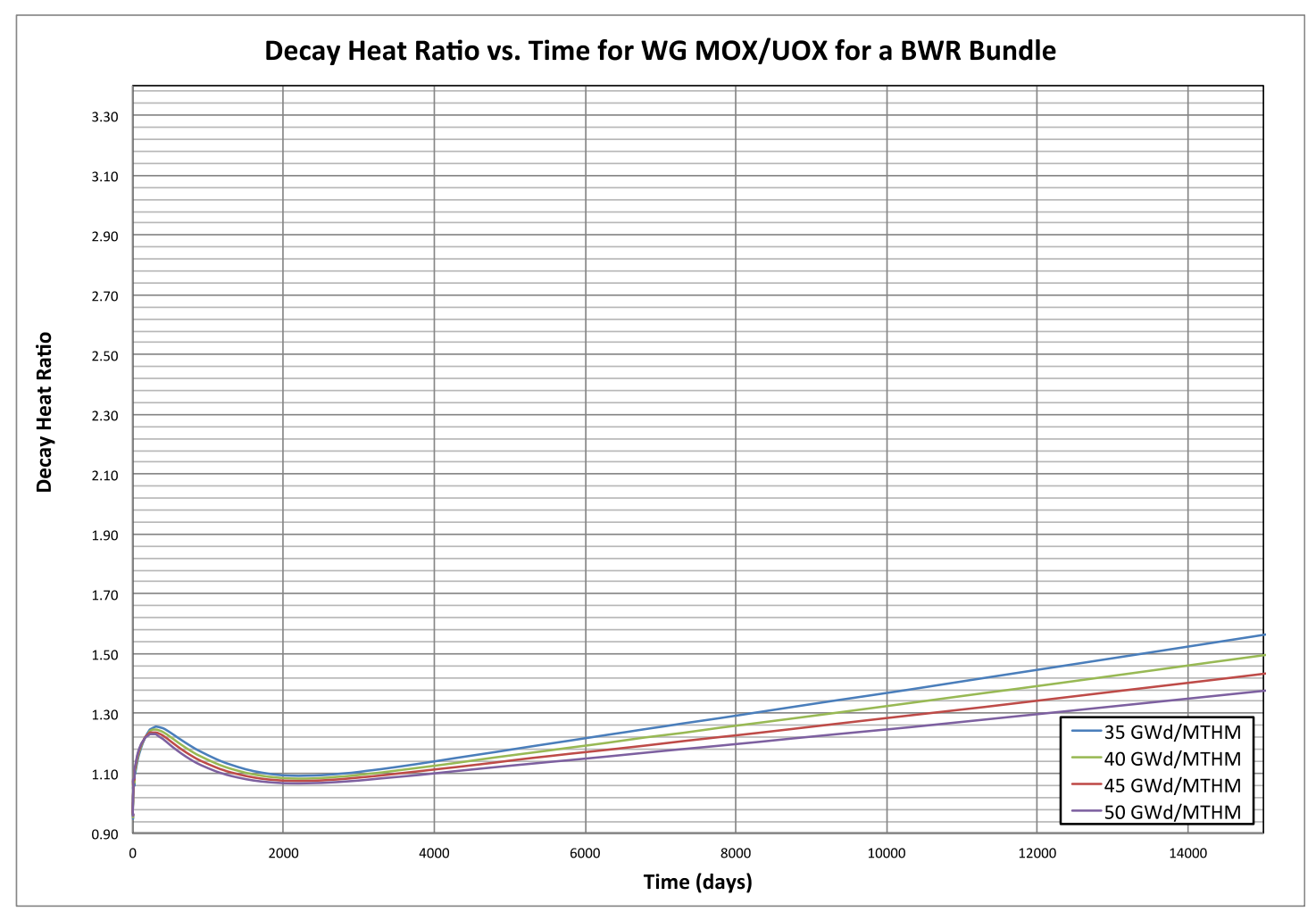

Fig. 20. Decay heat ratio as a function of time for WG-MOX for the first 15,000 days after discharge (BWR).

Table 6. Decay heat ratios for the BWR fuel bundle at selected points

\begin{tabular}{ccccccccc}
\hline Time & \multicolumn{2}{c}{ 35 GWd/MTU } & \multicolumn{2}{c}{ 40 GWd/MTU } & \multicolumn{2}{c}{ 45 GWd/MTU } & \multicolumn{2}{c}{ 50 GWd/MTU } \\
\cline { 2 - 8 } (days & RG-MOX & WG-MOX & RG-MOX & WG-MOX & RG-MOX & WG-MOX & RG-MOX & WG-MOX \\
\hline $\mathbf{0 . 1}$ & 0.98 & 0.95 & 0.98 & 0.96 & 0.98 & 0.96 & 0.98 & 0.96 \\
$\mathbf{0 . 5}$ & 1.01 & 0.98 & 1.01 & 0.98 & 1.00 & 0.98 & 0.99 & 0.98 \\
$\mathbf{1}$ & 1.04 & 0.99 & 1.03 & 0.99 & 1.02 & 0.99 & 1.01 & 0.99 \\
$\mathbf{5}$ & 1.12 & 1.02 & 1.11 & 1.02 & 1.11 & 1.03 & 1.10 & 1.03 \\
$\mathbf{1 0}$ & 1.19 & 1.04 & 1.18 & 1.05 & 1.18 & 1.06 & 1.17 & 1.06 \\
$\mathbf{1 0 0}$ & 1.51 & 1.18 & 1.49 & 1.18 & 1.47 & 1.19 & 1.45 & 1.19 \\
$\mathbf{5 0 0}$ & 1.62 & 1.24 & 1.57 & 1.22 & 1.52 & 1.21 & 1.48 & 1.19 \\
$\mathbf{1 0 0 0}$ & 1.64 & 1.16 & 1.58 & 1.14 & 1.52 & 1.13 & 1.47 & 1.12 \\
$\mathbf{5 0 0 0}$ & 2.40 & 1.18 & 2.26 & 1.16 & 2.15 & 1.14 & 2.05 & 1.13 \\
$\mathbf{1 0 0 0 0}$ & 2.83 & 1.37 & 2.62 & 1.32 & 2.44 & 1.28 & 2.30 & 1.25 \\
$\mathbf{1 5 0 0 0}$ & 3.26 & 1.56 & 2.97 & 1.49 & 2.74 & 1.43 & 2.56 & 1.38 \\
\hline
\end{tabular}


Table 7. RG-MOX and WG-MOX crossover points for different discharge burnup for the BWR

\begin{tabular}{ccc}
\hline Burnup & \multicolumn{2}{c}{ Crossover point (days) } \\
\cline { 2 - 3 } (GWd/MTHM) & RG-MOX & WG-MOX \\
\hline $\mathbf{3 5}$ & 0.268 & 2.029 \\
$\mathbf{4 0}$ & 0.326 & 2.000 \\
$\mathbf{4 5}$ & 0.488 & 2.000 \\
$\mathbf{5 0}$ & 0.705 & 2.127 \\
\hline
\end{tabular}




\section{SUMMARY}

In this research, decay heat rates for UOX, RG-MOX, and WG-MOX fuel were calculated for a typical PWR and a typical BWR fuel assembly using the SCALE code system. The decay heat rates for RGMOX and WG-MOX were compared to UOX. Instead of using SCALE/ORIGEN-ARP libraries available in the SCALE distribution, ORIGEN-ARP libraries were generated for both the PWR and BWR using a specific and identical fuel composition. In order to obtain the approximate equivalent $\mathrm{PuO}_{2}$ content in MOX compared to a given ${ }^{235} \mathrm{U}$ enrichment in UOX, an interpolation procedure was performed. The approximate equivalent $\mathrm{PuO}_{2}$ content was used in SCALE/ORIGEN-ARP calculations to calculate decay heat rates up to nearly 20,000 days after discharge from the reactor.

The PWR and BWR calculated decay heat rates were similar. In general, for periods beyond the first day, using MOX fuel results in a higher specific decay heat rate than UOX. Reactor-grade plutonium in MOX fuel results in higher decay heat than using WG plutonium in MOX fuel. The crossover points for the PWR fuel assembly at all discharge burnup points analyzed are less than 0.25 days for RG-MOX and less than 0.9 days for WG-MOX. For the BWR fuel assembly, the crossover points at all discharge burnup points analyzed are less than 0.75 days for RG-MOX and $~ 2.0$ days for WG-MOX. The decay heat ratios at decay times greater than 10 days are very similar for the PWR and BWR fuel bundles. In general, the decay heat ratio (MOX/UOX) increases with increasing time after discharge and decreases with increasing discharge burnup.

At discharge, used UOX and used MOX fuel show similar decay heat characteristics because of shortlived fission products, and continuing fission due to delayed neutrons. As time after discharge increases, differences in the relative amount of fission products and actinides in UOX and MOX, which are affected by the initial fuel composition and operating history, are the main contributors to the decay heat. 


\section{REFERENCES}

DeHart, M. D., \& Bowman, S. M. (2011). Reactor Physics Methods and Analysis Capabilities in SCALE. Nuclear Technology, 174 (2), 196-213.

Framatome ANP, Inc. (2003). MOX Fuel Design Report. U.S. Nuclear Regulatory Comission.

Gauld, I. C. (2003). MOX Cross-Section Libraries for ORIGEN-ARP, ORNL/TM-2003/2. UT-Battelle, LLC.

Gauld, I. C., Radulescu, G., Ilas, G., Murphy, B. D., Williams, M. L., \& Wiarda, D. (2011). Isotopic Depletion and Decay Methods and Analysis Capabilities in SCALE. Nuclear Technology, 174 (2), 169195.

Larsen, N. H. (1978). Core Design and Operating Data for Cycles 1 and 2 of Peach Bottom 2. General Electric Company, Nuclear Energy Engineering Division. Palo Alto, CA: Electric Power Research Institute.

Williams, M. L. (2011). Resonance Self-Shielding Methodologies in SCALE 6. Nuclear Technology, 174 (2), 149-168. 

APPENDIX A

DETAILED DATA REGARDING THE STORAGE OF WG-MOX FUEL 



\section{APPENDIX A. DETAILED DATA REGARDING THE STORAGE OF WG-MOX FUEL}

Most worldwide operational experience with MOX fuel pertains to RG-MOX. In order to provide more detailed information pertaining to the storage and disposal of WG-MOX, some additional figures have been generated. The data in these figures are identical to the data previously plotted, but the axes of some figures have been modified to provide more detail during selected times after discharge from the reactor. In order to avoid redundancy, the $50 \mathrm{GWd} / \mathrm{MTHM}$ data was plotted rather than the data for each discharge burnup (35, 40, 45, and $50 \mathrm{GWd} / \mathrm{MTHM})$. The data have been separated into sections for PWR and BWR fuel.

\section{A.1 Comparison of WG-MOX and UOX for PWR Fuel}

Table A1 shows a comparison of the UOX and WG-MOX decay heat for selected points after discharge for a burnup of $50 \mathrm{GWd} / \mathrm{MTHM}$ for PWR fuel.

Table A1. Decay heat and decay heat ratio for UOX and WG-MOX PWR fuel with a burnup of $50 \mathrm{GWd} / \mathrm{MTHM}$ at selected times after discharge

\begin{tabular}{cccc}
\hline \multirow{2}{*}{$\begin{array}{c}\text { Time after discharge } \\
\text { (days) }\end{array}$} & \multicolumn{3}{c}{ Decay heat } \\
\cline { 2 - 4 } & WG-MOX (kW/MTHM) & UOX $(\mathbf{k W / M T H M )}$ & MOX/UOX \\
\hline $\mathbf{0 . 0 1}$ & 597.2 & 615.1 & 0.97 \\
$\mathbf{1}$ & 182.3 & 181.6 & 1.00 \\
$\mathbf{1 0}$ & 83.8 & 78.0 & 1.07 \\
$\mathbf{1 0 0}$ & 33.7 & 27.9 & 1.20 \\
$\mathbf{1 0 0 0}$ & 5.7 & 5.1 & 1.13 \\
$\mathbf{1 0 0 0 0}$ & 1.6 & 1.3 & 1.27 \\
\hline
\end{tabular}

As shown, the decay heat of WG-MOX is similar to (but higher than) the decay heat of UOX. The decay heat for WG-MOX and UOX has been plotted over the entire period of interest after discharge (0 to over 10,000 days) in Fig. A1.

The decay heat from 500 to 3,000 days has been plotted for WG-MOX and UOX in Fig. A2. Figure A2 shows that the decay for WG-MOX is not significantly higher than that for UOX during the time that the fuel would be held in a spent fuel pool.

Depending on the heat load requirements of dry cask storage, WG-MOX may be required to cool longer in spent fuel pools than UOX fuel. After 5 years of cooling time (1825 days), the UOX decay heat has reduced to $2.8 \mathrm{~kW} / \mathrm{MTHM}$. The WG-MOX fuel reaches the same decay heat at 2065 days (240 days longer than UOX). Figure A2 shows that the decay heat of UOX and WG-MOX decays nonlinearly as a function of time, meaning that WG-MOX can be moved to dry cask storage less than 240 days after UOX if the heat load limit of the dry cask is higher than $2.8 \mathrm{~kW} / \mathrm{MTHM}$. If the heat load limit of the casks is lower, WG-MOX will need to remain in spent fuel pools more than 240 days after UOX can be moved to dry cask storage. 


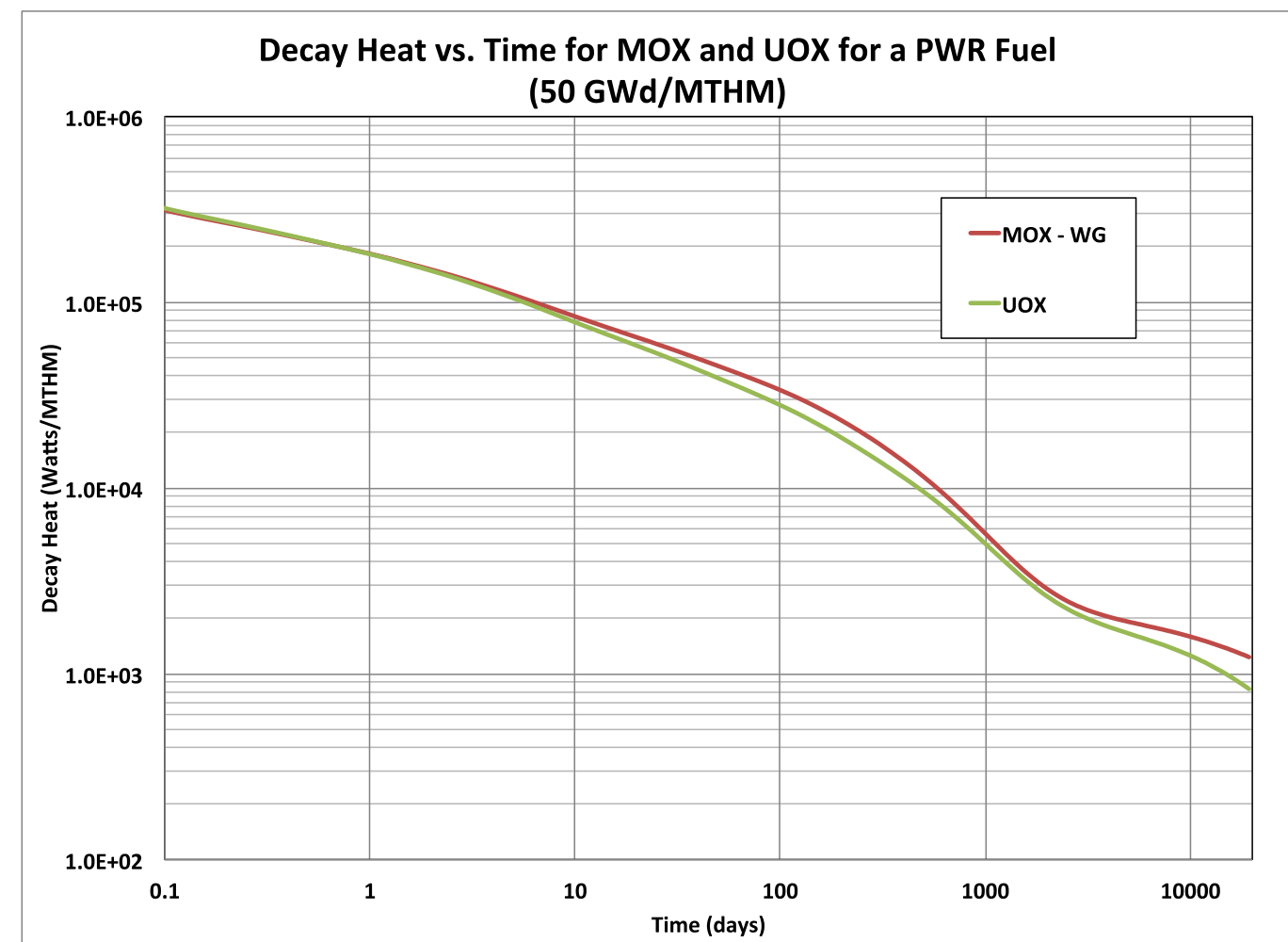

Fig. A1. Comparison of WG-MOX and UOX decay heat from 0 to 10,000 days after discharge for PWR

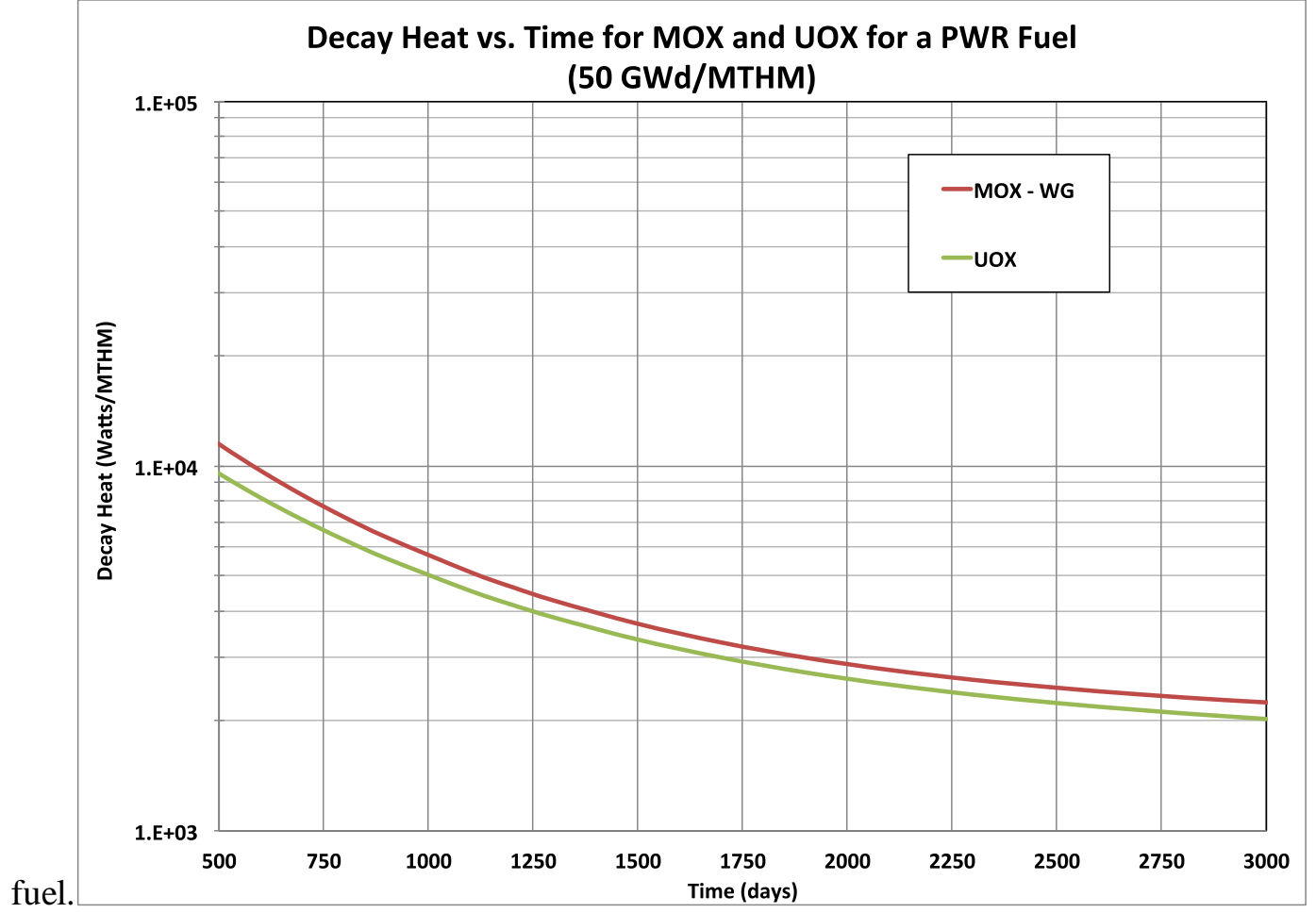

Fig. A2. Comparison of WG-MOX and UOX decay heat from 500 to 3,000 days after discharge for PWR fuel.

In addition to the comparison of the decay heat values, the decay heat ratio (WG-MOX/UOX) has been plotted as a function of time for the period just after discharge ( 0 to 5 days) and during long-term storage (10,000 to 18,000 days) in Figs. A3 and A4. Figure A3 shows that just after discharge, the decay heat of 
WG-MOX is very similar to UOX and the decay heat ratio ranges from 0.95 to 1.05 during the first 5 days with a crossover point (the point at which WG-MOX and UOX have equal decay heat) at $\sim 0.75$ days.

Figure A4 shows that the decay heat ratio long after discharge begins to diverge. The decay heat ratio ranges from $\sim 1.3$ to $\sim 1.5$ over 10,000 days after discharge (mainly due to the sharper decrease in decay heat of UOX when compared to WG-MOX). The divergence in the region long after discharge is of little importance because the absolute decay heat has decreased to 1-2 kW/MTHM during this region and will continue to decrease past 18,000 days. However, this difference may need to be considered for geologic disposal.

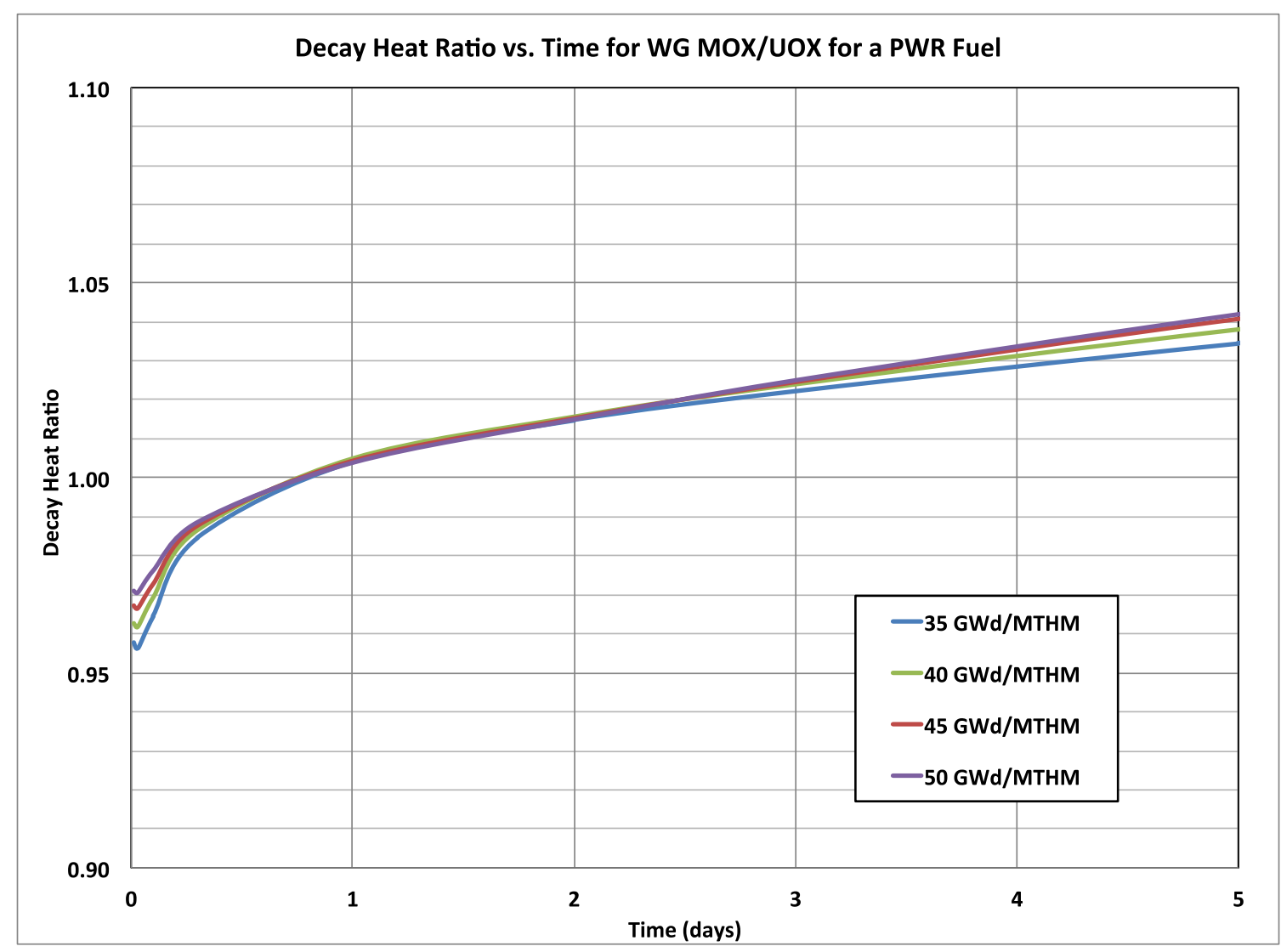

Fig. A3. Decay heat ratio for WG-MOX and UOX immediately after discharge for PWR fuel. 


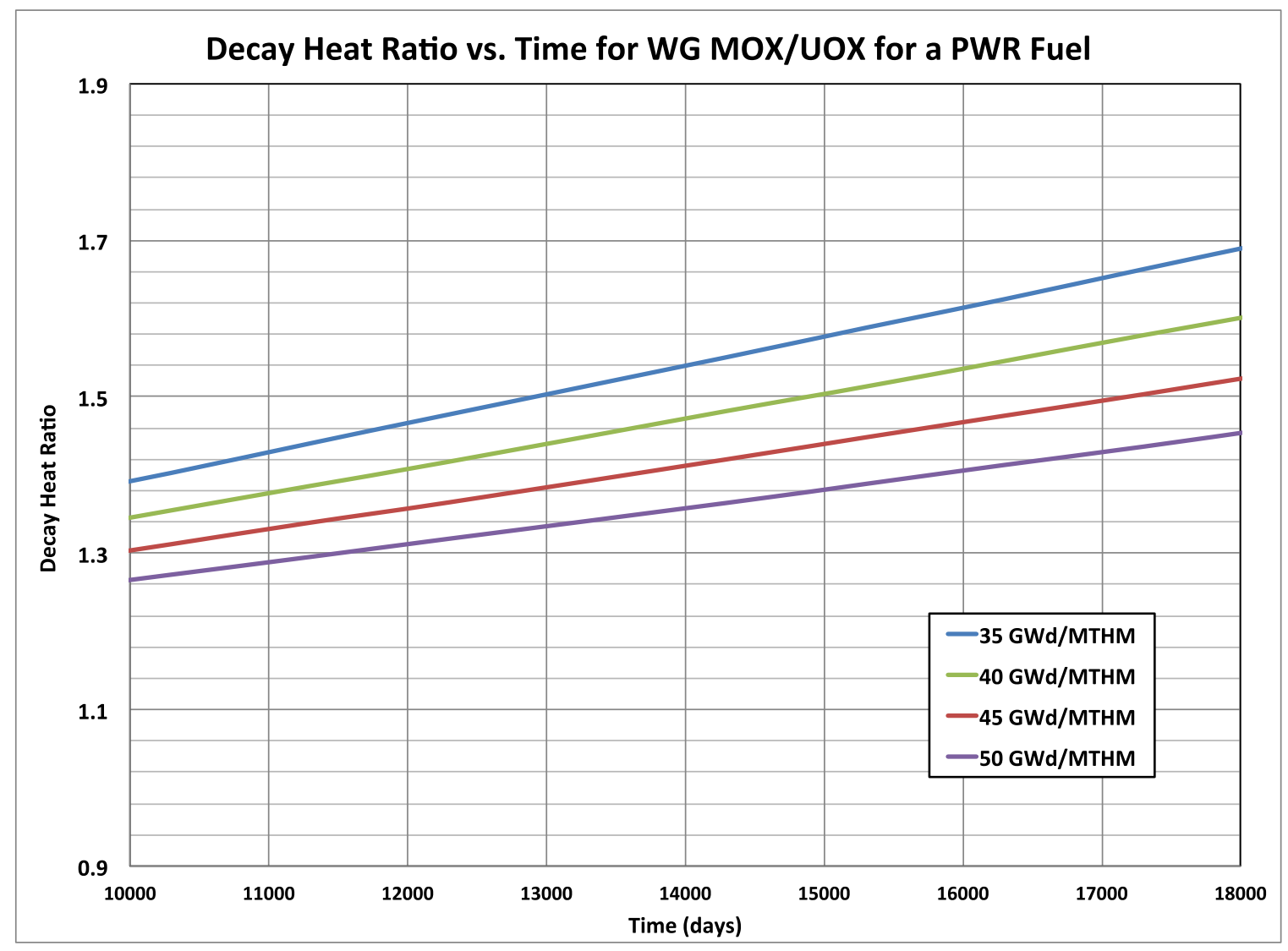

Fig. A4. Decay heat ratio for WG-MOX and UOX over 10,000 days after discharge for PWR fuel.

\section{A.2 Comparison of WG-MOX and UOX for BWR Fuel}

Table A2 shows a comparison of the UOX and WG-MOX decay heat for selected points after discharge for a burnup of $50 \mathrm{GWd} / \mathrm{MTHM}$ for BWR fuel. As shown, the decay heat for BWR fuel is very similar to PWR fuel for UOX and WG-MOX. The PWR fuel has a slightly higher heat load than the BWR fuel. Also, the decay heat ratio is similar for BWR and PWR fuel and shows very little difference when Tables A1 and A2 are compared.

Table A2. Decay heat and decay heat ratio for UOX and WG-MOX BWR fuel with a burnup of $50 \mathrm{GWd} / \mathrm{MTHM}$ at selected times after discharge

\begin{tabular}{cccc}
\hline \multirow{2}{*}{$\begin{array}{c}\text { Time after discharge } \\
(\mathbf{d a y s})\end{array}$} & \multicolumn{3}{c}{ Decay heat } \\
\cline { 2 - 4 } $\mathbf{0 . 0 1}$ & WG-MOX (kW/MTHM) & UOX (kW/MTHM) & MOX/UOX \\
\hline $\mathbf{1}$ & 587.1 & 610.6 & 0.96 \\
$\mathbf{1 0}$ & 177.3 & 179.6 & 0.99 \\
$\mathbf{1 0 0}$ & 82.1 & 77.4 & 1.06 \\
$\mathbf{1 0 0 0}$ & 32.7 & 27.4 & 1.19 \\
$\mathbf{1 0 0 0 0}$ & 5.5 & 4.9 & 1.12 \\
\hline
\end{tabular}


The decay heat for WG-MOX and UOX is plotted over the entire period of interest after discharge ( 0 to over 10,000 days) in Fig. A5. The decay heat for WG-MOX and UOX is similar from 0 to 10,000 days. At $\sim 3,000$ days after discharge, the decay heat of UOX decreases faster than that of WG-MOX, but at this point the decay heat is less than $2 \mathrm{~kW} / \mathrm{MTHM}$ for both UOX and WG-MOX.

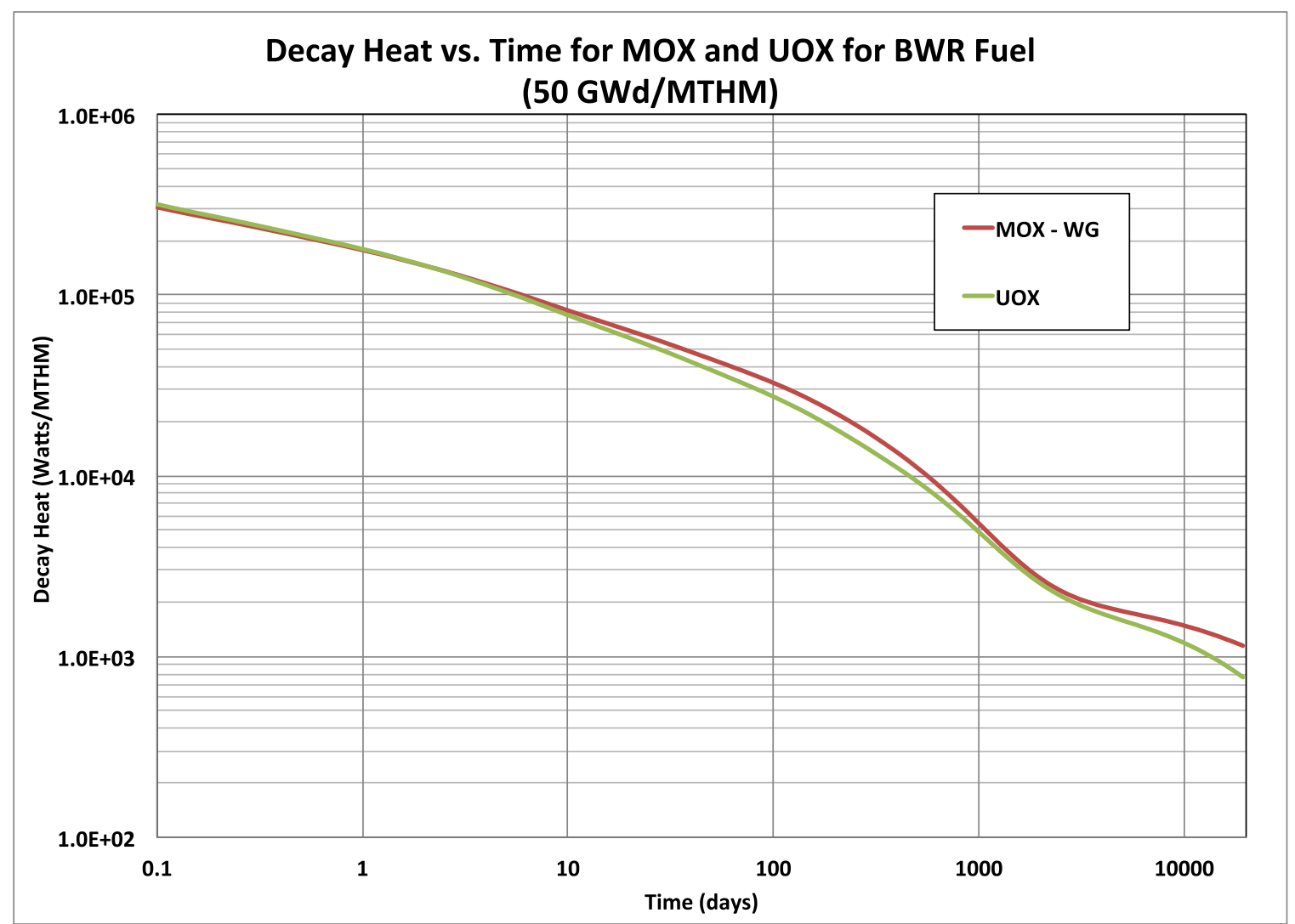

Fig. A5. Comparison of WG-MOX and UOX decay heat from 0 to 10,000 days after discharge for BWR fuel.

The decay heat during from 500 to 3000 days is plotted for WG-MOX and UOX in Fig. A6. Figure A6 shows that WG-MOX and UOX have similar decay heat during the time that the fuel would be held in a spent fuel pool.

Similar to PWR fuel, depending on the heat load requirements of dry cask storage, WG-MOX may be required to cool longer in spent fuel pools than UOX fuel. After 5 years of cooling time (1825 days), the UOX decay heat has reduced to $2.7 \mathrm{~kW} / \mathrm{MTHM}$ (compared to $2.8 \mathrm{~kW} / \mathrm{MTHM}$ for PWR fuel). The WGMOX fuel reaches the same decay heat at 2005 days - 180 days longer than UOX (compared to 240 days for PWR fuel).

The decay heat ratio (WG-MOX/UOX) for BWR fuel is plotted as a function of time for the period just after discharge ( 0 to 5 days) and during long-term storage (10,000 to 18,000 days) in Figs. A7 and A8. Figure A7 shows that just after discharge, the decay heat of WG-MOX is very similar to UOX and the decay heat ratio ranges from 0.95 to 1.03 during the first 5 days with a crossover point at $\sim 2.0$ days (as compared to 0.75 days for PWR fuel). 


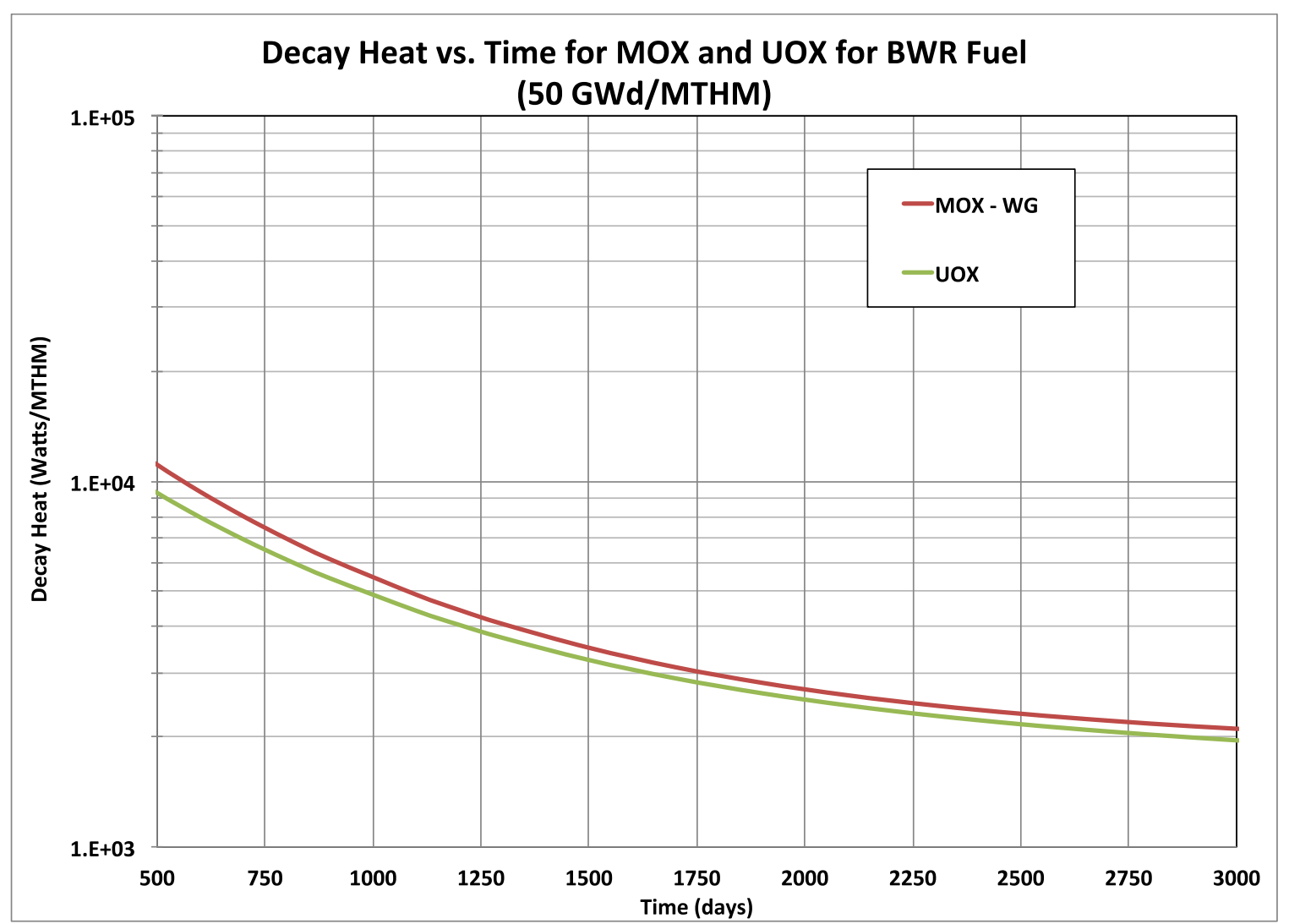

Fig. A6. Comparison of WG-MOX and UOX decay heat from 500 to 3,000 days after discharge for BWR fuel.

Figure A8 shows that the decay heat ratio long after discharge begins to diverge. The decay heat ratio ranges from $\sim 1.3$ to $\sim 1.5$ over 10,000 days after discharge due to the sharper decrease in decay heat of UOX when compared to WG-MOX. The divergence in the region long after discharge is of little importance because the absolute decay heat has decreased to 1-2 kW/MTHM during this region and will continue to decrease past 18,000 days. 


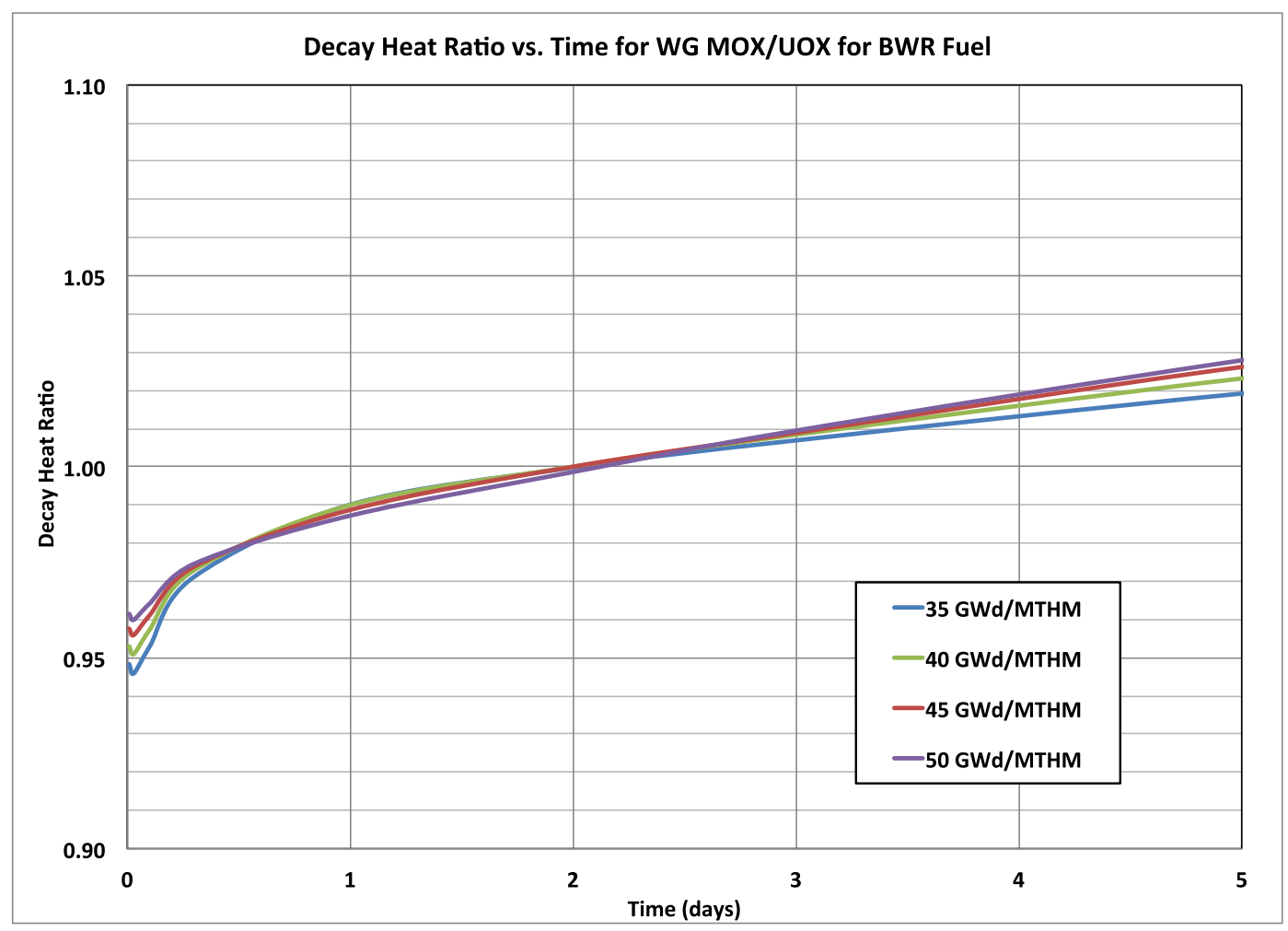

Fig. A7. Decay heat ratio for WG-MOX and UOX immediately after discharge for BWR fuel.

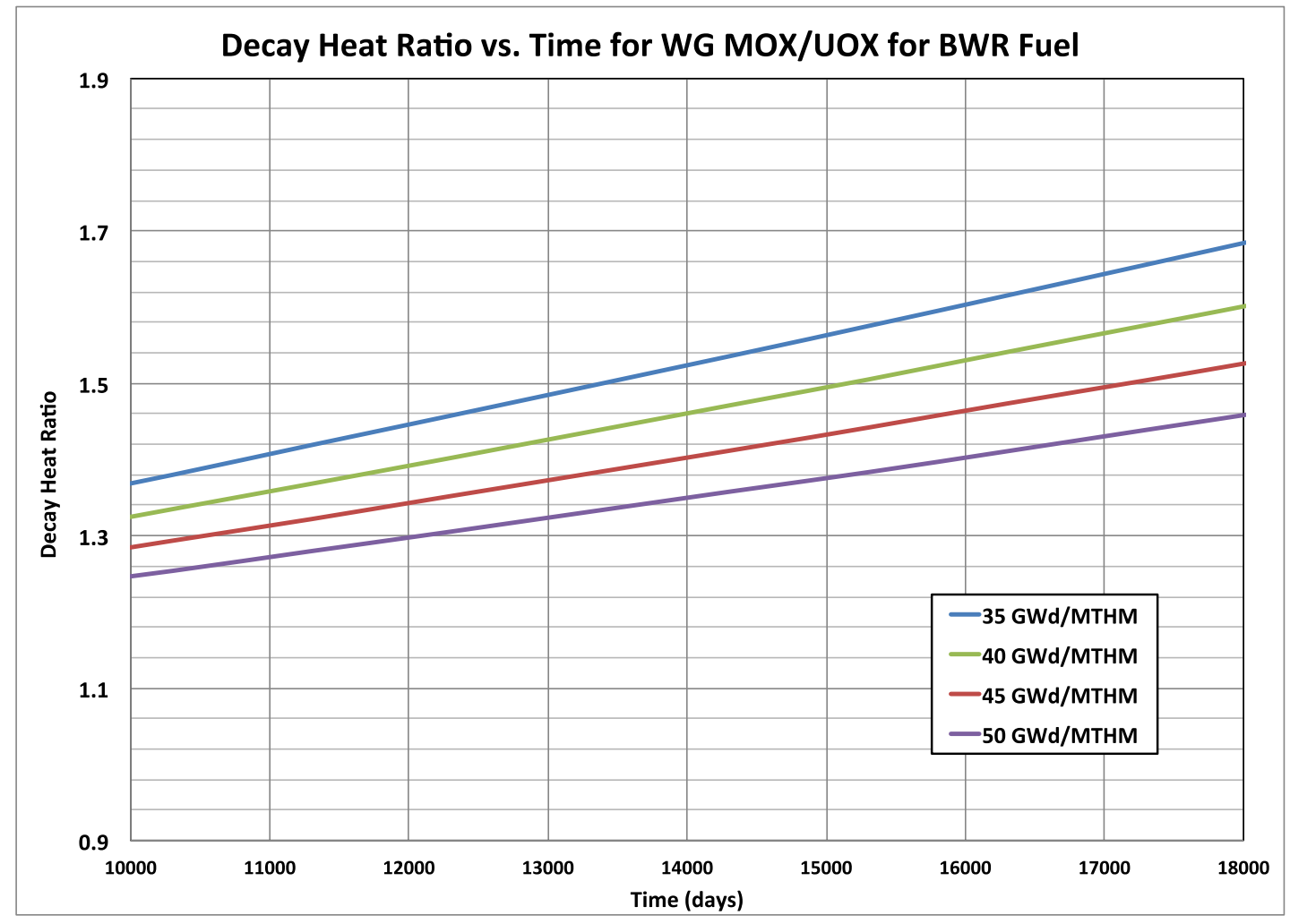

Fig. A8. Decay heat ratio for WG-MOX and UOX over 10,000 days after discharge for BWR fuel. 

APPENDIX B

RAW DATA 



\section{APPENDIX B. RAW DATA}

In the interest of providing information necessary for secondary analyses, the raw data used to generate the figures in this document have been included. The decay heat data in Table B1 and Table B2 are given in units of W/MTHM arranged in three major columns for UOX, RG-MOX, and WG-MOX. In each fueltype column, there are four sub-columns for discharge burnups of 35, 40, 45, and $50 \mathrm{GWd} / \mathrm{MTHM}$. The time after discharge is given in the leftmost column. 
Table B1. Decay heat data as a function of time after shutdown of PWR fuel

\begin{tabular}{|c|c|c|c|c|c|c|c|c|c|c|c|c|}
\hline \multirow{2}{*}{ Time } & \multicolumn{4}{|c|}{ UOX } & \multicolumn{4}{|c|}{ RG-MOX } & \multicolumn{4}{|c|}{ WG-MOX } \\
\hline & 35 GWd & 40 GWd & 45 GWd & 50 GWd & 35 GWd & 40 GWd & 45 GWd & 50 GWd & 35 GWd & 40 GWd & 45 GWd & 50 GWd \\
\hline 0.01 & $4.308 \mathrm{E}+05$ & $4.920 \mathrm{E}+05$ & $5.535 \mathrm{E}+05$ & $1 \mathrm{E}+05$ & $4.176 \mathrm{E}+05$ & $4.780 \mathrm{E}+05$ & $5.389 \mathrm{E}+05$ & $95 \mathrm{E}+05$ & $4.126 \mathrm{E}+05$ & $4.737 \mathrm{E}+05$ & $5.353 \mathrm{E}+05$ & $5.972 \mathrm{E}+05$ \\
\hline 0.03 & $3.185 \mathrm{E}+05$ & $3.639 \mathrm{E}+05$ & $4.096 \mathrm{E}+05$ & $4.553 \mathrm{E}+05$ & $3.104 \mathrm{E}+05$ & $3.554 \mathrm{E}+05$ & $4.007 \mathrm{E}+05$ & $4.458 \mathrm{E}+05$ & $3.046 \mathrm{E}+05$ & $3.500 \mathrm{E}+05$ & $3.959 \mathrm{E}+05$ & $4.419 \mathrm{E}+05$ \\
\hline 0.10 & $2.226 \mathrm{E}+05$ & $2.549 \mathrm{E}+05$ & $2.876 \mathrm{E}+05$ & $3.204 \mathrm{E}+05$ & $2.209 \mathrm{E}+05$ & $2.530 \mathrm{E}+05$ & $2.854 \mathrm{E}+05$ & $3.177 \mathrm{E}+05$ & $2.147 \mathrm{E}+05$ & $2.471 \mathrm{E}+05$ & $2.798 \mathrm{E}+05$ & $3.128 \mathrm{E}+05$ \\
\hline 0.30 & $1.688 \mathrm{E}+05$ & $1.943 \mathrm{E}+05$ & $2.203 \mathrm{E}+05$ & $2.465 \mathrm{E}+05$ & $1.722 \mathrm{E}+05$ & $1.975 \mathrm{E}+05$ & $2.230 \mathrm{E}+05$ & $2.484 \mathrm{E}+05$ & $1.662 \mathrm{E}+05$ & $1.917 \mathrm{E}+05$ & $2.176 \mathrm{E}+05$ & $2.437 \mathrm{E}+05$ \\
\hline 1.00 & $1.228 \mathrm{E}+05$ & $1.420 \mathrm{E}+05$ & $1.617 \mathrm{E}+05$ & $1.816 \mathrm{E}+05$ & $1.294 \mathrm{E}+05$ & $1.486 \mathrm{E}+05$ & $1.680 \mathrm{E}+05$ & $1.874 \mathrm{E}+05$ & $1.233 \mathrm{E}+05$ & $1.427 \mathrm{E}+05$ & $1.624 \mathrm{E}+05$ & $1.823 \mathrm{E}+05$ \\
\hline 2.00 & $9.934 \mathrm{E}+04$ & $1.150 \mathrm{E}+05$ & $1.311 \mathrm{E}+05$ & $1.473 \mathrm{E}+05$ & $1.074 \mathrm{E}+05$ & $1.233 \mathrm{E}+05$ & $1.394 \mathrm{E}+05$ & $1.555 \mathrm{E}+05$ & $1.008 \mathrm{E}+05$ & $1.168 \mathrm{E}+05$ & $1.331 \mathrm{E}+05$ & $1.495 \mathrm{E}+05$ \\
\hline 3.00 & $8.648 \mathrm{E}+04$ & $1.001 \mathrm{E}+05$ & $1.140 \mathrm{E}+05$ & $1.281 \mathrm{E}+05$ & $9.542 \mathrm{E}+04$ & $1.096 \mathrm{E}+05$ & $1.239 \mathrm{E}+05$ & $1.381 \mathrm{E}+05$ & $8.840 \mathrm{E}+04$ & $1.025 \mathrm{E}+05$ & $1.168 \mathrm{E}+05$ & $1.313 \mathrm{E}+05$ \\
\hline 5.00 & $7.120 \mathrm{E}+04$ & $8.228 \mathrm{E}+04$ & $9.357 \mathrm{E}+04$ & $1.050 \mathrm{E}+05$ & $8.129 \mathrm{E}+04$ & $9.330 \mathrm{E}+04$ & $1.054 \mathrm{E}+05$ & $1.175 \mathrm{E}+05$ & $7.365 \mathrm{E}+04$ & $8.541 \mathrm{E}+04$ & $9.738 \mathrm{E}+04$ & $1.094 \mathrm{E}+05$ \\
\hline 7.00 & $6.195 \mathrm{E}+04$ & $7.151 \mathrm{E}+04$ & $8.123 \mathrm{E}+04$ & $9.104 \mathrm{E}+04$ & $7.271 \mathrm{E}+04$ & $8.342 \mathrm{E}+04$ & $9.419 \mathrm{E}+04$ & $1.049 \mathrm{E}+05$ & $6.473 \mathrm{E}+04$ & $7.509 \mathrm{E}+04$ & $8.562 E+04$ & $9.621 \mathrm{E}+04$ \\
\hline 10.00 & $5.323 \mathrm{E}+04$ & $6.140 \mathrm{E}+04$ & $6.969 \mathrm{E}+04$ & $7.803 \mathrm{E}+04$ & $6.453 \mathrm{E}+04$ & $7.400 \mathrm{E}+04$ & $8.351 \mathrm{E}+04$ & $9.299 \mathrm{E}+04$ & $5.633 \mathrm{E}+04$ & $6.538 \mathrm{E}+04$ & $7.457 \mathrm{E}+04$ & $8.380 \mathrm{E}+04$ \\
\hline 12.00 & $4.928 \mathrm{E}+04$ & $5.684 \mathrm{E}+04$ & $6.450 \mathrm{E}+04$ & $7.220 \mathrm{E}+04$ & $6.077 \mathrm{E}+04$ & $6.968 \mathrm{E}+04$ & $7.861 \mathrm{E}+04$ & $8.751 \mathrm{E}+04$ & $5.252 \mathrm{E}+04$ & $6.098 \mathrm{E}+04$ & $6.958 \mathrm{E}+04$ & $7.820 \mathrm{E}+04$ \\
\hline 14.00 & $4.620 \mathrm{E}+04$ & $5.328 \mathrm{E}+04$ & $6.046 \mathrm{E}+04$ & $6.769 \mathrm{E}+04$ & $5.780 \mathrm{E}+04$ & $6.627 \mathrm{E}+04$ & $7.475 \mathrm{E}+04$ & $8.320 \mathrm{E}+04$ & $4.955 \mathrm{E}+04$ & $5.756 \mathrm{E}+04$ & $6.568 \mathrm{E}+04$ & $7.383 \mathrm{E}+04$ \\
\hline 16.00 & $4.370 \mathrm{E}+04$ & $5.040 \mathrm{E}+04$ & $5.720 \mathrm{E}+04$ & $6.403 \mathrm{E}+04$ & $5.537 \mathrm{E}+04$ & $6.348 \mathrm{E}+04$ & $7.159 \mathrm{E}+04$ & $7.967 \mathrm{E}+04$ & $4.714 \mathrm{E}+04$ & $5.477 \mathrm{E}+04$ & $6.252 \mathrm{E}+04$ & $7.028 \mathrm{E}+04$ \\
\hline 18.00 & $4.160 \mathrm{E}+04$ & $4.799 \mathrm{E}+04$ & $5.447 \mathrm{E}+04$ & $6.099 \mathrm{E}+04$ & $5.332 \mathrm{E}+04$ & $6.112 \mathrm{E}+04$ & $6.892 \mathrm{E}+04$ & $7.669 \mathrm{E}+04$ & $4.511 \mathrm{E}+04$ & $5.244 \mathrm{E}+04$ & $5.986 \mathrm{E}+04$ & $6.731 \mathrm{E}+04$ \\
\hline 20.00 & $3.980 \mathrm{E}+04$ & $4.592 \mathrm{E}+04$ & $5.213 \mathrm{E}+04$ & $5.837 \mathrm{E}+04$ & $5.154 \mathrm{E}+04$ & $5.907 \mathrm{E}+04$ & $6.661 \mathrm{E}+04$ & $7.410 \mathrm{E}+04$ & $4.337 \mathrm{E}+04$ & $5.042 \mathrm{E}+04$ & $5.758 \mathrm{E}+04$ & $6.475 \mathrm{E}+04$ \\
\hline 22.00 & $3.822 \mathrm{E}+04$ & $4.411 \mathrm{E}+04$ & $5.008 \mathrm{E}+04$ & $5.609 \mathrm{E}+04$ & $4.997 \mathrm{E}+04$ & $5.727 \mathrm{E}+04$ & $6.456 \mathrm{E}+04$ & $7.182 \mathrm{E}+04$ & $4.184 \mathrm{E}+04$ & $4.866 \mathrm{E}+04$ & $5.558 \mathrm{E}+04$ & $6.250 \mathrm{E}+04$ \\
\hline 24.00 & $3.681 \mathrm{E}+04$ & $4.249 \mathrm{E}+04$ & $4.826 \mathrm{E}+04$ & $5.406 \mathrm{E}+04$ & $4.856 \mathrm{E}+04$ & $5.565 \mathrm{E}+04$ & $6.274 \mathrm{E}+04$ & $6.978 \mathrm{E}+04$ & $4.048 \mathrm{E}+04$ & $4.709 \mathrm{E}+04$ & $5.379 \mathrm{E}+04$ & $6.050 \mathrm{E}+04$ \\
\hline 26.00 & $3.555 \mathrm{E}+04$ & $4.105 \mathrm{E}+04$ & $4.662 \mathrm{E}+04$ & $5.224 \mathrm{E}+04$ & $4.728 \mathrm{E}+04$ & $5.419 \mathrm{E}+04$ & $6.108 \mathrm{E}+04$ & $6.794 \mathrm{E}+04$ & $3.925 \mathrm{E}+04$ & $4.567 \mathrm{E}+04$ & $5.218 \mathrm{E}+04$ & $5.870 \mathrm{E}+04$ \\
\hline 28.00 & $3.440 \mathrm{E}+04$ & $3.973 \mathrm{E}+04$ & $4.514 \mathrm{E}+04$ & $5.059 \mathrm{E}+04$ & $4.612 \mathrm{E}+04$ & $5.285 \mathrm{E}+04$ & $5.957 \mathrm{E}+04$ & $6.626 \mathrm{E}+04$ & $3.814 \mathrm{E}+04$ & $4.438 \mathrm{E}+04$ & $5.072 \mathrm{E}+04$ & $5.706 \mathrm{E}+04$ \\
\hline 30.00 & $3.335 \mathrm{E}+04$ & $3.853 \mathrm{E}+04$ & $4.379 \mathrm{E}+04$ & $4.908 \mathrm{E}+04$ & $4.505 \mathrm{E}+04$ & $5.162 \mathrm{E}+04$ & $5.819 \mathrm{E}+04$ & $6.471 \mathrm{E}+04$ & $3.712 \mathrm{E}+04$ & $4.321 \mathrm{E}+04$ & $4.938 \mathrm{E}+04$ & $5.556 \mathrm{E}+04$ \\
\hline 40.00 & $2.921 \mathrm{E}+04$ & $3.380 \mathrm{E}+04$ & $3.845 \mathrm{E}+04$ & $4.314 \mathrm{E}+04$ & $4.075 \mathrm{E}+04$ & $4.669 \mathrm{E}+04$ & $5.261 \mathrm{E}+04$ & $5.850 \mathrm{E}+04$ & $3.306 \mathrm{E}+04$ & $3.852 \mathrm{E}+04$ & $4.405 \mathrm{E}+04$ & $4.959 \mathrm{E}+04$ \\
\hline 60.00 & $2.406 \mathrm{E}+04$ & $2.792 \mathrm{E}+04$ & $3.184 \mathrm{E}+04$ & $3.580 \mathrm{E}+04$ & $3.513 \mathrm{E}+04$ & $4.025 \mathrm{E}+04$ & $4.536 \mathrm{E}+04$ & $5.043 \mathrm{E}+04$ & $2.791 \mathrm{E}+04$ & $3.258 \mathrm{E}+04$ & $3.731 \mathrm{E}+04$ & $4.204 \mathrm{E}+04$ \\
\hline 80.00 & $2.085 \mathrm{E}+04$ & $2.425 \mathrm{E}+04$ & $2.772 \mathrm{E}+04$ & $3.123 \mathrm{E}+04$ & $3.138 \mathrm{E}+04$ & $3.597 \mathrm{E}+04$ & $4.055 \mathrm{E}+04$ & $4.510 \mathrm{E}+04$ & $2.462 \mathrm{E}+04$ & $2.878 \mathrm{E}+04$ & $3.300 \mathrm{E}+04$ & $3.722 \mathrm{E}+04$ \\
\hline
\end{tabular}


Table B1. Decay heat data as a function of time after shutdown of PWR fuel (continued)

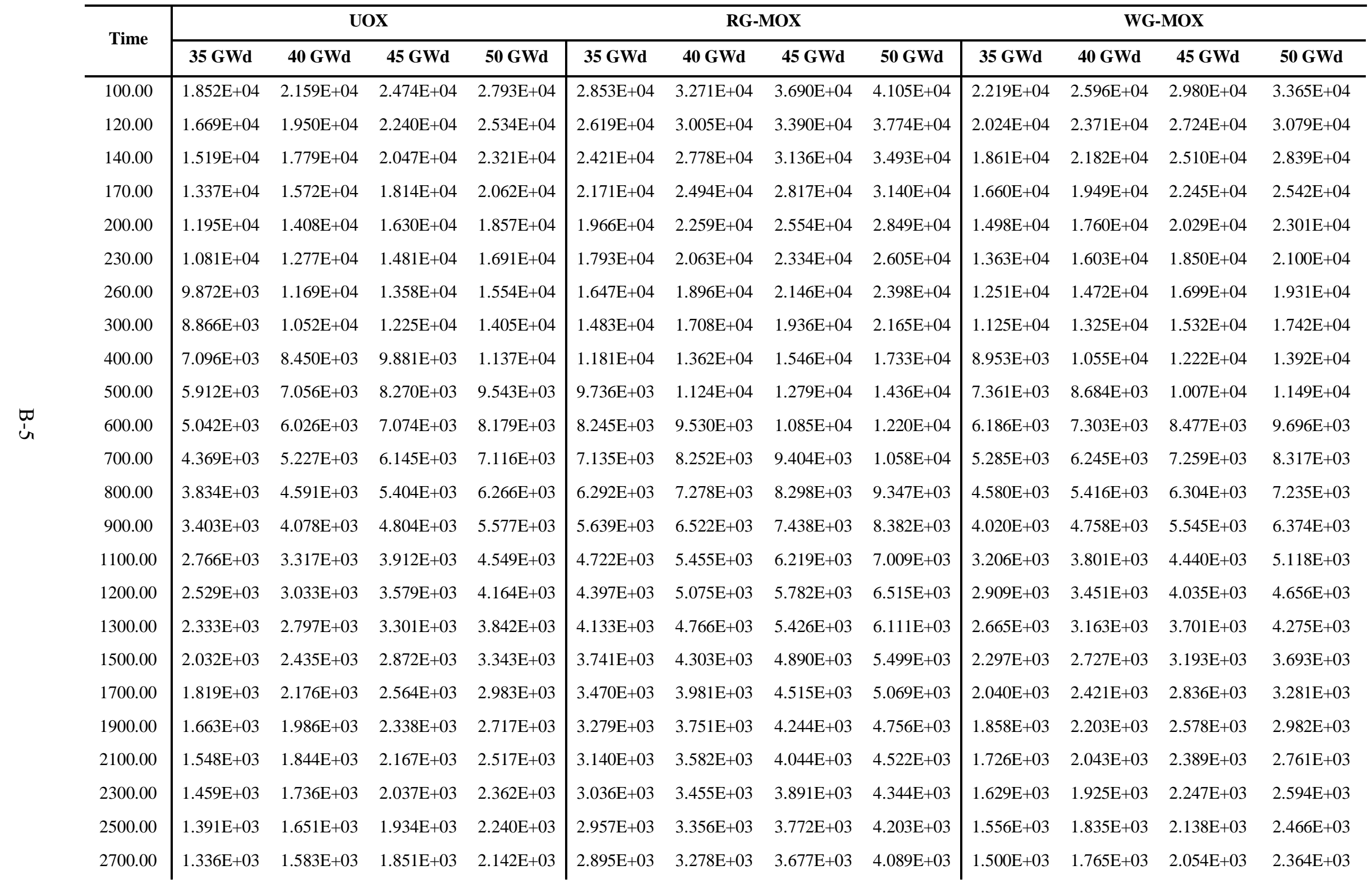


Table B1. Decay heat data as a function of time after shutdown of PWR fuel (continued)

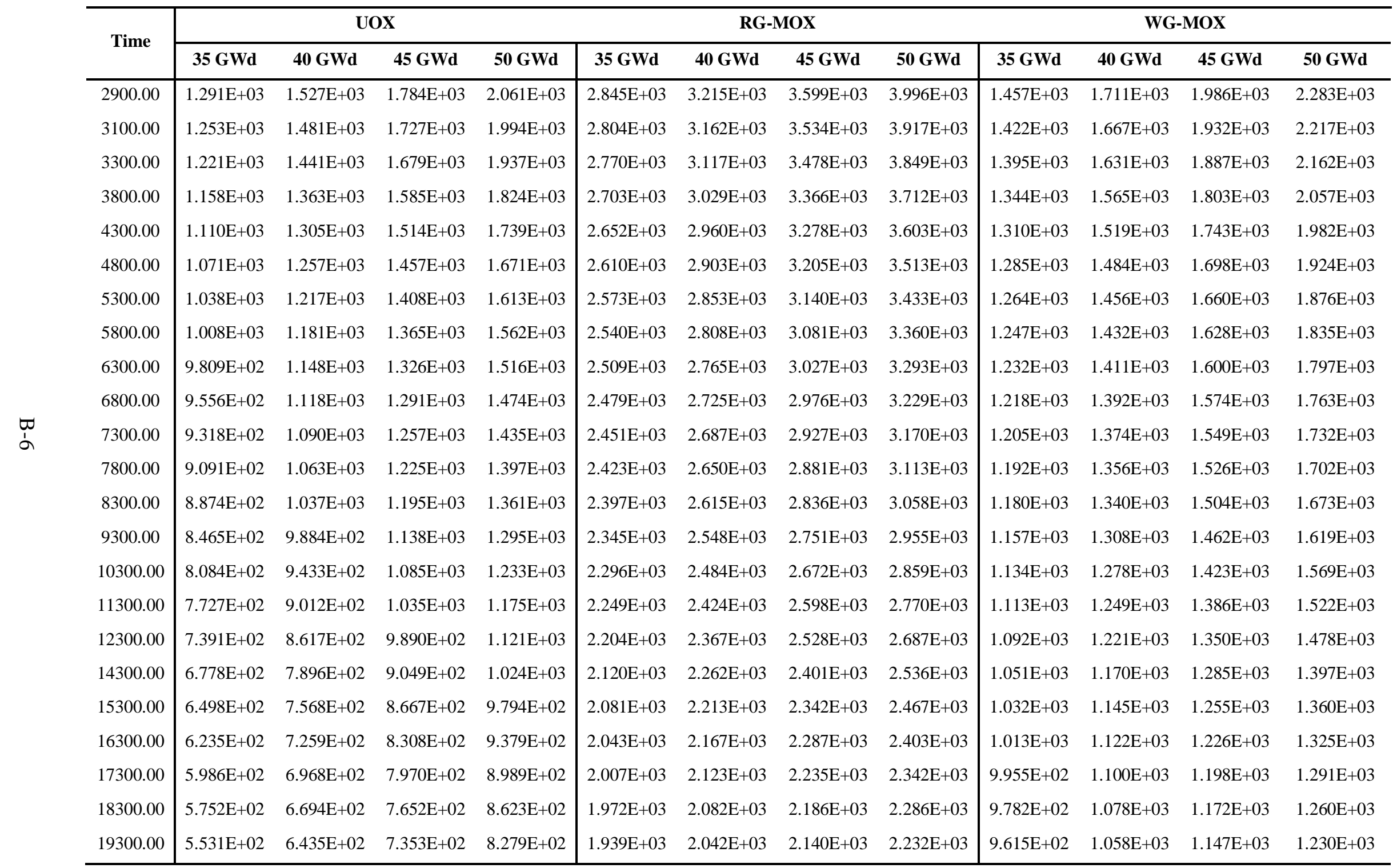


Table B2. Decay heat data as a function of time after shutdown for BWR fuel

\begin{tabular}{|c|c|c|c|c|c|c|c|c|c|c|c|c|}
\hline \multirow{2}{*}{ Time } & \multicolumn{4}{|c|}{ UOX } & \multicolumn{4}{|c|}{ RG-MOX } & \multicolumn{4}{|c|}{ WG-MOX } \\
\hline & 35 GWd & 40 GWd & 45 GWd & 50 GWd & 35 GWd & 40 GWd & 45 GWd & 50 GWd & 35 GWd & 40 GWd & 45 GWd & 50 GWd \\
\hline 0.01 & $4.275 \mathrm{E}+05$ & $4.882 \mathrm{E}+05$ & $5.493 \mathrm{E}+05$ & $6.106 \mathrm{E}+05$ & $4.098 \mathrm{E}+05$ & $4.689 \mathrm{E}+05$ & $5.283 \mathrm{E}+05$ & $5.878 \mathrm{E}+05$ & $4.054 \mathrm{E}+05$ & $4.653 \mathrm{E}+05$ & $5.260 \mathrm{E}+05$ & $5.871 \mathrm{E}+05$ \\
\hline 0.03 & $3.159 \mathrm{E}+05$ & $3.610 \mathrm{E}+05$ & $4.063 \mathrm{E}+05$ & $4.519 \mathrm{E}+05$ & $3.040 \mathrm{E}+05$ & $3.480 \mathrm{E}+05$ & $3.921 \mathrm{E}+05$ & $4.363 \mathrm{E}+05$ & $2.988 \mathrm{E}+05$ & $3.433 \mathrm{E}+05$ & $3.884 \mathrm{E}+05$ & $4.338 \mathrm{E}+05$ \\
\hline 0.10 & $2.204 \mathrm{E}+05$ & $2.525 \mathrm{E}+05$ & $2.849 \mathrm{E}+05$ & $3.177 \mathrm{E}+05$ & $2.156 \mathrm{E}+05$ & $2.469 \mathrm{E}+05$ & $2.784 \mathrm{E}+05$ & $3.099 \mathrm{E}+05$ & $2.100 \mathrm{E}+05$ & $2.417 \mathrm{E}+05$ & $2.738 \mathrm{E}+05$ & $3.063 \mathrm{E}+05$ \\
\hline 0.30 & $1.665 \mathrm{E}+05$ & $1.918 \mathrm{E}+05$ & $2.177 \mathrm{E}+05$ & $2.439 \mathrm{E}+05$ & $1.672 \mathrm{E}+05$ & $1.916 \mathrm{E}+05$ & $2.163 \mathrm{E}+05$ & $2.411 \mathrm{E}+05$ & $1.617 \mathrm{E}+05$ & $1.866 \mathrm{E}+05$ & $2.120 \mathrm{E}+05$ & $2.377 \mathrm{E}+05$ \\
\hline 1.00 & $1.207 \mathrm{E}+05$ & $1.398 \mathrm{E}+05$ & $1.595 \mathrm{E}+05$ & $1.796 \mathrm{E}+05$ & $1.251 \mathrm{E}+05$ & $1.436 \mathrm{E}+05$ & $1.623 \mathrm{E}+05$ & $1.811 \mathrm{E}+05$ & $1.195 \mathrm{E}+05$ & $1.384 \mathrm{E}+05$ & $1.577 \mathrm{E}+05$ & $1.773 \mathrm{E}+05$ \\
\hline 2.00 & $9.772 \mathrm{E}+04$ & $1.133 \mathrm{E}+05$ & $1.293 \mathrm{E}+05$ & $1.457 \mathrm{E}+05$ & $1.038 \mathrm{E}+05$ & $1.192 \mathrm{E}+05$ & $1.347 \mathrm{E}+05$ & $1.504 \mathrm{E}+05$ & $9.770 \mathrm{E}+04$ & $1.133 \mathrm{E}+05$ & $1.293 \mathrm{E}+05$ & $1.455 \mathrm{E}+05$ \\
\hline 3.00 & $8.521 \mathrm{E}+04$ & $9.871 \mathrm{E}+04$ & $1.126 \mathrm{E}+05$ & $1.267 \mathrm{E}+05$ & $9.237 \mathrm{E}+04$ & $1.060 \mathrm{E}+05$ & $1.199 \mathrm{E}+05$ & $1.338 \mathrm{E}+05$ & $8.580 \mathrm{E}+04$ & $9.954 \mathrm{E}+04$ & $1.136 \mathrm{E}+05$ & $1.279 \mathrm{E}+05$ \\
\hline 5.00 & $7.037 \mathrm{E}+04$ & $8.134 \mathrm{E}+04$ & $9.256 \mathrm{E}+04$ & $1.040 \mathrm{E}+05$ & $7.896 \mathrm{E}+04$ & $9.060 \mathrm{E}+04$ & $1.024 \mathrm{E}+05$ & $1.142 \mathrm{E}+05$ & $7.172 \mathrm{E}+04$ & $8.322 \mathrm{E}+04$ & $9.498 \mathrm{E}+04$ & $1.069 \mathrm{E}+05$ \\
\hline 7.00 & $6.136 \mathrm{E}+04$ & $7.082 \mathrm{E}+04$ & $8.046 \mathrm{E}+04$ & $9.021 \mathrm{E}+04$ & $7.078 \mathrm{E}+04$ & $8.118 \mathrm{E}+04$ & $9.168 \mathrm{E}+04$ & $1.022 \mathrm{E}+05$ & $6.317 \mathrm{E}+04$ & $7.331 \mathrm{E}+04$ & $8.367 \mathrm{E}+04$ & $9.416 \mathrm{E}+04$ \\
\hline 10.00 & $5.282 \mathrm{E}+04$ & $6.089 \mathrm{E}+04$ & $6.908 \mathrm{E}+04$ & $7.735 \mathrm{E}+04$ & $6.291 \mathrm{E}+04$ & $7.212 \mathrm{E}+04$ & $8.141 \mathrm{E}+04$ & $9.071 \mathrm{E}+04$ & $5.505 \mathrm{E}+04$ & $6.392 \mathrm{E}+04$ & $7.297 \mathrm{E}+04$ & $8.211 \mathrm{E}+04$ \\
\hline 12.00 & $4.893 \mathrm{E}+04$ & $5.639 \mathrm{E}+04$ & $6.394 \mathrm{E}+04$ & $7.157 \mathrm{E}+04$ & $5.925 \mathrm{E}+04$ & $6.792 \mathrm{E}+04$ & $7.665 \mathrm{E}+04$ & $8.539 \mathrm{E}+04$ & $5.134 \mathrm{E}+04$ & $5.963 \mathrm{E}+04$ & $6.809 \mathrm{E}+04$ & $7.663 \mathrm{E}+04$ \\
\hline 14.00 & $4.588 \mathrm{E}+04$ & $5.286 \mathrm{E}+04$ & $5.994 \mathrm{E}+04$ & $6.707 \mathrm{E}+04$ & $5.635 \mathrm{E}+04$ & $6.459 \mathrm{E}+04$ & $7.288 \mathrm{E}+04$ & $8.118 \mathrm{E}+04$ & $4.843 \mathrm{E}+04$ & $5.627 \mathrm{E}+04$ & $6.426 \mathrm{E}+04$ & $7.234 \mathrm{E}+04$ \\
\hline 16.00 & $4.339 \mathrm{E}+04$ & $5.000 \mathrm{E}+04$ & $5.669 \mathrm{E}+04$ & $6.343 \mathrm{E}+04$ & $5.396 \mathrm{E}+04$ & $6.185 \mathrm{E}+04$ & $6.978 \mathrm{E}+04$ & $7.771 \mathrm{E}+04$ & $4.606 \mathrm{E}+04$ & $5.353 \mathrm{E}+04$ & $6.115 \mathrm{E}+04$ & $6.884 \mathrm{E}+04$ \\
\hline 18.00 & $4.131 \mathrm{E}+04$ & $4.760 \mathrm{E}+04$ & $5.397 \mathrm{E}+04$ & $6.039 \mathrm{E}+04$ & $5.194 \mathrm{E}+04$ & $5.952 \mathrm{E}+04$ & $6.715 \mathrm{E}+04$ & $7.477 \mathrm{E}+04$ & $4.406 \mathrm{E}+04$ & $5.122 \mathrm{E}+04$ & $5.853 \mathrm{E}+04$ & $6.590 \mathrm{E}+04$ \\
\hline 20.00 & $3.951 \mathrm{E}+04$ & $4.553 \mathrm{E}+04$ & $5.164 \mathrm{E}+04$ & $5.778 \mathrm{E}+04$ & $5.018 \mathrm{E}+04$ & $5.750 \mathrm{E}+04$ & $6.487 \mathrm{E}+04$ & $7.223 \mathrm{E}+04$ & $4.233 \mathrm{E}+04$ & $4.923 \mathrm{E}+04$ & $5.627 \mathrm{E}+04$ & $6.336 \mathrm{E}+04$ \\
\hline 22.00 & $3.793 \mathrm{E}+04$ & $4.372 \mathrm{E}+04$ & $4.959 \mathrm{E}+04$ & $5.549 \mathrm{E}+04$ & $4.863 \mathrm{E}+04$ & $5.572 \mathrm{E}+04$ & $6.285 \mathrm{E}+04$ & $6.998 \mathrm{E}+04$ & $4.082 \mathrm{E}+04$ & $4.748 \mathrm{E}+04$ & $5.428 \mathrm{E}+04$ & $6.113 \mathrm{E}+04$ \\
\hline 24.00 & $3.652 \mathrm{E}+04$ & $4.211 \mathrm{E}+04$ & $4.777 \mathrm{E}+04$ & $5.346 \mathrm{E}+04$ & $4.724 \mathrm{E}+04$ & $5.412 \mathrm{E}+04$ & $6.105 \mathrm{E}+04$ & $6.796 \mathrm{E}+04$ & $3.947 \mathrm{E}+04$ & $4.593 \mathrm{E}+04$ & $5.251 \mathrm{E}+04$ & $5.915 \mathrm{E}+04$ \\
\hline 26.00 & $3.525 \mathrm{E}+04$ & $4.066 \mathrm{E}+04$ & $4.613 \mathrm{E}+04$ & $5.164 \mathrm{E}+04$ & $4.598 \mathrm{E}+04$ & $5.268 \mathrm{E}+04$ & $5.941 \mathrm{E}+04$ & $6.614 \mathrm{E}+04$ & $3.826 \mathrm{E}+04$ & $4.452 \mathrm{E}+04$ & $5.092 \mathrm{E}+04$ & $5.736 \mathrm{E}+04$ \\
\hline 28.00 & $3.411 \mathrm{E}+04$ & $3.934 \mathrm{E}+04$ & $4.465 \mathrm{E}+04$ & $4.999 \mathrm{E}+04$ & $4.483 \mathrm{E}+04$ & $5.136 \mathrm{E}+04$ & $5.792 \mathrm{E}+04$ & $6.447 \mathrm{E}+04$ & $3.715 \mathrm{E}+04$ & $4.325 \mathrm{E}+04$ & $4.947 \mathrm{E}+04$ & $5.573 \mathrm{E}+04$ \\
\hline 30.00 & $3.306 \mathrm{E}+04$ & $3.814 \mathrm{E}+04$ & $4.330 \mathrm{E}+04$ & $4.848 \mathrm{E}+04$ & $4.377 \mathrm{E}+04$ & $5.014 \mathrm{E}+04$ & $5.655 \mathrm{E}+04$ & $6.295 \mathrm{E}+04$ & $3.614 \mathrm{E}+04$ & $4.208 \mathrm{E}+04$ & $4.814 \mathrm{E}+04$ & $5.424 \mathrm{E}+04$ \\
\hline 40.00 & $2.892 \mathrm{E}+04$ & $3.341 \mathrm{E}+04$ & $3.796 \mathrm{E}+04$ & $4.255 \mathrm{E}+04$ & $3.952 \mathrm{E}+04$ & $4.527 \mathrm{E}+04$ & $5.105 \mathrm{E}+04$ & $5.682 \mathrm{E}+04$ & $3.212 \mathrm{E}+04$ & $3.744 \mathrm{E}+04$ & $4.287 \mathrm{E}+04$ & $4.833 E+04$ \\
\hline 60.00 & $2.377 \mathrm{E}+04$ & $2.753 \mathrm{E}+04$ & $3.136 \mathrm{E}+04$ & $3.521 \mathrm{E}+04$ & $3.400 \mathrm{E}+04$ & $3.895 \mathrm{E}+04$ & $4.392 \mathrm{E}+04$ & $4.888 \mathrm{E}+04$ & $2.706 \mathrm{E}+04$ & $3.159 \mathrm{E}+04$ & $3.622 \mathrm{E}+04$ & $4.088 \mathrm{E}+04$ \\
\hline 80.00 & $2.056 \mathrm{E}+04$ & $2.387 \mathrm{E}+04$ & $2.726 \mathrm{E}+04$ & $3.067 \mathrm{E}+04$ & $3.033 \mathrm{E}+04$ & $3.476 \mathrm{E}+04$ & $3.921 \mathrm{E}+04$ & $4.365 \mathrm{E}+04$ & $2.384 \mathrm{E}+04$ & $2.787 \mathrm{E}+04$ & $3.199 \mathrm{E}+04$ & $3.614 \mathrm{E}+04$ \\
\hline
\end{tabular}


Table B2. Decay heat data as a function of time after shutdown for BWR fuel (continued)

\begin{tabular}{|c|c|c|c|c|c|c|c|c|c|c|c|c|}
\hline \multirow{2}{*}{ Time } & \multicolumn{4}{|c|}{ UOX } & \multicolumn{4}{|c|}{ RG-MOX } & \multicolumn{4}{|c|}{ WG-MOX } \\
\hline & 35 GWd & 40 GWd & 45 GWd & 50 GWd & 35 GWd & 40 GWd & 45 GWd & 50 GWd & 35 GWd & 40 GWd & 45 GWd & 50 GWd \\
\hline 100.00 & $1.824 \mathrm{E}+04$ & $2.123 \mathrm{E}+04$ & $2.430 \mathrm{E}+04$ & $2.740 \mathrm{E}+04$ & $2.755 \mathrm{E}+04$ & $3.158 \mathrm{E}+04$ & $3.564 \mathrm{E}+04$ & $3.969 \mathrm{E}+04$ & $2.146 \mathrm{E}+04$ & $2.512 \mathrm{E}+04$ & $2.887 \mathrm{E}+04$ & $3.265 \mathrm{E}+04$ \\
\hline 120.00 & $1.641 \mathrm{E}+04$ & $1.915 \mathrm{E}+04$ & $2.197 \mathrm{E}+04$ & $2.483 \mathrm{E}+04$ & $2.527 \mathrm{E}+04$ & $2.898 \mathrm{E}+04$ & $3.272 \mathrm{E}+04$ & $3.646 \mathrm{E}+04$ & $1.956 \mathrm{E}+04$ & $2.292 \mathrm{E}+04$ & $2.637 \mathrm{E}+04$ & $2.985 \mathrm{E}+04$ \\
\hline 140.00 & $1.492 \mathrm{E}+04$ & $1.745 \mathrm{E}+04$ & $2.006 \mathrm{E}+04$ & $2.273 \mathrm{E}+04$ & $2.334 \mathrm{E}+04$ & $2.678 \mathrm{E}+04$ & $3.025 \mathrm{E}+04$ & $3.372 \mathrm{E}+04$ & $1.798 \mathrm{E}+04$ & $2.109 \mathrm{E}+04$ & $2.428 \mathrm{E}+04$ & $2.751 \mathrm{E}+04$ \\
\hline 170.00 & $1.312 \mathrm{E}+04$ & $1.539 \mathrm{E}+04$ & $1.775 \mathrm{E}+04$ & $2.017 \mathrm{E}+04$ & $2.092 \mathrm{E}+04$ & $2.401 \mathrm{E}+04$ & $2.714 \mathrm{E}+04$ & $3.028 \mathrm{E}+04$ & $1.603 \mathrm{E}+04$ & $1.882 \mathrm{E}+04$ & $2.170 \mathrm{E}+04$ & $2.462 \mathrm{E}+04$ \\
\hline 200.00 & $1.170 \mathrm{E}+04$ & $1.378 \mathrm{E}+04$ & $1.593 \mathrm{E}+04$ & $1.815 \mathrm{E}+04$ & $1.893 \mathrm{E}+04$ & $2.174 \mathrm{E}+04$ & $2.459 \mathrm{E}+04$ & $2.744 \mathrm{E}+04$ & $1.446 \mathrm{E}+04$ & $1.699 \mathrm{E}+04$ & $1.961 \mathrm{E}+04$ & $2.227 \mathrm{E}+04$ \\
\hline 230.00 & $1.057 \mathrm{E}+04$ & $1.248 \mathrm{E}+04$ & $1.446 \mathrm{E}+04$ & $1.652 \mathrm{E}+04$ & $1.726 \mathrm{E}+04$ & $1.984 \mathrm{E}+04$ & $2.245 \mathrm{E}+04$ & $2.507 \mathrm{E}+04$ & $1.316 \mathrm{E}+04$ & $1.548 \mathrm{E}+04$ & $1.788 \mathrm{E}+04$ & $2.032 \mathrm{E}+04$ \\
\hline 260.00 & $9.649 \mathrm{E}+03$ & $1.141 \mathrm{E}+04$ & $1.326 \mathrm{E}+04$ & $1.517 \mathrm{E}+04$ & $1.585 \mathrm{E}+04$ & $1.822 \mathrm{E}+04$ & $2.063 \mathrm{E}+04$ & $2.306 \mathrm{E}+04$ & $1.207 \mathrm{E}+04$ & $1.421 \mathrm{E}+04$ & $1.642 \mathrm{E}+04$ & $1.868 \mathrm{E}+04$ \\
\hline 300.00 & $8.658 \mathrm{E}+03$ & $1.026 \mathrm{E}+04$ & $1.195 \mathrm{E}+04$ & $1.371 \mathrm{E}+04$ & $1.427 \mathrm{E}+04$ & $1.641 \mathrm{E}+04$ & $1.859 \mathrm{E}+04$ & $2.080 \mathrm{E}+04$ & $1.087 \mathrm{E}+04$ & $1.280 \mathrm{E}+04$ & $1.480 \mathrm{E}+04$ & $1.685 \mathrm{E}+04$ \\
\hline 400.00 & $6.923 \mathrm{E}+03$ & $8.239 \mathrm{E}+03$ & $9.633 \mathrm{E}+03$ & $1.109 \mathrm{E}+04$ & $1.135 \mathrm{E}+04$ & $1.307 \mathrm{E}+04$ & $1.483 \mathrm{E}+04$ & $1.661 \mathrm{E}+04$ & $8.658 \mathrm{E}+03$ & $1.020 \mathrm{E}+04$ & $1.181 \mathrm{E}+04$ & $1.347 \mathrm{E}+04$ \\
\hline 500.00 & $5.767 \mathrm{E}+03$ & $6.878 \mathrm{E}+03$ & $8.061 \mathrm{E}+03$ & $9.308 \mathrm{E}+03$ & $9.355 \mathrm{E}+03$ & $1.078 \mathrm{E}+04$ & $1.224 \mathrm{E}+04$ & $1.373 \mathrm{E}+04$ & $7.128 \mathrm{E}+03$ & $8.401 \mathrm{E}+03$ & $9.734 \mathrm{E}+03$ & $1.111 \mathrm{E}+04$ \\
\hline 600.00 & $4.919 \mathrm{E}+03$ & $5.874 \mathrm{E}+03$ & $6.896 \mathrm{E}+03$ & $7.977 \mathrm{E}+03$ & $7.914 \mathrm{E}+03$ & $9.118 \mathrm{E}+03$ & $1.036 \mathrm{E}+04$ & $1.164 \mathrm{E}+04$ & $5.995 \mathrm{E}+03$ & $7.067 \mathrm{E}+03$ & $8.195 E+03$ & $9.367 \mathrm{E}+03$ \\
\hline 700.00 & $4.262 \mathrm{E}+03$ & $5.095 \mathrm{E}+03$ & $5.989 \mathrm{E}+03$ & $6.938 \mathrm{E}+03$ & $6.840 \mathrm{E}+03$ & $7.880 \mathrm{E}+03$ & $8.959 \mathrm{E}+03$ & $1.007 \mathrm{E}+04$ & $5.123 \mathrm{E}+03$ & $6.042 \mathrm{E}+03$ & $7.013 \mathrm{E}+03$ & $8.025 \mathrm{E}+03$ \\
\hline 800.00 & $3.741 \mathrm{E}+03$ & $4.475 \mathrm{E}+03$ & $5.265 \mathrm{E}+03$ & $6.108 \mathrm{E}+03$ & $6.022 \mathrm{E}+03$ & $6.935 \mathrm{E}+03$ & $7.884 \mathrm{E}+03$ & $8.864 \mathrm{E}+03$ & $4.439 \mathrm{E}+03$ & $5.237 \mathrm{E}+03$ & $6.084 \mathrm{E}+03$ & $6.970 \mathrm{E}+03$ \\
\hline 900.00 & $3.320 \mathrm{E}+03$ & $3.974 \mathrm{E}+03$ & $4.680 \mathrm{E}+03$ & $5.434 \mathrm{E}+03$ & $5.388 \mathrm{E}+03$ & $6.201 \mathrm{E}+03$ & $7.048 \mathrm{E}+03$ & $7.925 \mathrm{E}+03$ & $3.893 \mathrm{E}+03$ & $4.596 \mathrm{E}+03$ & $5.344 \mathrm{E}+03$ & $6.129 E+03$ \\
\hline 1100.00 & $2.698 \mathrm{E}+03$ & $3.231 \mathrm{E}+03$ & $3.807 \mathrm{E}+03$ & $4.427 \mathrm{E}+03$ & $4.495 \mathrm{E}+03$ & $5.163 \mathrm{E}+03$ & $5.863 \mathrm{E}+03$ & $6.588 \mathrm{E}+03$ & $3.098 \mathrm{E}+03$ & $3.662 \mathrm{E}+03$ & $4.264 \mathrm{E}+03$ & $4.900 \mathrm{E}+03$ \\
\hline 1200.00 & $2.468 \mathrm{E}+03$ & $2.954 \mathrm{E}+03$ & $3.481 \mathrm{E}+03$ & $4.049 \mathrm{E}+03$ & $4.179 \mathrm{E}+03$ & $4.793 \mathrm{E}+03$ & $5.438 \mathrm{E}+03$ & $6.108 \mathrm{E}+03$ & $2.808 \mathrm{E}+03$ & $3.319 \mathrm{E}+03$ & $3.867 \mathrm{E}+03$ & $4.448 \mathrm{E}+03$ \\
\hline 1300.00 & $2.276 \mathrm{E}+03$ & $2.724 \mathrm{E}+03$ & $3.210 \mathrm{E}+03$ & $3.734 \mathrm{E}+03$ & $3.923 \mathrm{E}+03$ & $4.493 \mathrm{E}+03$ & $5.092 \mathrm{E}+03$ & $5.715 \mathrm{E}+03$ & $2.569 \mathrm{E}+03$ & $3.038 \mathrm{E}+03$ & $3.541 \mathrm{E}+03$ & $4.075 \mathrm{E}+03$ \\
\hline 1500.00 & $1.983 \mathrm{E}+03$ & $2.370 \mathrm{E}+03$ & $2.790 \mathrm{E}+03$ & $3.245 \mathrm{E}+03$ & $3.541 \mathrm{E}+03$ & $4.044 \mathrm{E}+03$ & $4.573 \mathrm{E}+03$ & $5.124 \mathrm{E}+03$ & $2.208 \mathrm{E}+03$ & $2.611 \mathrm{E}+03$ & $3.044 \mathrm{E}+03$ & $3.506 \mathrm{E}+03$ \\
\hline 1700.00 & $1.775 \mathrm{E}+03$ & $2.117 \mathrm{E}+03$ & $2.490 \mathrm{E}+03$ & $2.893 \mathrm{E}+03$ & $3.280 \mathrm{E}+03$ & $3.734 \mathrm{E}+03$ & $4.212 \mathrm{E}+03$ & $4.709 \mathrm{E}+03$ & $1.957 \mathrm{E}+03$ & $2.312 \mathrm{E}+03$ & $2.695 \mathrm{E}+03$ & $3.103 \mathrm{E}+03$ \\
\hline 1900.00 & $1.624 \mathrm{E}+03$ & $1.933 \mathrm{E}+03$ & $2.269 \mathrm{E}+03$ & $2.633 \mathrm{E}+03$ & $3.096 \mathrm{E}+03$ & $3.514 \mathrm{E}+03$ & $3.953 \mathrm{E}+03$ & $4.410 \mathrm{E}+03$ & $1.779 \mathrm{E}+03$ & $2.099 \mathrm{E}+03$ & $2.444 \mathrm{E}+03$ & $2.813 \mathrm{E}+03$ \\
\hline 2100.00 & $1.511 \mathrm{E}+03$ & $1.795 \mathrm{E}+03$ & $2.103 \mathrm{E}+03$ & $2.437 \mathrm{E}+03$ & $2.964 \mathrm{E}+03$ & $3.353 \mathrm{E}+03$ & $3.763 \mathrm{E}+03$ & $4.189 \mathrm{E}+03$ & $1.650 \mathrm{E}+03$ & $1.943 \mathrm{E}+03$ & $2.260 \mathrm{E}+03$ & $2.598 \mathrm{E}+03$ \\
\hline 2300.00 & $1.425 \mathrm{E}+03$ & $1.689 \mathrm{E}+03$ & $1.975 \mathrm{E}+03$ & $2.285 \mathrm{E}+03$ & $2.866 \mathrm{E}+03$ & $3.233 \mathrm{E}+03$ & $3.619 \mathrm{E}+03$ & $4.021 \mathrm{E}+03$ & $1.556 \mathrm{E}+03$ & $1.828 \mathrm{E}+03$ & $2.122 \mathrm{E}+03$ & $2.437 \mathrm{E}+03$ \\
\hline 2500.00 & $1.358 \mathrm{E}+03$ & $1.606 \mathrm{E}+03$ & $1.875 \mathrm{E}+03$ & $2.166 \mathrm{E}+03$ & $2.792 \mathrm{E}+03$ & $3.142 \mathrm{E}+03$ & $3.509 \mathrm{E}+03$ & $3.890 \mathrm{E}+03$ & $1.485 \mathrm{E}+03$ & $1.741 \mathrm{E}+03$ & $2.018 \mathrm{E}+03$ & $2.313 \mathrm{E}+03$ \\
\hline 2700.00 & $1.304 \mathrm{E}+03$ & $1.539 \mathrm{E}+03$ & $1.794 \mathrm{E}+03$ & $2.070 \mathrm{E}+03$ & $2.735 \mathrm{E}+03$ & $3.070 \mathrm{E}+03$ & $3.421 \mathrm{E}+03$ & $3.785 \mathrm{E}+03$ & $1.431 \mathrm{E}+03$ & $1.674 \mathrm{E}+03$ & $1.936 \mathrm{E}+03$ & $2.216 \mathrm{E}+03$ \\
\hline
\end{tabular}


Table B2. Decay heat data as a function of time after shutdown for BWR fuel (continued)

\begin{tabular}{|c|c|c|c|c|c|c|c|c|c|c|c|c|}
\hline \multirow{2}{*}{ Time } & \multicolumn{4}{|c|}{ UOX } & \multicolumn{4}{|c|}{ RG-MOX } & \multicolumn{4}{|c|}{ WG-MOX } \\
\hline & 35 GWd & 40 GWd & 45 GWd & 50 GWd & 35 GWd & 40 GWd & 45 GWd & 50 GWd & 35 GWd & 40 GWd & 45 GWd & 50 GWd \\
\hline 2900.00 & $1.260 \mathrm{E}+03$ & $1.485 \mathrm{E}+03$ & $1.728 \mathrm{E}+03$ & $1.991 \mathrm{E}+03$ & $2.689 \mathrm{E}+03$ & $3.012 \mathrm{E}+03$ & $3.350 \mathrm{E}+03$ & $3.699 \mathrm{E}+03$ & $1.388 \mathrm{E}+03$ & $1.621 \mathrm{E}+03$ & $1.872 \mathrm{E}+03$ & $2.138 \mathrm{E}+03$ \\
\hline 3100.00 & $1.223 \mathrm{E}+03$ & $1.439 \mathrm{E}+03$ & $1.673 \mathrm{E}+03$ & $1.925 \mathrm{E}+03$ & $2.653 \mathrm{E}+03$ & $2.964 \mathrm{E}+03$ & $3.291 \mathrm{E}+03$ & $3.628 \mathrm{E}+03$ & $1.355 \mathrm{E}+03$ & $1.579 \mathrm{E}+03$ & $1.820 \mathrm{E}+03$ & $2.075 \mathrm{E}+03$ \\
\hline 3300.00 & $1.192 \mathrm{E}+03$ & $1.401 \mathrm{E}+03$ & $1.626 \mathrm{E}+03$ & $1.868 \mathrm{E}+03$ & $2.622 \mathrm{E}+03$ & $2.924 \mathrm{E}+03$ & $3.240 \mathrm{E}+03$ & $3.567 \mathrm{E}+03$ & $1.328 \mathrm{E}+03$ & $1.545 \mathrm{E}+03$ & $1.777 \mathrm{E}+03$ & $2.023 \mathrm{E}+03$ \\
\hline 3800.00 & $1.130 \mathrm{E}+03$ & $1.324 \mathrm{E}+03$ & $1.533 \mathrm{E}+03$ & $1.758 \mathrm{E}+03$ & $2.563 \mathrm{E}+03$ & $2.846 \mathrm{E}+03$ & $3.141 \mathrm{E}+03$ & $3.445 \mathrm{E}+03$ & $1.279 \mathrm{E}+03$ & $1.481 \mathrm{E}+03$ & $1.697 \mathrm{E}+03$ & $1.924 \mathrm{E}+03$ \\
\hline 4300.00 & $1.082 \mathrm{E}+03$ & $1.266 \mathrm{E}+03$ & $1.463 \mathrm{E}+03$ & $1.674 \mathrm{E}+03$ & $2.520 \mathrm{E}+03$ & $2.787 \mathrm{E}+03$ & $3.065 \mathrm{E}+03$ & $3.350 \mathrm{E}+03$ & $1.246 \mathrm{E}+03$ & $1.437 \mathrm{E}+03$ & $1.640 \mathrm{E}+03$ & $1.854 \mathrm{E}+03$ \\
\hline 4800.00 & $1.043 \mathrm{E}+03$ & $1.218 \mathrm{E}+03$ & $1.406 \mathrm{E}+03$ & $1.606 \mathrm{E}+03$ & $2.484 \mathrm{E}+03$ & $2.738 \mathrm{E}+03$ & $3.002 \mathrm{E}+03$ & $3.272 \mathrm{E}+03$ & $1.221 \mathrm{E}+03$ & $1.404 \mathrm{E}+03$ & $1.597 \mathrm{E}+03$ & $1.799 \mathrm{E}+03$ \\
\hline 5300.00 & $1.009 \mathrm{E}+03$ & $1.178 \mathrm{E}+03$ & $1.357 \mathrm{E}+03$ & $1.549 \mathrm{E}+03$ & $2.453 \mathrm{E}+03$ & $2.696 \mathrm{E}+03$ & $2.946 \mathrm{E}+03$ & $3.202 \mathrm{E}+03$ & $1.201 \mathrm{E}+03$ & $1.377 \mathrm{E}+03$ & $1.562 \mathrm{E}+03$ & $1.754 \mathrm{E}+03$ \\
\hline 5800.00 & $9.790 \mathrm{E}+02$ & $1.142 \mathrm{E}+03$ & $1.314 \mathrm{E}+03$ & $1.499 \mathrm{E}+03$ & $2.425 \mathrm{E}+03$ & $2.657 \mathrm{E}+03$ & $2.896 \mathrm{E}+03$ & $3.140 \mathrm{E}+03$ & $1.184 \mathrm{E}+03$ & $1.354 \mathrm{E}+03$ & $1.531 \mathrm{E}+03$ & $1.715 \mathrm{E}+03$ \\
\hline 6300.00 & $9.515 \mathrm{E}+02$ & $1.109 \mathrm{E}+03$ & $1.276 \mathrm{E}+03$ & $1.453 \mathrm{E}+03$ & $2.399 \mathrm{E}+03$ & $2.621 \mathrm{E}+03$ & $2.849 \mathrm{E}+03$ & $3.082 \mathrm{E}+03$ & $1.169 \mathrm{E}+03$ & $1.333 \mathrm{E}+03$ & $1.504 \mathrm{E}+03$ & $1.680 \mathrm{E}+03$ \\
\hline 6800.00 & $9.258 \mathrm{E}+02$ & $1.078 \mathrm{E}+03$ & $1.240 \mathrm{E}+03$ & $1.411 \mathrm{E}+03$ & $2.374 \mathrm{E}+03$ & $2.587 \mathrm{E}+03$ & $2.805 \mathrm{E}+03$ & $3.027 \mathrm{E}+03$ & $1.155 \mathrm{E}+03$ & $1.315 \mathrm{E}+03$ & $1.479 \mathrm{E}+03$ & $1.649 \mathrm{E}+03$ \\
\hline 7300.00 & $9.016 \mathrm{E}+02$ & $1.050 \mathrm{E}+03$ & $1.206 \mathrm{E}+03$ & $1.371 \mathrm{E}+03$ & $2.350 \mathrm{E}+03$ & $2.554 \mathrm{E}+03$ & $2.764 \mathrm{E}+03$ & $2.976 \mathrm{E}+03$ & $1.142 \mathrm{E}+03$ & $1.297 \mathrm{E}+03$ & $1.456 \mathrm{E}+03$ & $1.619 \mathrm{E}+03$ \\
\hline 7800.00 & $8.786 \mathrm{E}+02$ & $1.022 \mathrm{E}+03$ & $1.174 \mathrm{E}+03$ & $1.334 \mathrm{E}+03$ & $2.326 \mathrm{E}+03$ & $2.523 \mathrm{E}+03$ & $2.724 \mathrm{E}+03$ & $2.926 \mathrm{E}+03$ & $1.129 \mathrm{E}+03$ & $1.280 \mathrm{E}+03$ & $1.434 \mathrm{E}+03$ & $1.591 \mathrm{E}+03$ \\
\hline 8300.00 & $8.565 \mathrm{E}+02$ & $9.964 \mathrm{E}+02$ & $1.144 \mathrm{E}+03$ & $1.298 \mathrm{E}+03$ & $2.304 \mathrm{E}+03$ & $2.493 \mathrm{E}+03$ & $2.685 \mathrm{E}+03$ & $2.879 \mathrm{E}+03$ & $1.117 \mathrm{E}+03$ & $1.264 \mathrm{E}+03$ & $1.413 \mathrm{E}+03$ & $1.564 \mathrm{E}+03$ \\
\hline 9300.00 & $8.149 \mathrm{E}+02$ & $9.475 \mathrm{E}+02$ & $1.086 \mathrm{E}+03$ & $1.231 \mathrm{E}+03$ & $2.259 \mathrm{E}+03$ & $2.434 \mathrm{E}+03$ & $2.612 \mathrm{E}+03$ & $2.789 \mathrm{E}+03$ & $1.094 \mathrm{E}+03$ & $1.233 \mathrm{E}+03$ & $1.373 \mathrm{E}+03$ & $1.514 \mathrm{E}+03$ \\
\hline 10300.00 & $7.762 \mathrm{E}+02$ & $9.020 \mathrm{E}+02$ & $1.033 \mathrm{E}+03$ & $1.170 \mathrm{E}+03$ & $2.217 \mathrm{E}+03$ & $2.379 \mathrm{E}+03$ & $2.543 \mathrm{E}+03$ & $2.706 \mathrm{E}+03$ & $1.071 \mathrm{E}+03$ & $1.204 \mathrm{E}+03$ & $1.336 \mathrm{E}+03$ & $1.467 \mathrm{E}+03$ \\
\hline 11300.00 & $7.400 \mathrm{E}+02$ & $8.595 \mathrm{E}+02$ & $9.835 \mathrm{E}+02$ & $1.112 \mathrm{E}+03$ & $2.176 \mathrm{E}+03$ & $2.327 \mathrm{E}+03$ & $2.478 \mathrm{E}+03$ & $2.628 \mathrm{E}+03$ & $1.050 \mathrm{E}+03$ & $1.176 \mathrm{E}+03$ & $1.300 \mathrm{E}+03$ & $1.423 \mathrm{E}+03$ \\
\hline 12300.00 & $7.060 \mathrm{E}+02$ & $8.196 \mathrm{E}+02$ & $9.372 \mathrm{E}+02$ & $1.058 \mathrm{E}+03$ & $2.136 \mathrm{E}+03$ & $2.277 \mathrm{E}+03$ & $2.416 \mathrm{E}+03$ & $2.554 \mathrm{E}+03$ & $1.029 \mathrm{E}+03$ & $1.149 \mathrm{E}+03$ & $1.267 \mathrm{E}+03$ & $1.381 \mathrm{E}+03$ \\
\hline 14300.00 & $6.440 \mathrm{E}+02$ & $7.472 \mathrm{E}+02$ & $8.531 \mathrm{E}+02$ & $9.613 \mathrm{E}+02$ & $2.061 \mathrm{E}+03$ & $2.183 \mathrm{E}+03$ & $2.303 E+03$ & $2.420 \mathrm{E}+03$ & $9.888 \mathrm{E}+02$ & $1.099 \mathrm{E}+03$ & $1.204 \mathrm{E}+03$ & $1.305 \mathrm{E}+03$ \\
\hline 15300.00 & $6.158 \mathrm{E}+02$ & $7.143 \mathrm{E}+02$ & $8.149 \mathrm{E}+02$ & $9.174 \mathrm{E}+02$ & $2.026 \mathrm{E}+03$ & $2.140 \mathrm{E}+03$ & $2.251 \mathrm{E}+03$ & $2.359 \mathrm{E}+03$ & $9.699 \mathrm{E}+02$ & $1.075 \mathrm{E}+03$ & $1.175 \mathrm{E}+03$ & $1.269 \mathrm{E}+03$ \\
\hline 16300.00 & $5.892 \mathrm{E}+02$ & $6.833 \mathrm{E}+02$ & $7.791 \mathrm{E}+02$ & $8.761 \mathrm{E}+02$ & $1.992 \mathrm{E}+03$ & $2.098 \mathrm{E}+03$ & $2.202 \mathrm{E}+03$ & $2.302 \mathrm{E}+03$ & $9.517 \mathrm{E}+02$ & $1.053 \mathrm{E}+03$ & $1.148 \mathrm{E}+03$ & $1.236 \mathrm{E}+03$ \\
\hline 17300.00 & $5.642 \mathrm{E}+02$ & $6.541 \mathrm{E}+02$ & $7.454 \mathrm{E}+02$ & $8.375 \mathrm{E}+02$ & $1.959 \mathrm{E}+03$ & $2.059 \mathrm{E}+03$ & $2.155 \mathrm{E}+03$ & $2.247 \mathrm{E}+03$ & $9.341 \mathrm{E}+02$ & $1.031 \mathrm{E}+03$ & $1.121 \mathrm{E}+03$ & $1.205 \mathrm{E}+03$ \\
\hline 18300.00 & $5.407 \mathrm{E}+02$ & $6.267 \mathrm{E}+02$ & $7.138 \mathrm{E}+02$ & $8.012 \mathrm{E}+02$ & $1.927 \mathrm{E}+03$ & $2.021 \mathrm{E}+03$ & $2.111 \mathrm{E}+03$ & $2.196 \mathrm{E}+03$ & $9.172 \mathrm{E}+02$ & $1.010 \mathrm{E}+03$ & $1.096 \mathrm{E}+03$ & $1.175 \mathrm{E}+03$ \\
\hline 19300.00 & $5.185 E+02$ & $6.009 \mathrm{E}+02$ & $6.840 \mathrm{E}+02$ & $7.671 \mathrm{E}+02$ & $1.897 \mathrm{E}+03$ & $1.985 \mathrm{E}+03$ & $2.068 \mathrm{E}+03$ & $2.148 \mathrm{E}+03$ & $9.009 \mathrm{E}+02$ & $9.904 \mathrm{E}+02$ & $1.073 \mathrm{E}+03$ & $1.147 \mathrm{E}+03$ \\
\hline
\end{tabular}


